\title{
Legal Implications of Network Economic Effects
}

\author{
Mark A. Lemley† \& David McGowan
}

\section{TABLe of Contents}

Introduction

I. Parsing the Network Concept: Actual Networks, Virtual Networks, and Positive Feedback Effects......................... 488

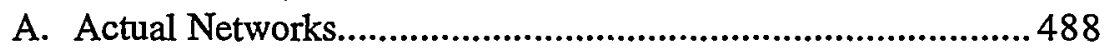

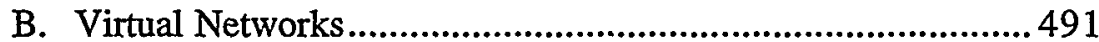

C. Positive Feedback Effects................................................... 494

D. Why We Should Care: The Possible "Effects"

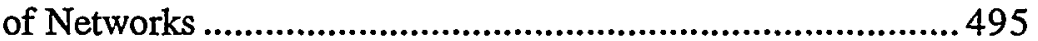

II. Network Effects as Legal Argument.........................................500

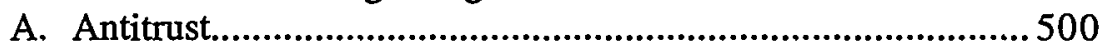

1. United States v. Microsoft...............................................500

2. ATM Networks ..........................................................507

3. Credit Card Networks.................................................512

4. Standard-Setting Organizations......................................515

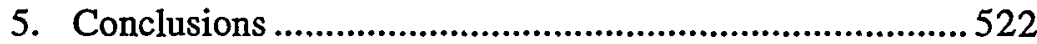

B. Intellectual Property.............................................................523

1. Arguments for Reverse Engineering..............................523

2. Arguments Against Protecting Interface

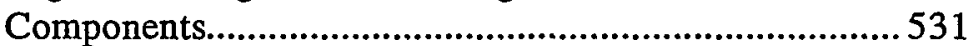

\footnotetext{
Copyright (C) 1998 Mark A. Lemley, David McGowan, and the California Law Review, Inc.

$\dagger$ Assistant Professor, University of Texas School of Law; of counsel, Fish \& Richardson P.C., Austin, Texas.

‡ Director, Howard, Rice, Nemerovski, Canady, Falk \& Rabkin, San Francisco, California. The authors would like to thank Phil Agre, David Balto, Thomas Cotter, Mel Eisenberg, Joe Farrell, Michael Froomkin, Lino Graglia, Rose Hagan, Peter Hammer, Claire Hill, Michael Klausner, Doug Laycock, Larry Lessig, Doug Lichtman, Ronald Mann, Miranda McGowan, Peter Menell, Rob Merges, Maureen O'Rourke, Mark Patterson, David Post, Jerry Reichman, Howard Shelanski, Peter Swire, and participants in workshops at the Boalt Hall School of Law, University of California at Berkeley; the University of Chicago Law School; the Chicago-Kent School of Law; the Fordham University School of Law; the Harvard Law School; the University of Michigan Law School; the University of Minnesota School of Law; the Northwestern University School of Law; the University of Pennsylvania School of Law; and the University of Texas School of Law for helpful comments on an earlier draft, Shari Heino for research assistance, and the members of the cni-copyright listserv for their engaging discussion of certain issues related to this paper.
} 
3. Compatibility as an Antitrust Issue ..............................537

4. Conclusions ..................................................................5 540

C. Government Standard-Setting ........................................541

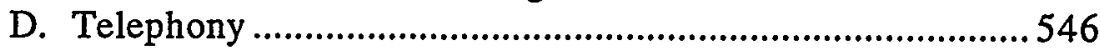

E. Internet Governance..........................................................551

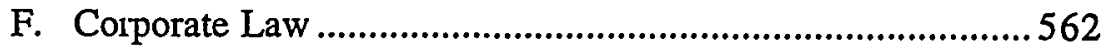

1. The Contractarian Paradigm.........................................564

2. Potential Challenges from Network Theory ....................55 565

3. Interpretive Effects.......................................................... 570

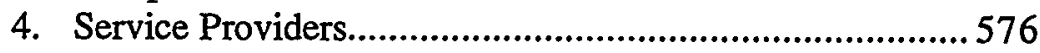

5. Marketing Effects .......................................................580

6. Implications for Corporate Governance......................... 584

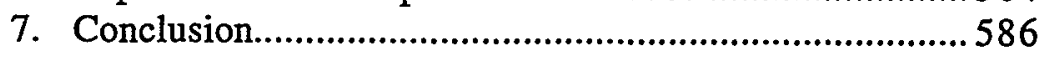

G. Contract Terms ..................................................................58

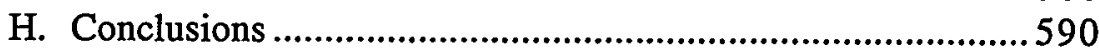

III. Deriving Principles for Judicial Treatınent of Network Effects 591

A. Nature and Strength of the Effects ..................................... 592

B. Evidence Supporting Network Effects..................................594

C. Ameliorative Effects..........................................................599

D. Significance of the Network Effect in the Industry................601

E. Importance of Existing Legal Rules ...................................602 602

F. Nature of the Relief Sought.................................................605

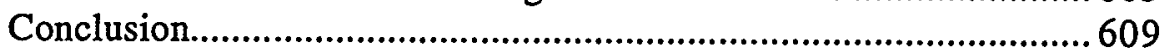




\title{
Legal Implications of Netw ork Economic Effects
}

\author{
Mark A. Lemley \& David McGowan
}

Economic scholarship has recently focused a great deal of attention on the phenomenon of network externalities, or network effects: markets in which the value that consumers place on a good increases as others use the good. Though the economic theory of network effects is of recent origin and is still not thoroughly understood, network effects increasingly play a role in legal argument. Judges, litigators, and scholars have suggested that antitrust law, intellectual property law, telecommunications law, Internet law, corporate law, and contract law need to be modified to take account of network effects. Their arguments reflect a wide range of views about what network effects are and how courts should react to them. In this Article, we explore the application of network economic theory in each of these contexts. We suggest ways in which particular legal rules should-and should not-be modifled to take account of network effects. We also attempt to draw some general conclusions about the role of network economic theory in the legal enterprise and about the way in which courts should revise legal doctrines in response to theories from fields outside the law.

\section{INTRODUCTION}

As law continues to decline as an "autonomous discipline,"l legal doctrines continue to be revised in response to theories from fields outside the law. Efforts to adapt the law to such theories often occur in circumstances in which reasoning by, analogy, the bread-and-butter methodology of litigants and courts, offers little guidance. Even where useful analogies from outside the law are available, both the principle of stare decisis and confusion as to the role of the theory in the legal realm may limit the rate at which courts can integrate such theories into legal doctrine. Thus, even theories relatively uncontroversial in other fields, such as the potential procompetitive effects of vertical nonprice

1. See Richard A. Posner, The Decline of Law As an Autonomous Discipline: 1962-1987, I00 HARV. L. REV. 761 (1987) (referring to the loss of insularity that once characterized legal thought). 
restraints in industrial organization theory, often arrive relatively late to the law. ${ }^{2}$

Further, disciplines outside the law may have normative conceptions of desirable outcomes, often unacknowledged, that the law does not share. Unless the conceptual framework of the external discipline is adopted along with its theory, the law may resist adaptation even while acknowledging the soundness of the theory. Take the exainple of antitrust law. In most recent antitrust disputes, economic analysis has prevailed; even the "post-Chicago" school of antitrust analysis exphicitly takes into account inefficiencies that courts long ignored, or even encouraged. But until courts were willing to accept efficiency as $a$ (if not always the) goal of the antitrust laws, they resisted many economic conclusions, however evident those conclusions seemed to economists. ${ }^{3}$ The law of corporate governance currently poses this problem. While recent theoretical work has tended to operate from a "contractarian" paradigm, which takes as its aim the maximization of a firm's value, actual corporate statutes do not reflect such a singular focus. ${ }^{4}$

Even if there exists a reasonable consensus as to the goals of a given doctrine, the task of adapting the theory to legal doctrine is particularly challenging where the theory is relatively new and untested in its field of origin. In some cases, a new theory will pose questions that the law has not previously decided. Because these novel questions are less subject to the brake of stare decisis, judicial adaptation in these areas may be more rapid. By the same token, a theory's novelty will limit the degree to which analogy can serve as a useful method of analysis. If no prior cases meaningfully limit the range of possible decisions, there will be few prior cases from which to derive rules necessary to reach a decision.

In this Article, we exainine one important case study in the legal adaptation of a novel theory developed outside the law. The example we choose, the relatively recent appearance in the cases and legal commentary of references to "network externalities" or "network effects",

2. See Business Electronics v. Sharp Electronics, 485 U.S. 717 (1988); Continental T.V., Inc. v. GTE Sylvania, Inc., 433 U.S. 36 (1977).

3. For a discussion of the interrelationship between theory and fact in antitrust law, see Timothy J. Muris, Economics and Antitrust, 5 GEo. MASON U. L. Rev. 303 (1997).

4. The problem is compounded because governance law is state law. Despite Delaware's predominance among large firms, varying or contradictory goals of corporate governance are common. For a discussion of this issue in the context of state takeover laws, see Amanda Acquisition Corp. v. Universal Foods Corp., 877 F.2d 496 (7th Cir. 1989).

5. Liebowitz and Margolis argue that the term "network effects" should be applied to markets with increasing returns to scale and the term "network externahities" reserved for markets in which increasing returns create suboptimal conditions. See S.J. Liebowitz \& Stephen E. Margolis, Network Externality: An Uncommon Tragedy, 8 J. Econ. Persp. 133, 135 (1994) [hereinafter Liebowitz \& Margolis, Uncommon Tragedy]; see also Willianı H. Page \& John E. Lopatka, Network Externalities, in The New Palsgrave Dictionary of Law and Economics 5-6 (forthcoming 1998). This 
raises a number of important substantive and methodological questions. As we shall see, judicial adoption and application of the theory of network effects has been swift in a wide variety of disciplines. Scholars have been even more ambitious than the courts, asserting arguments based on network effects in a wide array of disciplines. ${ }^{6}$ At one level, these trends are laudable; to the extent network theory succeeds in identifying issues previously overlooked, it has at least the potential to enrich whatever legal doctrines legitimately fall within its parameters. Realizing that potential, however, will be harder than at least some conrts and commentators believe. Significant confusion remains as to what constitutes a "network effect," and how such effects should be used in the law.

"Network effects" refers to a group of theories clustered around the question whether and to what extent standard economic theory must be altered in cases in which "the ntility that a user derives from consumption of a good increases with the number of other agents consuming the good." In other words, a network effect exists where purchasers find a good more valuable as additional purchasers buy the same good. Farrell and Saloner define the term not just to apply to circumstances in which the goods purchased are identical, but also to include situations in which " one consumer's value for a good increases when another consumer has a compatible good." ${ }^{8}$ We use network effects here to include

distinction is both appropriate and important in analyzing the intersection between economic theory and the law. The term "externality" is generally reserved for those situations in which "an agent does not bear the full cost of his actions." Dennis W. Carlton \& J. Mark Klamer, The Need for Coordination Among Firms, with Special Reference to Network Industries, 50 U. CHI. L. Rev. 446, 450 n.15 (1983). Because our goal is in large part to suggest standards courts may use to distinguish cases in which external effects should modify legal analysis from cases in which such effects do not warrant modification of legal analysis, we generally refer to network effects, reserving the more suggestive term "externahity" for those situations we believe are likely to entail some form of inefficiency attributable to network characteristics. See Jules L. Coleman, MARKETS, MoRALS AND THE LAW 76 (1988) ("Externalities are inefficient external effects-social costs or benefits that result in inefficient production or nonoptimal distributions of welfare."). As Klausner notes, the term "network externalities" seems to have occupied the entire field of network theory. See Michael Klausner, Corporations, Corporate Law, and Networks of Contracts, 81 VA. L. Rev. 757, 764 n.16 (1995).

6. For an extremely broad application of both path dependence and network effects, see Douglass C. North, Institutions, Institutional Change and Economic Performance 7-8 (1990). And Nicholas Economides has collected several hundred published articles on network effects in economics. See <http://raven.stern.nyu.edu/networks/bibliof.html> (visited Dec. 11, 1997).

7. Michael L. Katz \& Carl Shapiro, Network Externalities, Competition, and Compatibility, 75 Am. Econ. Rev. 424, 424 (1985) [hereinafter Katz \& Shapiro, Network Externalities]. See also Philip H. Dybvig \& Chester S. Spatt, Adoption Externalities as Public Goods, 20 J. PuB. EcoN 231, 231-32 (1983).

8. Joseph Farrell \& Garth Saloner, Standardization, Compatibility, and Innovation, 16 RAND J. Econ 70,70 (1985). "Compatible" here means that two goods can work together, or can work with a single type of complementary good. Software is "compatible" with an operating system if it will run on that operating system; three-prong electrical plugs are compatible with three-prong outlets, but not with two-prong outlets. 
both networks of like goods and goods compatible with the network. Estimates of this value added by participation in a network are quite high; " Metcalfe's Law" asserts that for computers, the value of participation on a network grows exponentially with the size of the network.?

Network effects directly challenge an important tenet of classical economic theory, which posits declining (and eventually negative) returns to scale im most markets. ${ }^{10}$ Classical theory comes closest to addressing this problem in its treatment of natural monopolies, a designation properly reserved for cases in which the minimum efficient size of a single producer is adequate to supply the quantity demanded in a given market. ${ }^{11}$ But natural monopoly and network effects are not the same thing. The problem $m$ the case of natural monopoly is one of scale economies of supply: the marginal and average costs of production decline throughout the demand curve for a particular market. By contrast, network effects are demand-side rather than supply-side effects: the shape of the demand curve is affected by existing demand. Economists long believed that natural monopolies mandated governmental intervention, most particularly in the form of price regulation. ${ }^{12}$ The case for automatic price regulation in natural monopoly markets has weakened in recent years, ${ }^{13}$ but the analytical structure remains essentially the same. Classical theory approaches most increasing returns problems as if they involve economies in the scale of production, rather than value added to existing users through increased demand. While the two problems may be difficult to distinguish in practice-and some courts may treat them the same-the two cases are analytically distinct and therefore may require different legal treatment, as we shall see..$^{14}$

That network effects exist to a greater or lesser degree in various markets is uncontroversial; whether and to what extent existing legal theories should be revised in light of this fact is not. ${ }^{15}$ While not an autonomous discipline, neither is law merely the repository of collected

9. See George Gilder, Metcalfe's Law and Legacy, ForBes ASAP, Sept. 13, 1993, at S158. We are unaware of any effort to measure this effect rigorously, and we find it highly unlikely that Metcalfe's Law in fact holds strictly true. Nonetheless, there is clearly something to the idea that social value increases with adoption from some goods.

10. See, e.g., Robert S. PindycK \& Daniel L. Rubinfeld, Microeconomics 187 (3d ed. 1995) (distinguishing among industries subject to increasing, constant, and decreasing returns to scale and noting that the latter category "is likely to apply to any firm with large-scale operations").

11. See, e.g., FM. Scherer, Industrial MARKet Structure AND Economic Performance 482 (2d ed. 1980); Pindyck \& Rubinfeld, supra note 10, at 352; David McGowan, Regulating Competition in the Information Age: Computer Software as an Essential Facility under the Sherman Act, 18 Hastings CoMm. \& ENT. LJ.771, 782-83 (1996).

12. See, e.g., PINDYCK \& RUBINFELD, supra note 10 , at 352 .

13. See generally Richard J. Pierce JR., Economic Regulation: Cases and Materials (1994).

14. See infra notes $482-488$.

15. See infra notes $480-526$ and accompanying text. 
abstractions from whatever disciplines might be implicated by a particular issue. Whether through litigation or legislation, the law must actively set a goal and devise a plan for achieving it, drawing upon whatever learning is useful in the endeavor. This requires the resolution of concrete disputes among parties with real-world interests. From a legal perspective, therefore, the question presented by network theories is whether we should think differently about fields such as antitrust, corporations, copyright, or contracts to the extent they seek to regulate the behavior of participants in network markets. The question must be decided as much by reference to the concerns already embodied in the theories and doctrines of these fields as by reference to new insights generated by network theory.

Like most interesting questions, those presented by efforts to adapt network theory to the law are interesting precisely because they are difficult. The theoretical implications of network markets have not been fully elaborated even in the economic literature. ${ }^{16}$ The theoretical legal analysis that has drawn upon such literature is even less complete, and empirical data on the behavior of firms and consumers in network markets is scarcer still. ${ }^{17}$ Nevertheless, the law often cannot wait for adequate theoretical development, much less firm empirical conclusions. Actual disputes among actual parties must be resolved, and courts should be encouraged to draw upon such insights as are available, even if they are not fully developed. Indeed, given the necessity of resolving disputes, the law is as often a source of data as it is a product. ${ }^{18}$

In this Article, we treat in an integrated fashion the adoption of network effects theories in seven separate fields of law. Given this broad focus, our primary aim is not conclusively to resolve doctrinal disputes in each of those areas, though we do offer some views in each area based on the present state of the evidence. Rather, our purpose in looking beyond any single set of legal rules is to attempt to offer insight into how network effects should be treated in law, and, by implication, how the law can integrate outside theories and evidence. ${ }^{19}$ Part I briefly recounts the evolution and current state of the theory of network effects in the economic literature. Part II traces the growing use of the theory in

16. See Liebowitz \& Margolis, Uncommon Tragedy, supra note 5, at 149 ("[T]he a priori case for network externalities is treacherous and the empirical case is yet to be presented.").

17. See id.; see also Klausner, supra note 5, at 851 (suggesting that theoretical case for network effects in corporate law is strong but that "[t]he pervasiveness and magnitude of these network externalities are empirical issues that must be addressed in future work").

18. See Oliver Williamson, Book Review, 77 Callf. L. Rev. 223, 228 (1989) (reviewing R. H. COASE, The FrRM, THe MARKET, AND THE LAw (1988)) (noting that Coase drew many of his examples from judicial opinions, which recognized the reciprocal nature of many problems before economists did).

19. For other attempts along these lines, see Thomas S. Ulen, Firmly Grounded: Economics in the Future of Law, 1997 W1s. L. REv. 433. 
the law, with particular emphasis on intellectual property, antitrust, corporate law, and contract. ${ }^{20}$ Part III draws together the seemingly disparate strands of network theory embodied in the cases and commentary and offers some general standards for adapting network theory to the law.

This analysis is designed to isolate the legally salient aspects of network effects theory that exist apart from particular legal applications and to suggest indicia that courts and legislatures inay use in applying network effects theory to legal issues. Specifically, we draw the following conclusious, elaborated in more detail in Part II:

- Law is perhaps uniquely susceptible to fads imported from other doctrines. Because case law is the product of an adversarial process, counsel tend to push new theories as far as possible, perhaps beyond the premises of the theory, and sometimes without regard to whether the theory properly applies to the case in the first place. Although opposing counsel will have incentive to counter such argninents, it is unrealistic to expect judges, by definition busy generalists, to discern the wheat from the chaff. ${ }^{21}$ Nor, with due respect for the significant advances in legal scholarship as the law has becoine less autonomous, is the academy immune from the occasioual tendency to take new theories to excess. Scholars may test the outer boundaries of a theory with fewer potentially adverse consequences than courts and, if for uo other reason, it is desirable that they do. By the same token, academics' work should be closely examined so that courts and legislatures will have the benefit of a full dialogne. It is in this spirit that we pursue much of what follows below. The diffusion of network economic theory into law has been fast and furious. While law cannot and should not ignore learning from other disciplines, there are risks associated with uncritically adopting network theory-or any other theory-without a careful evaluation of both the theory and the facts. Some of the examples we offer highlight this problem.

- Network effects are complex, differentiated, and often indeterminate economic phenomena, and thus are not well-suited to either fast or furious adaptation. It is impossible to speak meaningfully about the "implications" of network effects without recognizing the differing factual, economic, and legal contexts in which the theory is raised. To cite only one example, certain market conditions, such as a credible market commitunent to open standards and compatibility, may ameliorate otherwise

20. Other legal fields in which network effects have played a role include telecommunications, Internet law, government standard-setting, and even racial discrimination.

21. This is particularly true for trial judges, whose discretion is relatively limited and whose dockets require more attention than appellate judges. 
negative consequences of network effects. To the extent courts or commentators attempt to generalize about network effects or to reason by analogy without a deep understanding of how network economics work, they risk doing more harm than good. Several of the probleins in Part II result froin failure to understand network effects or their consequences. Further, some of the arguments we will consider are simply not as strong as others; they work better as models than as mandates for change in the law.

- As with any theory from outside the law, simply understanding network effects will not necessarily, or even very often, dictate a result in a particular field of law. As with economics generally, network theory inay inform courts and legislators of certain aspects of economic reality, but how the law reacts to that reality will depend on the goals of a particular legal doctrine. Where those goals are unsettled or poorly understood, as historically was the case in antitrust, ${ }^{22}$ all the economic sophistication in the world will not prevent courts froin going astray. And even where legal goals are fully understood, they may simply be incommensurate with economic theory.

- Finally, in those circumstances in which conrts or legislatures have correctly identified problems resulting froin network effects, they will often have at their disposal a variety of different remedies. We suggest that the appropriate legal accommodation of network effects is the one that least intrudes on existing legal doctrine. In soine cases, that may inean doing nothing, especially where the network inarket structure is either socially optimal or likely to be self-correcting. In other cases, to the extent possible within the confines of our adversary systein, courts should seek to solve network problems using the narrowest possible legal theory. Where a party presents a network argument in support of a very strong claim (say for violation of the antitrust laws), and the network aspect of the problem conld be solved through a more tailored approach (say by adopting an imformation-forcing rule in contract law), society may be better served by choosing the narrower doctrine and refusing to endorse a network-based theory with broader implications than necessary. ${ }^{23}$

22. Compare Richard A. Posner, Antitrust LAw: AN Economic Perspective (1976) (antitrust law is primarily concerned with promoting social welfare), with Robert Lande, Wealth Transfers as the Original and Primary Concern of Antitrust: The Efficiency Interpretation Challenged, 34 HASTINGS L.J. 65 (1982).

23. One of us has suggested that this principle would lead to a different outcome in Eastman Kodak Co. v. Image Technical Servs., 504 U.S. 451 (1992). See McGowan, supra note 11, at 840-41. 
To explain the reasoning behind these conclusions, it is necessary first to describe the theory of network effects and how it applies in the legal world. It is to this endeavor that we now turn.

I

Parsing the Network Concept: Actual Networks, Virtual Networks, and Positive FeEdback EFFects

"This is not fringe economics anymore. It's mainstream."

Garth Saloner ${ }^{24}$

Many things may increase im value as the number of users increases. The term network effects therefore must be used with great care, for it has been used to describe a number of distinct conditions in which value may increase with consumption. The state of both theoretical development and empirical research varies, and the confidence with which the law uses network theory as a basis for modifying or extending existing doctrine should be calibrated accordingly. Following Katz and Shapiro, we view network markets as falling on a continuum that may roughly be divided into actual networks, virtual networks, and simple positive feedback phenomena. ${ }^{25}$ The essential criterion for locating a good along this continuum is the degree to which the good provides inherent value to a consumer apart from any network characteristics. The greater the inherent value of the good relative to any value added by additional consumers, the less significant the network effect.

\section{A. Actual Networks}

The archetypal examples of network markets involve products whose entire value lies im facilitating interactions between a consumer and others who own the product. The benefit to a purchaser, in other words, is access to other purchasers. Telephones and fax machines are classic examples of actual network goods; owning the only telephone or fax machine in the world would be of little benefit because it could not be used to communicate with anyone. The value of the telephone or fax machime one has already purchased increases with each additional pur-

24. James Daly, The Robin Hood of the Rich, WIRED, Aug. 1997, at 108, 112 (quoting economist Garth Saloner).

25. See Katz \& Shapiro, Network Externalities, supra note 7, at 424 (distinguishing beween "direct" and "indirect" network effects, and further discussing positive consumption externalities that may arise in markets relating to durable goods). In a later article Katz and Shapiro adopt the term "virtual networks" for the second category, and we follow that terminology here. See Michael L. Katz \& Carl Shapiro, Systems Competition and Network Effects, 8 J. EcoN. PersP. 93, 95 (1994) [hereinafter Katz \& Shapiro, Systems Competition]. 
chaser, so long as all machines operate on the same standards and the network infrastructure is capable of processing all member communications reliably. ${ }^{26}$ In this relatively strict sense, actual networks are effectively limited to communications markets. ${ }^{27}$ The principal characteristics distinguishing such products from others discussed below are the absence of material inherent value and the necessity for common standards among goods incorporated into the uetwork. ${ }^{28}$

Even these relatively strict limitations raise difficult definitional questions. Language, for example, is the fundamental medium of communication and could be said to have both negligible inherent value to the first speaker and increasing value over the range of additioual speakers. Defined as a system of symbols conveying common meanings to the proficient, certain "languages" may resemble actual networks;", mathematics is perhaps the clearest example. The precision of mathematical terms inay provide a close analogy to actual network connections, even though no actual connection among "speakers" of mathematics ueed exist. ${ }^{30}$ Other specialized languages, such as accounting, will share at least some characteristics with actual networks, including at a minimum a need to ensure common definitions (protocols) to facilitate communication among a set of users. Languages are also hard to learn, which means that most people cannot simply learn five or ten different ones to facilitate communication. Groups of people who communicate regularly may therefore converge on a single language, or at least a small uumber of them. As we discuss below, corporate legal scholars have raised network effects arguments that are in significant part limguistic in form. ${ }^{31}$

Language, however, differs in significant respects from the telephone network. The differences highlight the important role legal rules

26. See, e.g., Katz \& Shapiro, Network Externalties, supra note 7, at 424 (using telephones as example of direct network market); Klausner, supra note 5, at 772 (same); Liebowitz \& Margolis, Uncommon Tragedy, supra note 5, at 139-40 ("The paradigmatic case for a direct network effect, if not an externality, is the network of telephone users.").

27. Katz and Shapiro, for example, limit their discussion of direct network effects to communications technologies. See Katz \& Shapiro, Network Externalities, supra note 7, at 424-25. See infra notes 288-307 and accompanying text (discussing the implications of network theory for telecommunications law). Of course, "communications technology" is not a term entirely free from doubt; for example, the Intemet has some but not all of the characteristics of a telephone network. See infra notes 308-316 and accompanying text.

28. See Klausner, supra note 5, at 772 (noting low inherent benefit of telephone equipment); Katz \& Shapiro, Network Externalities, supra note 7, at 425 (noting importance of technological compatibility).

29. See Liebowitz \& Margolis, Uncommon Tragedy, supra note 5, at 136 (treating language as a case of a "metaphorical network" in which there may be direct interaction without physical connections among network participants).

30. Indeed, the "language" of mathematics underlies the technology employed to make many actual networks function.

31. See infra notes 357-462 and accompanying text. 
of ownership play in facilitating the formation of networks. Property rights (nost importantly, the right to exclude others from a network) play a crucial role in network markets. In many potential networks, property rights created by legal rules, rather than physical laws, set the boundary conditions for the network. Actual networks such as telephone lines require capital investments in physical infrastructure. Such networks therefore may be owned: there are tangible assets to which property rights may be attached..$^{32}$ Even where the capital investment in a network is negligible, the law can establish ownership rights by fiat (in this case by awarding exclusive rights in "intellectual property"). Where the law establishes a right to exclude others from the use of a thing-as with intellectual property-it constrains the ability of consumers to move between network standards, and it gives control over access and pricing to the owner of the intellectual property embodied in the standard.

Property rights in natural languages would be difficult to conceptualize and even harder to enforce-much harder than rights in telephone lines, or even in lines of computer code..$^{33}$ It is conceivable to exclude "speakers" from using more specialized languages, ${ }^{34}$ but as a general rule the law does not confer exclusive rights over languages, either natural or artificial. Nor are there teclunical means of excluding people from using a language. Moreover, language is an extremely diverse phenomenon, subject to many cultural and geographic variables, even within the relatively rarefied realms of law or business. Outside of mathematics, the precision with which speakers of a given language will understand other speakers' use of the language is likely to be highly

32. Liebowitz and Margolis make this point as well. See Liebowitz \& Margolis, Uncommon Tragedy, supra note 5, at 135-36.

33. As Robert Ellickson rightly notes in deeming language an example of nonhierarchical coordination, "[m]illions of people have incrementally helped shape the English language into an enormously ornate and valuable institution. Those who have contributed to this achievment have acted without the help of the state or any other hierarchical coordinator." ROBERT C. ELLICKSON, ORDER Without LAW 5 (1991).

34. The district court in Lotus Dev. Corp. v. Paperback Software Int'l, 740 F. Supp. 37 (D. Mass. 1990), seemed to open the door to copyright protection of computer languages, such as that in the hierarcliy of the Lotus 1-2-3 spreadsheet, but it is unlikely that that decision remains good law after the First Circuit's holding in Lotus Dev. Corp. v. Borland Int'l, 49 F.3d 807 (1st Cir. 1995) (holding that menu command hierarchy for the Lotus 1-2-3 spreadsheet program was uncopyrightable). A recent decision in Australia extended copyright protection to a computer language. See Data Access Corp. v. Powerflex Servs. Pty., No. VG473 (Fed. Ct. Aus., Melboume 1996). Most commentators have been critical of this approach, lowever. See, e.g., Pamela Samuelson, How to Interpret the Lotus Decision; (And How Not To), Comm. ACM, Nov. 1990, at 27; Marci Hamilton \& Ted Sabety, Computer Science Concepts in Copyright Cases: The Path to a Coherent Law, 10 HARv. JL. \& TeCH. 239, 274-75 (1997); Elizabeth G. Lowry, Comment, Copyright Protection for Computer Languages: Creative Incentive or Technological Threat?, 39 EMORY LJ. 1293, 1335 (1990). In any event, it is not clear that even those few courts that would grant copyright protection to computer languages would afford the same protection to natural languages. 
variable. The extent of linguistic network effects, if any, will therefore be very difficult to determine.

\section{B. Virtual Networks}

Goods constitute virtual networks when they provide inherent value to consumers that increases with the number of additional users of identical and/or interoperable goods. Virtual network goods need not be linked to a common system as are the constituents of a communications network; very strong positive feedback effects tied to functional compatibility are sufficient. Computer software is the paradigm example..$^{35}$ Unlike telephones and fax machines, an operating system or application program will allow even a single user to perform a variety of tasks regardless whether even a single other consumer owns the software. At the same time, the value of a given program grows considerably as the number of additional purchasers increases. As more consumers adopted WordPerfect, for example, it became easier for each previous user to share files without the need for a conversion program and easier for employees to switch jobs without retraining. And as Microsoft Word has replaced WordPerfect as the word processing program of choice, it in turn gained the benefits of widespread adoption. Data sharing in this sense requires direct horizontal technological compatibility akin to that required for telephones and fax machimes to work together, but it does not require the actual connections that communications networks do. Further, the existence of conversion software may expand the network beyond a single, proprietary product.

In addition to horizontal technological compatibility, software may be subject to "increasing returns" based on positive feedback from the market in the form of complementary goods. Software developers will write more applications programs for an operating system with twothirds of the market than for a system with one-third because the operating system with the larger share will provide the biggest market for applications programs. The availability of a broader array of application programs will reinforce the popularity of an operating system, which in turn will make investment in application programs compatible with that system more desirable than investment in programs compatible with less popular systems. ${ }^{36}$ Similarly, firms that adopt relatively popular software

35. See, e.g., Katz \& Shapiro, Network Externalities, supra note 7, at 424 (noting computer software as example of what we here call virtual network goods); Farrell \& Saloner, supra note 8, at 70 (same); PINDYCK \& RUBINFELD, supra note 10, at 122 (same).

36. See, e.g., Mark A. Lemley \& David W. O'Brien, Encouraging Software Reuse, 49 STAN. L. Rev. 255, 287 (1997) (discussing network effects associated with software); McGowan, supra note 11, at 838-39 (discussing positive feedback effects relating to software); PINDYCK \& Rubinfeld, supra note 10, at 122 (same); Douglas G. Baird et AL., Game Theory AND The LAW 208-13 (1994) (computer operating systems characterized by network effects); Katz \& 
will likely.incur lower costs to train employees and will find it easier to hire productive temporary help than will firms with unpopular software. Importantly, the strength of network effects will vary depending on the type of software in question. Network effects will be materially greater for operating systems software than for applications programs, for example, ${ }^{37}$ and a proper legal analysis of network effects in software markets must account for this difference.

Of course, technology comprises only one element of virtual networks. Like actual networks, virtual networks are likely to require intricate webs of both formal and informal contracts to create the value the network delivers..$^{38}$ Bank-issued credit cards provide a good example. ${ }^{39}$ Although they might confer some utility on their own (particularly in their credit aspect), credit cards exhibit network effects because their utility increases dramatically as a network develops. As the number of merchants willing to accept a card grows, the utility of the card to consumers increases, thus likely increasing the number of consumers who will want to own the card, which in turn provides incentive for more merchants to accept the card, and so on.$^{40}$ With innovation in computer and telephone technology yielding such benefits as real-time transaction processing, including such features as fraud detection and verification of available credit, ${ }^{41}$ transactions involving bank-issued credit cards have come to resemble interactions on an actual network.

But the technological links and potential for positive returns to scale in the credit card industry cannot themselves create value without a sophisticated system of contracts, including agreement on the compensation card issuers will receive and the rules governing their conduct

Shapiro, Systems Competition, supra note 25, at 99 (predicting that consumer expectations of software availability will drive choice of hardware systems).

37. We discuss this in more detail infra notes 71-82 and accompanying text. For a good overview of the relative roles of operating systems software and applications program software, see Peter S. Menell, Tailoring Legal Protection for Computer Software, 39 STAN. L. REv. 1329, 1341-44 (1987). For a discussion of the relative strength of network effects on operating systems and application programs, see Lemley \& O'Brien, supra note 36, at 287-88. For a discussion of the potential conflicts among operating systems firms and applications firms, see infra notes 71-103 and accompanying text. $C f$. McGowan, supra note 11 , at $838-41$ (posing a structurally similar problem in the application context).

38. Which is of course not to diminish the role of contract in actual networks. As we discuss below, contract rules are central to network problems in both actual and virtual networks. Our discussion reflects the relatively greater importance of capital investment to the creation of actual networks and the at least potentially greater inportance of contracts to the constitution of virtual networks.

39. Bank-issued cards are to be distinguished from cards issued by retail merchants, such as a Nordstrom or Sears, and from proprietary cards owned by a single firm, such as American Express. See Dennis W. Carlton \& Alan S. Frankel, The Antitrust Economics of Credit Card Networks, 63 ANTITRUST L.J. 643, 646 (1995).

40. See infra notes 133-149 and accompanying text (discussing the economics of credit cards).

41. See Carlton \& Frankel, supra note 39, at 646. 
relative to the network. ${ }^{42}$ Thus, merchants will have a contractual relationship with a bank, which will to some extent be subject to the bank's contractual relationship with the credit card entity. If the merchant's bank did not issue the consumer's credit card, it in turn will have a contractual relationship with the issuing bank pursuant to which transactions may be cleared. The issuing bank will of course have a contractual relationship with the consumer. These contracts are as vital to the functioning of the credit card network as are the electronic links that facilitate transactions.

Many of these contracts are standardized by the rules of the Visa and MasterCard joint ventures. Those rules govern general network membership, such as the manner in which member banks may use the Visa and MasterCard marks, communication among member banks, and fees charged by member banks for processing transactions with one another. The rules do not specify standard terms, however, for contracts between merchants and their banks or between consumers and their banks. ${ }^{43}$ Therefore, the degree to which network theory plays a role in the legal analysis of credit card networks depends in significant part upon the legal and economic analysis of contract law, including the relative efficiency of standard contract terms versus either a joint venture or horizontal integration, and limitations on the ability to contract (such as those imposed by antitrust law).

Network markets may also implicate mformal contracts-reciprocal economic relationships that are neither sufficiently negotiated nor memorialized to be enforceable under current contract doctrine. ${ }^{44}$ Given the powerful positive feedback effects associated with complementary goods, particularly vertically interoperable goods such as operating systems and application program software, such arrangements may play as important à role in forming networks as do formal contracts. For example, a firm seeking to launch an operating system may induce applications programmers to write compatible programs by proclaiming that the operating system will be "open" to anyone seeking to achieve interoperability. The firm might render such pronouncements relatively credible by such tactics as providing application programmers advance copies of new versions of the operating system. Even if no formal agreements are negotiated, application programmers may dedicate significant capital to writing compatible software, creating potentially significant benefits to consumers. Should the originator of the operating

42. See id. at $647-48$ (discussing flow of funds among participants in credit card transactions).

43. See id. at 648 .

44. See Jeffrey N. Gordon, The Mandatory Structure of Corporate Law, 89 CoLuM. L. REv. 1549,1549 (1989) (noting economists' "conception of a 'contract' as an arrangement between two or more actors supported by reciprocal expectations and behavior"). 
system renege once it achieves a certain level of acceptance in the market, such informal understandings will become the subject of significant disputes, with potentially far-reaching legal and economic implications. ${ }^{45}$

Some types of networks warrant distinct analysis because they include aspects of both actual networks and other types of networks. The Internet, for example, presents a difficult case: communication on the Internet requires adherence to common technical protocols that, in an elemental sense, define the scope of the Internet. ${ }^{46}$ Internet users are not actually linked to one another, however. Rather, the protocols that define the "boundaries" of the Internet merely facilitate software interoperability. Further, not everyone on the Internet wants to be connected to everyone else; some would prefer that access to the Internet remain limited, or at least that they be able to shut themselves off from the masses in a private group. Nonetheless, at least a significant part of the value of the Internet itself is the fact that it enables communication among users; in this sense, it is a classic actual network with characteristics similar to the telephone. We will discuss some aspects of the Internet in more detail below; ${ }^{47}$ we raise the issue here to point out that networks need be neither entirely "actual" nor entirely "virtual."

\section{Positive Feedback Effects}

Lastly, goods may increase in value as consumption increases even where the goods are not theinselves connections to a network and do not interoperate with like (or "compatible") goods. Such goods reflect little more than the need for a given degree of demand to sustain production of the good and complementary goods and services. Where production of goods involves both fixed and marginal costs, the average fixed costs will decline as demand for the good increases, and the fixed costs are spread over a larger number of units. This is a common economic phenomenon-economies of scale. In some cases, a large population may be necessary to justify any production at all. We would intuitively expect exotic car repair shops to be more prevalent in large cities than rural towns because a mimimum concentration of car owners is required to generate sufficient demand to sustain a shop. ${ }^{48}$

Unlike actual or virtual networks, no technological compatibility, interoperability, or even contractual relationships are necessary to sustain this "network." Strictly speaking, it is not a network at all.

45. Cf. McGowan, supra note 11, at 838-41 (discussing opportunism in the application context).

46. See Mark A. Lemley, Antitrust and the Internet Standardization Problem, 28 CoNN. L. REv. 1041, 1043-45 (1996) [hereinafter Lemley, Internet Standardization].

47. See infra notes 308-352 and accompanying text.

48. See Liebowitz \& Margolis, Uncommon Tragedy, supra note 5, at 135. 
Network effects are demand-side effects-they result from the value that consumers place on owning what other consumers already own. By contrast, economies of scale are supply-side effects-they are a function of the cost of making the goods and exist (at least conceptually) regardless of positive utility payoffs among consumers. Markets characterized by economies of scale are, of course, potentially subject to material diseconomies of scale as well. If too many consumers purchase the same exotic car, it may become difficult to schedule repairs, obtain parts, and the like. Similarly, once a steel plant is used to its full capacity, expanding supply will require building a whole new plant, raising the average cost. Thus, there are definite limits in most markets to the "value" to consumers of buying whatever other consumers want. By definition, those markets do not exhibit network effects.

\section{Why We Should Care: The Possible "Effects" of Networks}

As discussed in detail and in context in the sections that follow, many of the concerns surrounding network markets are based on the presumption that such markets offer increasing returns over a very large portion of the demand curve. Outside the realm of natural monopoly, by contrast, neo-classical economics generally posits declining returns to scale and thus offers few conceptual tools to address the problems that arise when returns increase over a very large portion or even all of the demand curve. Thus, arguments based on network effects may suggest that the law must rethink the rationality of behavior considered unlikely under neoclassical theory, such as predation in antitrust jurisprudence, and address new risks not considered under models based on decliuning returns.

With respect to the behavioral issues, network markets by definition offer potentially lucrative returns to firms that can establish their own products as standards on which competition in the market, or in aftermarkets for complementary goods, will be based. ${ }^{49}$ This fact presents the possibility of material first-mover advantages: being the first seller in a market may confer an important advantage over later entrants. ${ }^{50}$ Because the returns to the standards winner will be higher than in "normal" markets, relatively risky strategies, such as predation or, at a minimum, penetration pricing, might be rational in a networks market. ${ }^{51}$

49. Stanley M. Besen \& Joseph Farrell, Choosing How to Compete: Strategies and Tactics in Standardization, 8 J, ECON. PERSP. 117, 119 (1994).

50. See id. at 122. Of course, this will not always be true. For example, the first entrant in the VCR market (often cited as a paradigm example of network effects), the Sony Betamax, lost a standards compctition to the VHS platform.

51. See Lemley, Internet Standardization, supra note 46, at $1074-75$ ("To the extent that standardization effects create a signficant barrier to entry in software markets once a market 
Increasing returns also raise questions about the possibility of effectively leveraging a monopoly from one market to another, an argnment most commonly associated with antitrust tying claims. Chicagoschool analysts have argued that leveraging is unlikely becanse a given amount of monopoly power can extract only a given amount of revenue from consumers, whether taken all in the monopolist's primary market or split between that market and some other. ${ }^{52}$ This view has been challenged even without regard to network theory, ${ }^{53}$ but the possibility of leveraging from a non-network market into a network market poses an important new challenge. ${ }^{54}$ Recent activity in the software industry also raises the possibility that markets for products that would be considered distinct under traditional antitrust analysis, ${ }^{55}$ such as Web browsers, might simply be absorbed into a network market through bnndling with a strong network product, snch as an operating system..$^{56}$ One might also rethink unfair competition law in light of the arguably greater sensitivity of network markets to public pronouncements: in a market in which the standard product is preferred, statements abont such products might carry greater weight than in other markets. ${ }^{57}$

These arguments are closely related to the idea of "tipping," a concept Katz and Shapiro summarize as being based on

[a] natural tendency toward de facto standardization, which means everyone using the same system. Because of the strong positive-feedback elements, systems markets are especially prone to 'tipping,' which is the tendency of one system to pull away from its rivals in popularity once it has gained an initial edge. ${ }^{58}$

standard has been established, they may make recoupment (and therefore predation) more likely."); Besen \& Farrell, supra note 49, at 123.

52. See, e.g., Robert H. Bork, The Antitrust Paradox: A Policy at War with Itself 372-75 (2d ed. 1993); POSNER, supra note 22, at 171-73. Indeed, even analysts outside the Chicago School have expressed skepticism for the leverage theory of tying. See, e.g., Herbert HovenKamp, Federal Antitrust Policy, The Law of Competition, and Its Practice $\$ 7.6$, at 269 (1994).

53. See Louis Kaplow, Extension of Monopoly Power Through Leveraging, 85 Colum. L. REv. SI5 (1985) (arguing that 'leveraging can enhance monopoly profits in cases involving market imperfections).

54. See Lemley, Internet Standardization, supra note 46, at 1069; Bryce J. Jones, Il \& James R. Tumer, Can an Operating System Vendor Have a Duty to Aid Its Competitors?, 37 JuRIMETRIcs J. 355,390 (I997) (suggesting that leveraging is more likely in Microsoft's OS market). Note that the argument also works in reverse: a firm with a strong position in a network market might have enhanced ability-although perhaps less desire-to leverage into a non-network market.

55. The standard test is taken froin Jefferson Parish Hosp. Dist. No. 2 v. Hyde, 466 U.S. 2, 2122 (1984), under which separate markets are deemed to exist if there is sufficient consumer demand for the products to be sold separately.

56. See Daly, supra note 24, at 109-10 (citing Netscape lawyer Gary Reback's claim that Microsoft is improperly trying to drive Netscape out of the Web browser market by incorporating its competing Web browser into new versions of its operating system). For a more detailed discussion of this allegation, see infra notes 96-105 and accompanying text.

57. See Katz \& Shapiro, Systems Competition, supra note 25, at 107.

58. Id. at $105-06$. 
Tipping is neither inherently good nor bad. If the economics of a particular market dictate that having one standard is more efficient than competition among standards, then "tipping" to one standard is in theory inevitable, absent significant transaction costs or some form of regulation. In such circumstances a "tipped" market would be efficient and therefore desirable; efforts to forestall tipping would result in suboptimal heterogeneity among systems and losses in terms of unrealized efficiencies. That a market is best served by a single standard, however, does not always imply that the standard should be owned by a single firm, or even that the standard should be owned at all.

Even in markets best served by a single standard or system, however, there is at least a theoretical risk that the "wrong" standard will be adopted or that a standard that was efficient when adopted will become relatively inefficient over time. ${ }^{59}$ The conclusion that a standard adopted by consumers is suboptimal should be approached with caution. Setting aside for the moinent the very difficult question of deriving determinative criteria for defining "suboptimality," consumers might have difficulty moving to a new standard-even if they all agreed that the adopted standard was suboptimal-because of collective action problems. The value of any alternative system would depend on the number of users adopting it; the rational consumer might well choose to wait until an alternative had been adopted by others who incurred the costs of shifting to the new standard but reaped fewer benefits relative to later adopters. $^{60}$

From the standpoint of legal adaptation of network theory, each of these arguinents is to some degree problematic. The presumed increasing returns of network markets are not guaranteed; networks will suffer net diseconomies of scale if the volume of interactions exceeds network capacity and causes delays or failure. ${ }^{61}$ Positive returns to some level of

59. See id. at 106 ("[S]tandardizing on a single system can be very costly if the system selected turns out to be inferior to another system.").

60. In addition, there are certain more abstract concerns that have as yet played a relatively small role in legal arguments. Principal among these is the risk of suboptimal network size, and thus of unexploited gains from trade, stemming from the inability of existing users to compensate prospective users for the incremental value they would add to the network by joining. Marcel Kahan and Michael Klausner have suggested in the context of corporate bonds that intermediaries such as investment banks may ameliorate such problems to some degree. See Marcel Kahan \& Michael Klausner, Standardization and Innovation in Corporate Contracting (Or, "The Economics of Boilerplate"), 83 VA. L. REv. 713, 738 (1997) [hereinafter Kahan \& Klausner, Standardization].

61. One might of course posit a rational investment strategy under which the prospect of increasing returns will induce sufficient investment to maintain the network and expand it so as to avoid such failures. For a variety of reasons, however, there is no guarantee that such a strategy would always be pursued or be properly implemented where it was pursued. It follows that there is no guarantee that returns will invariably increase over the full range of the demand curve even where market conditions make such a result most likely. 
scale are in any event quite common, if not ubiquitous. ${ }^{62}$ Further, network effects might not be the only effects at work. A user might prefer Lexis to Westlaw, but only up to a certain point. If the information she ueeds is available only on Westlaw, she may start using that service, whatever the cost in terms of lost couvenience. At a minimum, coininon sense tells us that there likely are differences material to most areas of the law between a network of telephones or fax machines and a "network" of Ferrari owners. It is thus important to analyze markets to determine the source of increasing returns-whether from actual or virtual networks - and to distinguish among markets displaying inerely positive returns to scale, inarkets displaying network effects only up to a relatively low point on the deinand curve, ${ }^{63}$ and markets displaying increasing returns over most or all of the demand curve. The ratio of inherent value to uetwork value is of similar importance.

One final feature of network theory bears siguificant einphasis. Network effects tend to have conflicting implications that are very difficult to interpret. To take corporate governance as an example, some have argued that a given corporate governance term might display network effects by gaining greater clarity of meaning over time and through repeated interpretation by courts. ${ }^{64}$ If one observes that firms all use that term, however, does that reflect maximization of positive interpretive network effects or does it reflect suboptimal tipping? Or is the term inherently the best oue? If firms use a variety of different terms on a given point, does that reflect the optimal convergence of heterogeneous firms with heterogeneous governance provisions or does it reflect opportunity costs of not using a standard term? In many cases, the observable data can lead to diametrically opposed conclusions, making the task of judicial adaptation extremely difficult.

The potentially inconsistent implications of network theory render the process of judicial adaptation difficult enough. That difficulty is inaterially compounded, however, in cases in which network arguments relate to legal fields that are themselves unsettled. The economic understanding of the potential procompetitive effects of vertical nonprice restraints entered antitrust law slowly, in large part due to a lack of consensus among courts and commentators on the proper goals of antitrust laws. A comment by Richard Posner, writing before the Chicago revolution took very firm hold in antitrust, applies to many fields of law today:

There are federal antitrust statutes, and they are quite brief and readable compared to the Internal Revenue Code. But their

62. See Liebowitz \& Margolis, Uncommon Tragedy, supra note 5, at 133-35.

63. Liebowitz \& Margolis term this "inframarginal externalities." See id. at 140.

64. See Kahan \& Klausner, Standardization, supra note 60 , at 722. 
operative terms-“restraint of trade," "substantially to lessen competition," "monopolize"-are opaque; and the congressional debates and reports that preceded their enactment, and other relevant historical materials, only dimly illuminate the intended meaning of the key terms. The courts have spent many years interpreting, or perhaps more accurately supplying, their meaning, but the course of judicial interpretation has been so marked by contradiction and ambiguity as to leave the law in an uncertain and fluid state. What is more, the rules of law as they are articulated and as they are applied to alter behavior are often, as is true in this instance, two quite different things. ${ }^{65}$

This somewhat discouraged appraisal of the state of antitrust in 1976 may be less warranted now, at least from the perspective of an economist. ${ }^{66}$ Still, many fields of law (or at least portions of them) do resemble the state of affairs Posner described. The corporate rule that defensive measures to unwanted takeover attempts must be "reasonable" and may not be "Draconian" is not a paragon of clarity, nor have the copyright statutes or the cases interpreting them shed much light on what constitutes a "fair use" of another's work. ${ }^{67}$ Such opaqueness might simply reflect a preference for ex post resolution of disputes. But in a fair number of cases, as was the case with antitrust at the time Judge Posner was writing, the law has not yet decided on a direction.

The inherent complexities and potentially inconsistent siguals of network theory are difficult but potentially surmountable problems; indecision with respect to the purpose of the law in question is not. All law is purposive, and the process of judicial adaptation requires first a rigorous analysis of the purposes the law seeks to achieve before the process of adapting network theory can begin in earnest. To the extent the legal analysis is lacking, any efforts at adaptation are unlikely to succeed and may cause a good deal of harm. With that caveat in mind,

65. POSNER, supra note 22 , at 3.

66. There is in any event greater certainty in antitrust jurisprudence today than there was twenty years ago, in large part because of the virtually unquestioned dominance of economic tools in modern antitrust analysis. See generally IVilliam H. Page, The Chicago School and the Evolution of Antitrust: Characterization, Antitrust Injury and Evidentiary Sufficiency, 75 VA. L. REv. 1221 (1989). And those economic tools have bcen refined over time beyond the basic approaches characteristic (or at least stereotypic) of the Chicago School-a refinement which has given rise to the name PostChicago Law and Economics. See Symposium on Post-Chicago Law and Economics, 65 CHI.-KENT L Rev. 3 (1989).

67. See James Boyle, Shamans, Software, and Spleens: Law and the Construction OF THE INFORMATION SOCIETY 19 (1996) ("[I]n copyright law-to a greater extent than in most other fields of legal doctrine-there is a routine and acknowledged breakdown of the simplifying assumptions of discourse, so that mundane issues force lawyers, judges and policymakers to return to first principles."). 
we turn to the instances in which network theory has been advanced as a basis for revising existing legal thought.

\section{II}

\section{NETwORK EFFECTS As Legal ARgumENT}

The economic literature on network effects has been integrated quite rapidly into legal arguinent. Courts, litigators, and a host of commentators have used claims of network effects in an effort to influence a wide variety of legal rules. In this Part, we review both the legal literature and the developing case law, focusing on a number of areas in which network effects claims seem most prevalent. What is most startling about these asserted network effects is not simply their number and variety, but the radically different uses to which the concept is put.

\section{A. Antitrust}

Network effects claims are at base arguments about market strncture, so it is not surprising that they have increasingly found their way into antitrust law. ${ }^{68}$ Strong network effects can fundamentally alter the way in which competition works and, therefore, the proper role of antitrust law in a network market. ${ }^{69}$ At the same time, network effects are not present in all cases, nor even in all cases in which advocates assert they are. Further, in some circumstances, existing antitrust doctrine already deals effectively with network effects. ${ }^{70}$ In this Section, we focus on a number of circumstances in which attorneys, judges, and legal commentators have offered network effects as a reason either to invoke antitrust law or to refram from doing so.

\section{United States v. Microsoft}

Perhaps the best known of the antitrust cases involving network effects are the Antitrust Division's monopolization and tying suit and subsequent contempt proceeding against Microsoft. ${ }^{71}$ After a lengthy investigation by both the Federal Trade Commission and the Antitrust Division, the latter filed suit against Microsoft in 1994. As is common

68. See, e.g., Joseph Kattan, Trends in Intellectual Property Antitrust Enforcement, ANTrTRusT, Summer 1997, at 26, 29 ("In recent years, antitrust analysis has increasingly focused on network effects."). For a contrary view, see Daly, supra note 24, at 108, 112 (quoting economist Garth Saloner as saying of network theory: "This is not friuge economics anymore. It's mainstream, except in antitrust, which always lags.").

69. See Lemley, Internet Standardization, supra note 46 , at 1071 (suggesting that structural antitrust enforcement will be ineffective in the presence of true networking effects).

70. See Bruce R. Snapp, Network Industries and Antitrust: A Cautionary Note, in Cutring EDGE ISSUES IN NETWORK INDUSTRIES 1 (1996).

71. See United States v. Microsoft Corp., 159 F.R.D. 318 (D.D.C. 1995), rev'd. 56 F.3d 1448 (D.C. Cir. 1995); United States v. Microsoft Corp., 980 F. Supp. 537 (D.D.C. 1997). 
practice, a proposed consent decree, worked out in advance by the parties accompanied the suit. ${ }^{22}$ The consent decree put a stop to several Microsoft practices that the Division alleged to be anticompetitive, including the use of de facto-exclusive "per processor licenses"73 and restrictive non-disclosure agreements with external software developers. The district court heard a rather unusual challenge to the consent decree by several unnamed Microsoft competitors, who were upset because the decree did not address certain kinds of allegedly anticompetitive conduct (such as "vaporware"). ${ }^{74}$ Judge Sporkin refused to approve the consent decree because he found it too narrow. ${ }^{75}$

All of the parties seeined to acknowledge the role network effects played in Microsoft's dominance of the operating systems market. ${ }^{76}$ The district court wrote:

Microsoft, the Justice Department, and a number of competitors who oppose the entry of the decree all agree that it is very difficult to enter the operating systems market. There are two main reasons for this, each of which reinforces the other. First, consumers do not want to buy PCs with an operating system that does not already have a large installed base because of their concern that there will not be a wide range of applications software available for that operating system. The second, com-

\section{See Microsoft, 159 F.R.D.at 321.}

73. The district court explained the potential anticompetitive effect of the per-processor license. See id. at 323. See also Kenneth C. Baseman et al., Microsoft Plays Hardball: The Use of Exclusionary Pricing and Technical Incompatibility to Maintain Power in Markets for Operating Systems Software, 40 ANTrTRUsT BuLL. 265, $267-68$ (1995) (criticizing Microsoft's per-processor license). But see Robert J. Levinson, Efficiency Lost?: The Microsoft Consent Decree, in THe Economics of the ANTITRust Process 175, 182-85 (Malcom B. Coate \& Andrew N. Kleit eds., 1996) (suggesting that per-processor licenses cannot be anticompetitive, because not all companies were forced to enter into them).

74. For more detail on the allegation that Microsoft promoted vaporware-software that did not exist-in an effort to deter competitive entry, see Microsoft, 159 F.R.D. at 334-36, and Robert Prentice, Vaporware: Imaginary High-Tech Products and Real Antitrust Liability in a Post-Chicago World, 57 Oнiо ST. LJ. 1163 (1996). We will return to the relevance of network effects to the vaporware claim. See infra notes $90-95$ and accompanying text.

75. See Microsoft, 159 F.R.D. at 333. The D.C. Circuit swiftly reversed that decision, but on jurisdictional grounds rather than on the merits of Judge Sporkin's antitrust concerns. See United States v. Microsoft, 56 F.3d 1448 (D.C. Cir. 1995).

76. See John E. Lopatka \& William H. Page, Microsoft, Monopolization, and Network Externalities: Some Uses and Abuses of Economic Theory in Antitrust Decision Making, 40 Antrrrust Bull. 317, 320-21 (1995); Mercer H. Hartz, Comment, Dominance and Duty in the European Union: A Look Through Microsoft Windows at the Essential Facilities Doctrine, 11 EMORY INT'L L. Rev. 189, 210-11 (1997). This is not to say that the issue is entirely free from doubt among economists. In a thought-provoking study, Timothy Bresnahan and Shane Greenstein model the analogous move from mainframe computers to client-server environments among large businesses. They reject the hypothesis that the move was delayed because of vendor lock-in effects, instead highlighting the technical difficulty of the switch. See Timothy Bresnahan \& Shane Greenstein, Technical Progress and Co-invention in Computing and in the Uses of Computers, 1996 Brookings PAPERS ON ECON. ACTIVITY 1. 
plementary reason why there are large barriers to entry into the operating systems market is that [independent software developers] do not want to spend time and money developing applications for operating systems that do not have a large installed base. They perceive that demand for that software will be low. As a result, [original equipment inanufacturers] have little incentive to license an operating system that does not have a large installed base and include it in their PCs.7

The important issue for our purposes is what antitrust law should-or indeed could-do about this phenomenon. One might argue that attributing Microsoft's monopoly position in the operating systeins market largely, if not entirely, to network effects means that Microsoft has done nothing more than coinpete aggressively in an industry prone to standardization. ${ }^{78}$ As we discuss below, ${ }^{79}$ it is not at all clear that the optimal number of operating systems would be greater than one even without network effects: the high fixed and low unarginal costs of producing operating system software imply siguificant economies of scale, which might well produce one or only a few standard systems even without the additional benefits derived from network effects. Assuming that operating systems are subject to strong virtual network effects, it is hard to see what the Antitrust Division or anyone else could do to "open the market to competition" in the long run. ${ }^{80}$ Absent governmental intervention or other barriers, the market should gravitate toward the most efficient number of operating systems, which may well be one and certainly is not many. ${ }^{81}$ The government's economics expert, Nobel laureate Kenneth Arrow, made a related point in his affidavit. ${ }^{82}$

Not surprisingly, Microsoft's competitors disagreed with this analysis, arguing that the increasing returns afforded by network effects made Microsoft more dangerous to other competitors and, by extension, to consumers. Judge Sporkin agreed with the competitors, holding that the

77. Microsoft, 159 F.R.D. at 322-23.

78. See Lemley, Internet Standardization, supra note 46, at 1068 ("[I]n this case the monopolist may have some legitimate claim that its monopoly has been 'thrust upon it' and is therefore not illegal under the rule of United States v. Aluminum Co. of America (ALCOA) [148 F.2d 416, 429 (2d Cir. 1945)].").

79. See infra note 484 and accompanying text.

80. See Lemley, Internet Standardization, supra note 46, at 1069-72 (suggesting that even structural antitrust relief will be only a temporary solution to a real network effects problem); Alan Murray, Antitrust Isn't Obsolete In a Era of High-Tech, WaLl ST. I, Nov. 10, 1997, at I ("No one, of course, is proposing breaking up Microsoft or the Windows monopoly in order to promote innovation in operating systems; that war is over, and Microsoft won."). On this view, the Antitrust Division's case was destined to be "ineffective" regardless of the relief it sought. See JoNATHAN BAND \& MASANOBU KaTOH, INTERFACES ON TRIAL 45 (1995) (arguing that the ineffectiveness of the Microsoft consent decree demonstrates the shortcomings of antitrust); $c f$. Baseman et al., supra note 73, at 299 (criticizing the Antitrust Division's response as ineffective).

81. Whether that operating system would necessarily be Microsoft's is another matter.

82. See Microsoft, 159 F.R.D. at 333-34. 
presence of network effects should in essence be an aggravating factor in a monopolization claim..$^{83}$ Judge Sporkin discounted Arrow's affidavit on the ground that

[i]f it is concededly difficult to open up an increasing returns market to competition once a company has obtained a monopoly position, the Government has not shown how prospectively prohibiting violative conduct that contributed to defendant's achieving its monopoly position will serve to return the market to where it should have been absent [Microsoft's] anticompetitive practices. ${ }^{84}$

While the Division's argument concerned effective remedies, ${ }^{85}$ Judge Sporkin's arguinent focused ex post on Microsoft's conduct, contending that network effects made it easier for the company to keep a monopoly once acquired. The court's reference to where the market "should have been" is particularly telling; the court appears concerned that Microsoft does not face effective competition. Judge Sporkin traces the causes of Microsoft's market power to a combination of network effects and anticompetitive conduct. His evident desire is to undo the effects of both-"returning" the market to an idealized state of competition in which multiple companies contend vigorously but fairly against one another and the price of goods is set at or near marginal cost. If this was the goal, Judge Sporkin was doomed to failure, even before he was cut short by the D.C. Circuit. Courts cannot normally "undo" network effects with the tools of antitrust. ${ }^{86}$ Network effects are an inherent part of certain markets, not a "market failure" for which the law must necessarily correct. The law may need to adapt to network effects, but it should neither iguore them nor attempt to defy them.

One might characterize Judge Sporkin's concern in a more limited sense-as a worry about artificial barriers to entry. ${ }^{87}$ Antitrust law is properly concerned in non-network markets with high barriers to entry, since such barriers undermine the ability of potential competitors to discipline existing firms in a market in the short run. ${ }^{88}$ Strong network

83. Cf. Joel Klein \& Preeta Bansal, Intemational Antitrust Enforcement in the Computer Industry, 41 VIL. L. REv. 173, 178 (1996) (suggesting that network effects in the computer industry require that the Antitrust Division be "especially vigilant" in preventing a de facto standard setter from manipulating a standards competition).

84. Microsoft, 159 F.R.D. at 334 (second emphasis added).

85. Cf. Levinson, supra note 73 , at 180 (noting that the govcrnment did not attempt to "remedy" the network effects problem).

86. See Lemley, Internet Standardization, supra note 46, at 1069-72 (discussing the futility of antitrust efforts to rid the operating systems market of network effects).

87. Joel Klein, head of the Antitrust Division, made this point in a recent article. See Klein \& Bansal, supra note 83 , at 178 .

88. See, e.g., Roger D. Blair \& David L. Kaserman, Antitrust Economics 32-35 (1985). 
effects are themselves a barrier to entry ${ }^{89}$ though it is not at all clear that entry into such a market ought to be encouraged. The - Antitrust Division's theory in Microsoft appears to be somewhat different-that in a market with weak network effects, but in which competition is still desirable, a firm might employ anticompetitive practices to further raise the barriers to entry, foreclosing useful competition that otherwise might have occurred. This is a plausible theory in certain types of "partial network effects" markets; whether the operating systems market belongs in that category is another matter.

The implicit debate in United States v. Microsoft over the significance of network effects is replicated in the academic commentary on the "vaporware" issue. ${ }^{90}$ The competitive effect of vaporwareallegedly predatory preannouncements of nonexistent productsdepends heavily on network effects. As Stephan Levy has observed, lying to customers about a product ship date erodes goodwill; a company can deceive most customers only a few times before they begin to question all the company's product announcements. ${ }^{91}$ For vaporware to be worthwhile, the producer must therefore capture more from an early lie than it loses later in diminished credibility. Network effects may offer a credible explanation for such a strategy-the consumer who is deceived into waiting for a product in a standards competition may find herself with a substantial disincentive to switch products if the vaporware product does indeed become a market standard when it is finally introduced. By preannouncing a product, a large company may therefore influence the outcome of a standards competition in an industry characterized by network effects. ${ }^{92}$

Absent network effects, though, it is difficult to see why anyone would be concerned about vaporware as an antitrust issue. Repeated efforts to deceive customers might be punishable as fraud or deceptive advertising $^{93}$ if the market does not discipline the company, but it is

89. See David S. Evans \& Bernard Reddy, Some Economic Aspects of Network Industries and Their Relevance to Antitrust in the Computer Industry in CUTTING EDGE Issues IN NETwORK INDUSTRIES 1, 22-23 (1996).

90. On the vaproware issue generally, see Joseph Farrell \& Garth Saloner, Installed Base and Compatibility, 76 AM. EcoN. REv. 940 (1986). In addition to claims against Microsoft, "vaporware"-style allegations were periodically made against IBM during its period of market dominance. See Lawrence A. Sullivan, Monopolization: Corporate Strategy, the IBM Cases, and the Transformation of the Law, 60 Tex. L. REv. 587 (1982).

91. See Stephan M. Levy, Should "Vaporware" be an Antitrust Concern?, 42 ANTrTRust BuLL. 33, 34 (1997).

92. See Besen \& Farrell, supra note 49, at 123-24; Prentice, supra note 74, at 1226-31; see also Lemley, Internet Standardization, supra note 46, at 1074 ("Because de facto "standard-setting is a high-stakes game-the winner gets a durable monopoly for several years, and the losers get nothing - participants in this competition may be expected to try to tip the balance in their favor.").

93. False advertising may be enjoined in an action by the Federal Trade Commission pursuant to the Federal Trade Commission Act, 15 U.S.C. $\$ \S 45,52$ (1994), pursuant to state acts modeled on the 
unlikely that deception could really lead to market power in a nonnetwork market. For this reason, the debate over the anticompetitive harm of vaporware in Microsoft seems to devolve into an empirical debate over whether network effects actually exist in that market. ${ }^{94}$ (Of course, even if vaporware turns out to be potentially anticompetitive in the operating system software market, it does not necessarily follow that antitrust law will be particularly good at distinguishing vaporware from honest mistakes. ${ }^{95}$ )

A second allegation leveled at Microsoft also hinges on network effects. In a letter to the Antitrust Division in 1996, Netscape's outside counsel, Gary Reback, asserted that Microsoft was payimg computer manufacturers and Internet service providers to feature Microsoft's Internet Explorer Web browser (which is already given away for free) and to make it more difficult to use Netscape's Navigator browser, its largest competitor. ${ }^{96}$ Once again, at base the argument is that Microsoft is trying to "tip" a network market in its favor during a standards competition, presumably in the hope that it will capture a lucrative market with "locked-im" customers (or at least that it will preserve its existing power in the computer operating systems market). ${ }^{97}$

Uniform Deceptive Trade Practices Act, or in a private action by competitors under section 43(a) of the Lanham Act. See, e.g., Johnson \& Johnson Merck Consumer Pharmaceuticals Co. v. Smithkline Beecham Corp., 960 F.2d 294 (2d Cir. 1992). See generally Lillian R. BeVier, Competitor Suits for False Advertising Under Section 43(a) of the Lanham Act: A Puzzle in the Law of Deception, $78 \mathrm{VA}_{\mathrm{A}}$ L. REv. 1 (1992).

94. Compare Baseman et al., supra note 73, at 295-98 (network effects prevalent in Microsoft case), with John E. Lopatka \& William H. Page, Microsoft, Monopolization, and Network Externalities: Some Uses and Abuses of Economic Theory in Antitrust Decision Making, 40 ANTITRUST BuLl. 317, 335-55 (1995) (doubting both the general theory of network effects and its particular application to the Microsoft case). For empirical evidence on the network character of software markets, see Neil Gandal, Competing Compatibility Standards and Network Externalities in the PC Software Market, 77 Rev. Econ. \& STAT. 599 (1995), and Shane M. Greenstein, Did Installed Base Give an Incumbent Any (Measurable) Advantages in Federal Computer Procurement?, 24 RAND J. ECON. 19 (1993), both of which suggest that the software market exhibits network effects.

95. On this point, see Levy, supra note 91, at 42-43; Evans \& Reddy, supra note 89, at 20-21. Cf. Prentice, supra note 74 , at $1243-60$ (offering a standard that attempts to distinguish innocent misrepresentations from vaporware).

96. The text of the letter is reprinted in Gary L. Reback, Microsoft's Illegal Conduct: Text of Netscape's Letter to the U.S. Justice Department, 27:2 ANTITRuST L. \& EcoN. REv. 97 (1996).

97. A related-and potentially more troubling-accusation is that Microsoft is attempting to "propertize" the TCP/IP protocol stack by bundling its particular version into Windows 95. See Willow Sheremata, Barriers to Innovation: A Monopoly, Network Externalities, and the Speed of Innovation, 42 ANTITRUST BULL. 937 (1997). One commentator worries that "the TCP/P standard will become whatever Microsoft wants it to be. This 'public' standard will, in fact, become a proprietary protocol manipulated by a single vendor...." John Davidson, Microsoft Endangers TCP/P Standard, COMPUTERWORLD, Jan. 15, 1996, at 37. For a contrary view from one of Microsoft's rivals, Sun's Scott McNealy, see McNealy Defends Java Purity-Microsoft will cave in on Java, he says (visited Nov. 22, 1997) <http://www.newspage.com/network/export/ st..ory $=c 1117357.3 \mathrm{mp} \&$ topic $=2984 \&$ date $=1997112>$. 
But it would not necessarily be a bad thing for consumers if Microsoft won a standards competition. ${ }^{98}$ If consumers would have otherwise divided into two groups purchasing incompatible software, "predatory" conduct that induces them all to buy Microsoft's product will in fact enhance social welfare, since all consumers will benefit from the positive network effects of using a single product. Mark Patterson notes that a standard-enhancing move in a network market might enhance efficiency on balance, even if it eliminates competition, since consumers of the standard product will benefit from increased adoption of the standard. ${ }^{99}$ In effect, a new dimension of network effects must be considered for antitrust purposes-whether allegedly anticompetitive conduct serves to help tip what would otherwise be a balanced, multiproduct industry toward a monolithic standard. Far from being a bad thing, as antitrust law traditionally would conceive it, such a marketshare-enhancing move could be treated as procompetitive-at least to the extent that the social welfare benefits would have to be balanced against any anticompetitive effects. For example, if Microsoft's product were inferior to a competitor's, the cost of standardizing a suboptimal product should be considered in deciding the net effect on social welfare. ${ }^{100}$

A related issue concerns Microsoft's increasing tendency to bundle various application programs, such as word processing software or its own Web browser, with its operating system. ${ }^{101}$ In a standard antitrust context, this problem is called "tying." Antitrust law generally permits the combined sale of two products that a manufacturer could produce separately so long as the combined sale realizes some (albeit ill-defined) level of efficiency. ${ }^{102}$ If the operating system is itself subject to strong network effects, then the process of expanding the boundaries of that system to include what previously would have been considered a separate product presents a potentially potent case of anticompetitive tying. Again, however, if network effects are sufficiently strong at the application program level, then the efficient number of Web browsers may not

98. See Daniel J. Gifford, Microsoft Corporation, the Justice Department, and Antitrust Theory, 25 Sw. U. L. REv. 621, 638 (1996) ("Maybe [Microsoft'sl present large market position is socially beneficial rather than the opposite.").

99. See Mark.R. Patterson, Coercion, Deception, and Other Demand-Increasing Practices in Antitrust Law, 66 ANTITRUsT L.J. 1, 74-75 n.323 (1997).

100. But if consumers can tell Microsoft's product is inferior, they might be expected to reject it in favor of a better product, coalescing around that alternate standard. It is only where we should expoct the standards competitions to be biased in some way that we should worry about selecting a suboptimal standard. See Lemley, Internet Standardization, supra note 46, at 1073-78.

101. See Reback, supra note 96 , at 97 (making allegations regarding Microsoft's bundling of its Web browser with its operating system).

102. See HovenKaMP, supra note 52 , at $\S 10.5$, at $366-69$. 
be very much greater than the efficient number of operating systems, and tying might appear less worrisome..$^{103}$

The Justice Department brought a claim against Microsoft in 1997 for bundling the browser into a forthcoming operating system, styling it as a violation of the 1994 consent decree and seeking to punish Microsoft for contempt. That action was still pending at this writing. In December 1997, Judge Jackson concluded that Microsoft had not acted in contempt of the consent decree, but nonetheless issued a preliminary injunction precluding Microsoft from conditioning the sale of any operating system on the license and installation of its Web browser. ${ }^{104}$

Even if the government is successful im preventing the linkage between Windows 95 and Internet Explorer, it may not change the structure of the market. The operating system market will still be characterized by strong network effects under Microsoft's control. The success or failure of Netscape's competition in the browser market seems unlikely to affect that result, unless Netscape can find a way to turu its browser into a "meta" operating system. It is possible that Sun's Java technology will radically restructure the industry, opening it to effective interoperability between operating systems in just this way. ${ }^{105}$

\section{ATM Networks}

Claims of network effect have also played a significant role in recent years im automated teller machine (ATM) network markets. ATM networks exhibit what Charles Rule has called "economies of ubiquity." 106 In other words, consumers benefit from broad acceptance of their ATM cards. Thus, agreements expanding the network of banks that will honor a particular ATM card benefit both consumers at the newly-added bank (because they can now get cash at a host of other institutions) and consumers at all other participating banks (because they now have an additional source of cash). Indeed, consumer

103. Interoperability between products may solve such problems to some degree, as we discuss below. See infra notes $499-501$ and accompanying text.

104. See United States v. Microsoft, 980 F. Supp. 537 (D.D.C. 1997). The court concluded that the government was likely to succeed on the merits of the tying claim, noting that "the government has shown that there exists sufficient, independent consumer dentand for operating systems and Internet access software 'so that it is efficient for a firm to provide' those products 'separately,' as Microsoft has concededly done." Id.

105. We explore the possibility in more detail in a forthcoming paper. See Mark A. Lemley \& David McGowan, Could Java Change Everything? The Competitive Propriety of a Proprietary Standard, 43 ANTITRUsT BuLl. (forthcoming 1998).

106. Charles F. Rule, Antitrust Analysis of Joint Ventures in the Banking Industry Evaluating Shared ATMs, in CUTTING EDge Issues IN NETwORK INDUSTRIES 1, 6 (1996). 
convenience would be enhanced to the greatest degree if every bank were on the same ATM network. ${ }^{107}$

At the same time, ATMs do not constitute an actual network effects market. First, participation in an ATM network is not necessary to the very existence of the product. Unlike a telephone, an ATM card remains useful even if it only allows someone to get cash at her home bank. A certain level of demand will be necessary for the bank to adopt ATM technology, but additional customers do not add value to the cards of earlier customers in the same way that additional members of communications networks do. While an intermittent demand-side benefit may exist, in which a bank might add further ATM machines only as it reaches various plateaus of new customers, this effect is relatively diffuse when compared to the dynamics of actual networks. Further, expansion of ATM networks is subject to diminishing returns because members of large ATM networks will likely already be close to a machine that accepts their card; if that is true, the incremental convenience from a new bank joining the network is likely to be low. At some point, therefore, consumers in Texas may prefer competition between networks to the marginal value of adding a fourth bank in, say, Guatemala to their network. ${ }^{108}$ (By contrast, the marginal value to an unaffiliated bank of joining such a network may increase with the size of the network joined. ${ }^{109}$ )

One recent case has brought this issue into sharp relief. In Money Station v. Board of Governors of the Federal Reserve System, ${ }^{110}$ the owner of a small ATM network challenged a merger between two other ATM networks, including the largest such network in the United States ("MAC"). The plaintiff argued that

[i]f the current applications are approved, the already high barriers to entry for effective competition will be at prohibitive levels because no other network... will be able to attain the critical mass of ATMs necessary to support a network that could

107. Accord The Treasurer, Inc. v. Philadelphia Nat'1 Bank, 682 F. Supp. 269, 271-72 (D.N.J. 1988), aff'd mem. 853 F.2d 921 (3d Cir. I988) ("[T]he principal competitive advantage of any ATM network is the number of ATMs utihized by the system. Financial institutions prefer a large system because it increases the potential for interbank transactions and therefore, more profit from interchange fees. Consumers generally prefer a system with a large number of ATMs because of the greater convenience offered by such a system. In addition, because ATM systems entail substantial capital and operating costs, a high volume of transactions is necessary to make the machine cost effective.").

108. See Donald I. Baker, Shared ATM Networks-The Antitrust Dimension, 41 ANTITrust BULL. 399, 411 (1996) (noting the tradeoff between increased consumer access to cash and competitive pricing for ATM services).

109. See BancOne Corp., 81 Fed. Res. Bull. 492, 494 n.20 (1995) ("[B]anks tend to place a greater value on membership in a network as its membership expands.").

110. 81 F.3d 1128 (D.C. Cir. 1996), reh'g granted, 94 F.3d 658 (D.C. Cir. 1996); appeal dismissed, 1997 U.S. App. LEXIS 3121 (D.C. Cir. 1997). 
[compete with MAC] .... Once MAC locks up virtually all the ATMs in the Pennsylvania-Ohio-Kentucky area as customers of its branded network through the transaction with Mellon and NCC, there will be an insufficient number of banks to create a "critical mass" necessary for a new network to be formed .... 111

The plaintiff's argument was based on the premise that competition between ATM networks was important to consumer welfare. The Federal Reserve Board rejected this idea, relying primarily on network theory. The Board's decision concluded that "[n]etwork externalities, such as the economies of ubiquity, tend to promote the consolidation of regional ATM networks. ... [T] [he Board believes that, as a result of economic and market structure conditions, regions are likely to have one dominant ATM network." 112

The D.C. Circuit reversed the Board's decision on procedural grounds. The court appeared to agree that the market was subject to network effects but held that those effects would not excuse a merger that would reduce potential competition in the market for ATM networks. According to the D.C. Circuit, the Board's response to such effects should be to encourage larger competitors rather than a single dominant network. ${ }^{113}$ One need not draw this conclusion, however. Particularly if one believes network effects in ATM markets are strong, the Circuit Court's (now vacated) position is inconsistent with the reasoning supporting the Microsoft consent decree (though the issues before the court in that case related more to jurisdiction and statutory construction than market economics) and could well lead to decreased efficiency. At least one commentator has argued that the existence of network effects in the ATM market means that the government ought to actively seek to abolish competition between networks, on the grounds that it is costly and will ultimately serve no purpose. ${ }^{114}$

Ironically, legal use of the network effects idea in the ATM market originally centered on the antitrust problems raised by entering into network arrangements at all. Antitrust law has historically been hostile to agreements between competitors; ${ }^{115}$ ATM networking certainly has this

111. Id. at 1131 .

112. Id. at 1133 (quoting Board decision).

113. See id. at 1133-34 \& n.7. Judge Edwards dissented and would have affirmed the Board's conclusion. Judge Silberman, author of the Circuit opinion in Microsoft, filed the following statement upon entry of the stipulated order dismissing the case: "I am utterly befuddled as to why, under the circumstances, the Federal Reserve Board agreed to dismiss the case." 1997 U.S. App. LEXIS 3121, at $* 2$.

114. See Joshua B. Konvisser, Coins, Notes and Bits: The Case for Legal Tender on the Internet, 10 HaRv. J.L. \& TECH. 321, 335-37 (1997).

115. See 15 U.S.C. § 1; Eastern States Retail Lumber Dealers, Ass'n v. United States, 234 U.S. 600, 614 (1914); Lemley, Internet Standardization, supra note 46, at 1079-80. 
characteristic. The existence of network effects in a market is a persuasive reason not to outlaw all such agreements between competitors without detailed inquiry into their actual economic effects. Commentators have argued for more lenient antitrust treatment of informationsharing where network effects are present, particularly in the ATM industry. ${ }^{316}$ This form of network effects argument is in some sense the opposite of Judge Sporkin's in the Microsoft context and of the D.C. Circuit's dicta im Money Station: here the argument is that network effects ought to exculpate rather than inculpate.

More recently, argument about the role of network effects in the ATM mdustry has focused not on the legality of ATM networks vel non, but on the standards for access to such networks. ${ }^{17}$ Challenges to the rules of ATM networks may take one of several forms. First, a bank or other financial institution ${ }^{118}$ that is not permitted to join an ATM network may claim it has been denied access to an "essential facility," or that its competitors unfairly refused to deal with it. ${ }^{119}$ While essential facility claims in antitrust are rarely successful, ${ }^{120}$ numerous states have stepped into this market with legislation mandating nondiscriminatory access to ATMs. ${ }^{121}$ Interestingly, one commentator has objected to antitrust claims demanding nondiscriminatory access, arguing that they reduce competition by creating a "de facto merger" of the networks that interoperate. ${ }^{122}$ While this is true in some sense, if the market is truly characterized by network effects, such interoperability between standards may not be a bad thing. ${ }^{123}$ At the least, the benefits of standardization must be weighed against the risk that the standard chosen will be suboptimal.

116. See, e.g., Carlton \& Klamer, supra note 5, at 447; Thomas A. Piraino, Jr., The Antitrust Analysis of Network Joint Ventures, 47 Hastings L.J. 5,9 (1995); Rule, supra note 106, at 1.

117. See generally United States v. Elec. Payment Servs. Consent Decree, 59 Fed. REg. 44,757 (1994) (discussing the settlement of the Antitrust Division's action against the MAC ATM network). For a discussion of another Antitrust Division investigation, see Margaret E. Guerin-Calvert, Current Merger Policy: Banking and ATM Network Mergers, 41 ANTITRUST BuLl. 289, 319-21 (1996).

118. See Complaint of the Competition Tribunal at 135 , Competition Tribunal v. Bank of Montreal, CT-95102 (Dec. 14, 1995) (alleging that ATM networks conspired to exclude financial institutions other than banks from participating in the network).

119. Such claims are fairly common in a variety of markets in which groups of competitors form joint ventures. See, e.g., Northwest Wholesale Stationers v. Pacific Stationery \& Printing, 472 U.S. 284 (1985). For more on such claims in network industries, see Lemley, Internet Standardization, supra note 46, at 1083-86; McGowan, supra note 11, at 836-49.

120. See Phillip Areeda, Essential Facilities: An Epithet in Need of Limiting Principles, 58 ANTITRUST L.J. 841, 841 (1990); McGowan, supra note 11, at 804.

121. See Donald I. Baker \& Ronald E Brandel, The Law of Electronic Funds Transfer Systems $\S 21.01, \S 25.02[4][a]$ (1995) (surveying such laws).

122. See Baker, supra note 108 , at $412-13$.

123. Cf. McGowan, supra note 11 , at $833-35$ (noting that interoperability is the preferred solution to network effects problems in the software industry). 
Second, banks may challenge exclusivity rules in ATM networks. Most banks now participate in more than one ATM network, a fact that may significantly ameliorate the potential anticompetitive effects of network consolidation. ${ }^{124}$ And in a recent case, an antitrust plaintiff alleged that MAC's policy precluding members from participating in a competing ATM network effectively reduced competition in the ATM network market. ${ }^{125}$

Finally, members of an ATM network (or consumers) might object to fee arrangements or purchase requirements they find onerous. ${ }^{126}$ For example, a mandatory network interchange fee significantly reduces transaction costs because it prevents each member of the network from having to negotiate fees for interchange with each other member. On the other hand, key players im the network can easily use such a provision to set interchange fees at a noncompetitive level. ${ }^{127}$ There has been antitrust litigation on the related issue of ATM network rules restricting the fees that banks may charge ATM users. In one recent case, a district court rejected an antitrust challenge to a "no surcharge" rule imposed by the PLUS System, concluding that such a rule was not illegal price fixing. ${ }^{128}$

In each of these latter cases, the argument is not so much about the existence of network effects im the ATM network market as it is about the ways in which the legal evaluation of permissible conduct is informed by the existence of those effects. For example, in a non-network market, neither exclusivity nor denial of access raises significant antitrust conceru in the absence of both market power and siguificant barri-

124. However, such multiple networking presents a different antitrust problem, relating to how transactions will be routed over multiple possible networks. If a transaction could be carried over either one of two networks, consumers and card-issuing banks would presumably benefit from a rule that routed it over the least expensive network (at least, the network with the smallest interchange fee). For this reason, a mandatory routing rule in an ATM network agreement might be thought anticompetitive, since it would preclude such competition and therefore reduce the competitive benefit of having overlapping networks in the first place. See Baker, supra note 108, at 418-19.

125. See Marian Bank v. Elec. Payment Servs., No. 95-614-SLR, 1997 WL 367332, (D. Del. Feb. 5, 1997). Visa's PLUS network had a similar policy with respect to Master Card's CIRRUS network, though exclusivity between these entities ended some time ago. In particular, Rule points out that an exclusivity rule imposed by the dominant ATM network would discourage the development of supplemental networks which could conceivably compete with the dominant one, and which would therefore serve to discipline the market leader. Rule, supra note 106, at 19 . On these issues genreally, see David A. Balto, The Murky World of Network Mergers: Searching for the Opportunities for Network Competition, 42 ANTITRUST BuLL. 793 (1997).

126. For example, in Marian Bank, 1997 WL 367332, the plaintiff alleged that in order to join an ATM access network, it was compelled to purchase ATM processing services from the network's chosen vendor. See Rule, supra note 106, at 19. See generally Karen L. Grimm \& David A. Balto, Consumer Pricing for ATM Services: Antitrust Constraints and Legislative Alternatives, 9 GA. ST. U. L. Rev. 839 (1993).

127. See Rule, supra note 106 , at 17-18 (weighing pro- and anti-competitive effects of such mandatory fee structures).

128. See Southtrust Corp. v. PLUS System, 913 F. Supp. 1517, 1519 (N.D. Ala. 1995). 
ers to entry. ${ }^{129}$ Network effects may heighten antitrust scrutiny over a participant's conduct in this market-just as they did with respect to some practices in the operating systems market-because of concerns over increased barriers to entry. ${ }^{130}$ On the other hand, economies of scale might suggest the existence of procompetitive efficiencies, at least in merger cases. ${ }^{131}$ Thus, courts and regulators must be careful to distinguish between network effects and economies of scale, since the two may have very different implications for merger analysis. ${ }^{132}$

\section{Credit Card Networks}

The economics of credit card networks resemble those of ATMs in many respects. ${ }^{133}$ Once a network overcomes the chicken-and-egg problem of forming an enterprise dependent in part on existing members, consumers benefit from broad acceptance of their credit card in much the same way that they do from broad acceptance of their ATM card. Merchants are more likely to accept a card if everyone wants to use it, suggesting that additional consumer adoptions of a particular card redound to the benefit of all card holders. In addition, some (but not all) credit cards are composed of networks of card-issuing banks, which also benefit from expansions in the scope of the network since they make the card more attractive to consumers.

Nonetheless, there are subtle differences between credit card "networks"134 and ATM networks. First, unlike ATM networks, the value to consumers of adding marginal merchants does not decline. In

129. See BlAIR \& KASERMAN, supra note 88, at 32 .

130. See Baker, supra note 108, at 408 (arguing that "[n]ew entry into the "branded ATM network' market has been virtually nonexistent anywhere in the country. It requires a critical mass of cards and ATMs.").

131. See HovenKaMP, supra note $52, \S 12.2 \mathrm{~b} \& \mathrm{c}$, at $452-55$. It should be noted that the "efficiencies defense" in merger cases has met with only mixed success, largcly because the legislative history to the 1950 Celler-Kefauver Amendments to section 7 of the Clayton Act seems unambiguously to reject such a defense. See Derek Bok, Section 7 of the Clayton Act and the Merging of Law and Economics, 74 Harv. L. Rev. 226, 234 (1960); cf. Federal Trade Commission, Revision to the Horizontal Merger Guidelines § 4 (1997) (FTC will consider efficiencies attributable to merger and not resulting from restrictions of output in determining whether to challenge horizontal merger).

132. See Guerin-Calvert, supra note 117, at 320-21 (noting Federal Reserve Board approval of an ATM network merger, in part because of the economies of scale resulting from the merger).

133. For a discussion of how credit card transactions work, see Carlton \& Frankel, supra note 39, at $645-49$.

134. Credit cards are themselves networks of credit provision, while ATM cards are generally thought of as existing independently of ATM networks. To some extent, however, this is merely historical accident. Consider department store or gasoline company credit cards, for example. Just as an ATM card originally provided access to cash only at the issuing bank, so these credit cards provided aceess to credit only at the sponsoring store or chain of stores. A cross-merchant credit card Iike American Express is an innovation analogous to the development of ATM networks. For more on this history, see SCFC ILC, Inc. v. Visa U.S.A., Inc., 819 F. Supp. 956, 963 \& n.2 (D. Utah 1993), aff d in part and rev'd in part, 36 F.3d 958 (10th Cir. 1994). 
large part, this is because an ATM card is generally used for obtaining cash, while a credit card is an adjunct to a financial transaction with a third party ${ }^{135}$ Consumers need only one convenient ATM in each location, but they would prefer that every merchant with whom they do business accept their credit cards. Second, while some ATM networks are exclusive, credit card networks are nonexclusive. Consumers can and do hold more than one type of credit card, and merchants can and do accept more than one type of card. ${ }^{136}$ This nonexclusivity means that network effects will not necessarily drive the industry toward standardization, but rather toward overlapping credit card networks that may still compete in certain ways.

One aspect of this nonexclusivity was at issue in SCFC ILC v. Visa USA. ${ }^{137}$ In that case, Sears, the owner of the Discover credit card, sought to issue Visa cards as well. ${ }^{138}$ Visa denied Sears' application, enacting a Visa network bylaw that prevented member institutions from issumg competing credit cards and singling out Discover cards by name..$^{139}$ Sears challenged the bylaw on antitrust grounds. The court treated the case as involving a "joint venture" (the Visa network), and rejected per $s e$ analysis as inappropriate for such a venture. ${ }^{140}$ Rather remarkably, the court concluded that the relevant market was not the market for credit card networks, but rather the market for card issuers (of which there were 6,000 in the Visa network alone). Simce Visa did not participate in that market, the court concluded that it could not have market power. ${ }^{141}$ In so doing, the court sidestepped the fundamental nature of Sears' claim-that the Visa network was an essential facility to which it should

135. ATM cards are increasingly used as payment options in point of sale transactions, for example at gas stations and grocery stores. To the extent this holds true, the ATM point of sale network resembles the credit card network more closely than it does the ATM cash access network.

136. Consumers could hold more than one ATM card, if they used more than one bank for everyday cash needs, but most don't.

137. 36 F.3d 958 (10th Cir. 1994), cert. denied, 515 U.S. 1152 (1995).

138. Sears, which originally owned the Discover card before selling the business to Dean Witter, applied for Visa membership and was tumed down. Undaunted, Sears purchased the assets (including membership in the Visa joint venture) of a failed Utah thrift from the Resolution Trust Corporation and attempted to launch a new Visa card through that entity. See SCFC ILC, 819 F. Supp. at 964.

139. Visa members were permitted to issue MasterCards, Visa's largest credit card network competitor. See 36 F.3d at 961.

140. See id. at 963-65. See also David A. Balto, Access Demands to Payment Systems Joint Ventures, 18 HARv. JL. \& PUB. PoL'y 623, 648-56 (1995) (arguing that per se analysis is inappropriate; access to a credit card network should not be compelled unless the network is an essential facility). The per se rule allows courts to condemn some agreements under the antitrust laws without detailed inquiry into their market effect.

141. See id. at $965-69$. The court's opinion is hardly a model of clarity on this point. Further, as Carton and Frankel observe, it simply misunderstands the nature of the market power inquiry to fail to distinguish between decisions made individually by 6,000 banks and decisions made collectively by the Visa organization. See Carlton \& Frankel, supra note 39, at 653-54; see also Dennis W. Carlton \& Steven C. Salop, You Keep on Knocking but You Can't Come In: Evaluating Restrictions on Access to Input Joint Ventures, 9 HaRv. J.L. \& TECH. 319, 337-40 (1996). 
be allowed access on the same terms as any other card issuer because the facility had strong network effects. ${ }^{142}$ The court did so in part because it did not think the credit card network was so "extraordinary" as to warrant application of the essential facilities rule. ${ }^{143}$ In addition, though, the court appeared to accept Visa's argument that denying membership to Sears would promote healthy "intersystem" competition by maintaining several different networks that could compete with each other. ${ }^{144}$ The latter argument is implausible if the industry really is characterized by network effects of any strength. ${ }^{145}$ Because the effects are positive, enhancing value to users, the last thing we should do in a strong network market is divide the standard into incompatible parts. There would seem to be no greater warrant for antitrust to promote exclusive, competitive networks in such an industry than to attempt to break up Microsoft, unless the network effects were sufficiently weaker in the credit card industry to make intersystem competition a socially optimal alternative.

As the Discover card litigation deinonstrates, suits over access to the credit card network system raise many of the same sorts of group boycott and essential facilities claims discussed earlier. ${ }^{146}$ There are also some of the same fee-setting issues we saw in the ATM network context. Once again, the role network effects should play in antitrnst inquiry is unclear. ${ }^{147}$ One is left with a conundruin: an entity that allows over 6,000 members to compete with one another on price (interest rates) and on other terms does not at first glance appear anticompetitive. At the same time, it is difficult to see what harm to consumers would come from allowing competing issuers such as Discover iuto the system; a 6,000member joint venture is likely not deriving a siguificant portion of its value from exclusion of competitors. On the other hand, with 6,000 banks competing within the system, allowing new members such as Sears to join might not confer inuch in the way of marginal benefits to consumers.

We are left with an intuition, though admittedly little in the way of evidence or analytical proof, ${ }^{148}$ that, if relatively strong network effects can be shown to exist, open standards are likely to do less harm in this area than mandating competing closed systeins. Remedies for achieving

142. See 36 F.3d at 971 .

143. See id.

144. See id. at 969.

145. Perhaps we are too cynical, but we also find it difficult to believe that Visa's motivation in excluding Sears from membership in its network was the pure-hearted one of wanting to encourage Sears to be a more effective competitor of the Visa network. See id.

146. See supra notes 110-132 and accompanying text.

147. See, e.g., Carlton \& Frankel, supra note 39, at $661 \mathrm{n} .42$ (network effects may mean that credit card interchange fee system has procompetitive consequences).

148. It is worth noting, however, that when AT\&T entered the market with a no-annual-fee credit card, most other card issuers quickly followed suit. See id. at 653. 
that end are, admittedly, problematic. For now, we note that among other things one must take into account the value that members of the existing network derive from the network's brand-the Visa or MasterCard trademarks - and whether allowing other branded cards to join the network would diminish that value. ${ }^{149}$ There is little question that these marks have value, as do competitive marks such as American Express and Discover. If Discover were allowed to jom the Visa network, it might well receive benefits created by Visa's investments in brand loyalty. But that issue could perhaps be treated better in negotiations over an access price rather than by maintaining fragmentary standards in a strong network market.

\section{Standard-Setting Organizations ${ }^{150}$}

The problems with "winning" and "losing" standards in network effects industries generally arise when standards are incompatible, forcing consumers and developers to choose between them. Competitions between incompatible standards have a "winner-take-all" quality, rewarding the developer of a new standard by giving him the full value of the standard itself and not just the value of his contribution. ${ }^{151}$ This result is inefficient. Network theory, which posits mcremental benefits to existing users from network growth, suggests that network goods optimally should be priced as low as possible to allow widespread adoption of the standard. ${ }^{152}$ A proprietary standard owned by a single, "winning" company that can set whatever price it wants is not the best way to achieve this goal because monopolists maximize their revenue by

149. The authors wish to disclose that one of us (McGowan) has represented American Express in trademark litigation adverse to Visa.

150. This section builds on the discussion in Lemley, Internet Standardization, supra note 46, at 1059-65.

151. See David Friedman, Standards as Intellectual Property: An Economic Approach, 19 U. DAYTON L. REv. 1109, 1121 (1994). Of course, in practice most standards competitions are not won absolutely, and minority products (like the Apple operating system) do continue to exist. Nonetheless, it is clear that the benefits to becoming the dominant standard-setter are substantial. But $c f$. Daniel J. Gifford, supra note 98 , at 642 (suggesting that this fringe competition makes the network externalities argument less important). The prospect of large returns also gives firms an incentive to spend resources competing for the prize. See Besen \& Farrell, supra note 49, at 120 ("The more skewed are the returns, the harder firms will fight; and the sharper the available tactics, the more fighting will dissipate profits. Prizes are typically more skewed under inter-technology competition, because the likelihood of tipping gives it an all-or-nothing flavor.").

152. See Joseph Farrell, Arguments for Weaker Intellectual Property Protection in Network Industries, in StaNdards POLICY FOR 1NFORMATION 1NFrastructure 369 (Brian Kahin \& Janet Abbate eds., 1995) ("[W]hen network effects are present, each user deterred by a price above cost not only loses the benefit of the innovation for himself but also reduces the benefit to all those who do adopt. So a given reduction in demand is more harmful when network effects are important."). 
raising prices above the competitive level and therefore excluding some participants (at least absent perfect price discrimination). ${ }^{153}$

One possible solution to the standardization problem is to make the competing standards mteroperable. If people can switch back and forth between competing versions of what is essentially the same standard, perhaps society can capture the benefits of competition without wasteful duplication of effort and without stranding consumers who make the wrong choice. ${ }^{154}$ Elsewhere, we have suggested ways in which interoperability might be achieved in the Internet context. ${ }^{155}$

One approach to achieving interoperable standards is for a private industry organization open to all members to adopt a single standard. ${ }^{156}$ If the members of such a group collectively have a significant market share, their adoption of a standard may produce the "tipping" effect described above, bringing the rest of the industry into line. ${ }^{157}$ Private standard-setting organizations are more efficient than government

153. Nor does a proprietary standard seem necessary to encourage the production of future works of intellectual property. While this is the purpose behind providing intellectual property protection, the winners of standards competitions may receive a windfall that is far greater than what intellectual property normally gives as an incentive to invention.

154. Such group standard-setting is common in the computer hardware industry. Another more recent example is the market for digital video discs, where competing groups (Sony-Philips and Toshiba-Matsushita) offering incompatible standards agreed to use a single compatible format incorporating elements from both products. See Ty Ahmad Taylor, My Way or the Highway, N.Y. TIMES, Mar. 18, 1996, at D5. There is some recent empirical evidence to suggest that open, group-set standards produce cost savings over proprietary standards. See Joseph Bailey et al., The Economics of Advanced Services in an Open Communications Infrastructure: Transaction Costs, Production Costs, and Network Externalities, 4 INFo. INFRASTRUCTURE \& POL'Y 225, 271-72 (1995); E. Robert Yoches \& Kenneth M. Frankel, Legal Implications of Standards in the Computer and Software Industries, in INTEllectual Property ANTIrRust 775, 775 (1995) ("As the computer industry reaches maturity, it has learned few lessons as important as the need for 'open systems."').

155. See Lemley, Internet Standardization, supra note 46, at 1059-65.

156. Such private organizations are relatively common in a variety of industries. For a historical review of standard setting in the United States, seo D. Linda Garcia, Standard Setting in the United States: Public and Private Sector Roles, IEEE M1CRo, Dec. 1993, at 28-35. Significantly, Farrell concludes for a variety of reasons that strong intellectual property protection is likely to hamper formal private standard-setting. See Farrell, supra note 152, at 44-45; see also Mark Shurmer \& Gary Lea, Telecommunications Standardization and Intellectual Property Rights: A Fundamental Dilemma?, in STANDARDS POLICY FOR INFORMATION INFRASTRUCTURE, supra note 152, at 384-89; Yoches \& Frankel, supra note 154, at 775. For more on this approach, see infra notes 190-268 and accompanying text.

157. Of course, not all standard-setting groups have such market control. As Libicki observes, many of the most successful group standards started small and grew to becoine dommant. See Martin C. Libicki, Standards: The Rough Road to the Common Byte, in STANDARDS Policy For INFORMATION INFRASTRUCTURE, supra note 152, at 75; see also Jim Isaak, Information Infrastructure Meta-Architecture and Cross-Industry Standardization, in STANDARDS POLICY FOR INFORMATION INFRASTRUCTURE, supra note 152, at 100, 101 (argning that group or open standards "must also reach the status of being 'de facto' to be sufficient"). 
organizations in several respects. ${ }^{158}$ Because they are more marketoriented, they are less likely than their government counterparts to settle on an inefficient standard. If they do choose an inefficient standard, it may be less entrenched than an equivalent government standard, because private standards are potentially subject to "leapfrogging"-that is, being surpassed rapidly by a new standard. Significantly, private group standard-setting may also be more efficient than de facto standardization, since having multiple companies participating in a standard means that those coinpanies can compete to offer products incorporating the standard after it is selected, thus expanding output and lowering prices. ${ }^{159}$ In Katz and Shapiro's model, group standard-setting trades off first-round competition (to set the de facto standard) to achieve competition within the standard in later periods. ${ }^{160}$

To be sure, private group standard-setting has problems. Private groups are not immune from capture, particularly where the standard to be set excludes rather than includes competitors. ${ }^{161}$ Agreement on private standards can be a time-consuming process, delaying innovation based on the standard while it is being set. ${ }^{162}$ Private groups may also be a front for a cartel. ${ }^{163}$ Further, even an efficient open standard may become problematic over time. While an open standard allows an industry to evolve to improved technology as innovation progresses, that evolution may result in a group standard that becomes more cumbersome over time as successive refinements are added to it. For example, it is probable that Microsoft's Windows operating system is more cumber-

158. For a general discussion of the benefits of group standard-setting, see Douglas D. Leeds, Raising the Standard: Antitrust Scrutiny of Standard-Setting Consortia in High Technology Industries, 7 FordhaM INTEll. Prop. Media \& ENT. L.J. 641, 643-649 (1997).

159. See Henry W. Chesbrough \& David J. Teece, When is Virtual Virtuous?, Harv. Bus. Rev., Jan.-Feb. 1996, at 65, 69 (offering the IBM PC standard as an example of an open standard that resulted in significant intrastandard competition).

160. See Besen \& Farrell, supra note 49, at 121 ("Most analysts beheve that price competition is more intense when vendors' products are compatible, both because product variety is reduced and users are less likely to be locked-in to a single firm's product."); Katz \& Shapiro, Systems Competition, supra note 25, at 111; William E. Cohen, Competition and Foreclosure in the Context of Installed Base and Compatibility Effects, 64 ANTITRust L.J. 535, 550 (1996).

161. A clear example of an attempt to capture a private standard-setting organization is chronicled in Allied Tube \& Conduit Corp. v. Indian Head, Inc., 486 U.S. 492 (1988). In that case, Indian Head sought permission from the National Fire Protection Association to market polyvinyl electrical conduit. This required the NFPA to alter the National Electrical Code it had previously written, which allowed only steel conduit. Allied Tube, the nation's largest maker of steel conduit, packed the NFPA meeting and voted down the proposal. See id. at 496-97; David McGowan \& Mark A. Lemley, Antitrust Immunity: State Action and Federalism, Petitioning and the First Amendment, 17 Harv. J.L. \& PuB. PoL'y 293, 308-11 (1994) (discussing the Allied Tube case in detail).

162. On this problem, and some ways to avoid it, see JoSEPH Farrell, Choosing the Rules for Formal Standardization (Working Paper, Apr. 1993).

163. On cartels in network markets, see David A. Balto, NETWORKS AND EXCLUSIVITY: ANTTIRUST ANALYSIS TO PROMOTE NETWORK COMPETIIION 13-15 (Working Paper, 1997). 
some than it would be if Microsoft did not have to ensure that it was compatible with early versions of its older DOS operating system. Over time, group standards may bog down in accumulated problems resulting from the need for backward and horizontal compatibility. Nonetheless, if the choice is between a standard that evolves (as gronp standards generally do) and one that stagnates (as both government and private de facto standards are likely to do), most consumers would choose the dynamic standard, at least in an innovation-driven market like computer or Internet software. ${ }^{164}$

Open standards present certain antitrust problems, however. The first such problem is that standard-setting organizations may be vulnerable to challenge because they involve a horizontal agreement between competitors in violation of section 1 of the Sherman Act. ${ }^{165}$ While such horizontal agreements have historically been treated as illegal per se, there is reason to be optimistic that courts will apply the more lenient rule of reason im standard-setting cases and will recognize that the efficiencies that flow from open standard-setting in network effects industries are different and much greater than those in ordinary industries. ${ }^{166}$

The second problem arises from the important difference between open and closed standard-setting organizations. If membership in a standard-setting organization is limited to a subset of the full industry, and if the standard it produces is both one from which non-members can be excluded and which possesses durable market power due in part to network effects, refusal to allow open participation in the standard may have anticompetitive effects that antitrust law properly should address. Similar problems can occur even in nominally open groups, if voting or participation rules are structured im such a way that a subset has effective control.

Antitrust treats such claims of exclusion from private groups in one of two ways. First, closing the group might be viewed as a horizontal group boycott or concerted refusal to deal with competitors. While the

164. See Shane Greenstein, Markets, Standards, and the Information Infrastructure, IEEE Micro, Dec. 1993, at 36 (arguing that on balance the benefits of private standard-setting outweigh the costs). 83.

165. For more detail on this issue, see Lemley, Internet Standardization, supra note 46, at 1079-

166. See Consolidated Metal Prods. v. American Petroleum Inst., 846 F.2d 284, 292 (5th Cir. 1988); Dennis W. Carlton et al., Communication Among Competitors: Game Theory and Antitrust, 5 Geo. MAson L. Rev. 423, 424-25 (1997); Evans \& Reddy, supra note 89, at 11; Thomas M. Jorde \& David J. Teeee, Rule of Reason Analysis of Horizontal Arrangements: Agreements Designed to Advance Innovation and Commercialize Technology, 61 ANTrrRust L.J. 579, 600 (1993); Lemley, Internet Standardization, supra note 46, at 1079-83 (citing cases and commentators); William H. Pratt et al., Refusals to Deal in the Context of Network Joint Ventures, 52 Bus. LAw. 531, 536-37 (1997); David J. Teece, Information Sharing, Innovation and Antitrust, 62 ANTITRUST L.J. 465, 475 (1994) ("The advantages to society associated with the wide-spread adoption of common standards can be very large, as network externalities are often considerable."). 
parameters of the antitrust prohibition against group boycotts are far from clear, ${ }^{167}$ the Supreme Court's decision in Northwest Wholesale is instructive. There, the plaintiff sued a wholesale purchasing cooperative that had denied it membership (and accompanying discounts on products purchased in bulk by the cooperative). The Court nominally applied a per se rule, condemning the joint refusal to deal without detailed analysis of its competitive effect. In fact, however, the Court seems to have engaged in a market-power-based inquiry under the "rule of reason," seeking to determine the importance of membership to effective competition and whether "the boycotting firms possessed a dominant position in the relevant market."168 The rule against group boycotts has also been applied (again under the rule of reason) to the New York Stock Exchange, a body that is at least in part a standard-settmg organization. ${ }^{169}$

Alteruatively, antitrust might treat access to a standard-setting organization (or at least the interface standards set by the organization) as an "essential facility." Under this doctrine, the owners of facilities that are essential to effective competition must make them available to competitors on nondiscriminatory terms. Thus, the railroads that collectively owned the only railroad switching yard in St. Louis at the height of the railroad era were required to give all railroads access to the yard on equal terms. ${ }^{170}$ Similarly, the essential facilities doctrine has been used to compel regulated local telephone monopolies to interconnect all longdistance carriers on substantially equal terms. ${ }^{171} \mathrm{~A}$ claim that membership in a standard-setting organization (or at least access to its work product) was essential to competition in a networked industry arguably would guarantee a level playing field for all competitors, though such a result would not necessarily or automatically enhance social welfare. ${ }^{172}$

Of the two theories, we are mclined to favor the former in standardsetting cases. The essential facilities doctrine has been roundly criticized

167. See, e.g., Northwest Wholesale Stationers v. Pacific Stationery \& Printing Co., 472 U.S. 284, 294 (1985). For other statements of the confusion surrounding group, boycott law, see PHILIP areeda, Antitrust Analysis 381 (2d ed. 1974); Lawrence A. Sullivan, Handbook of the LAW OF ANTITRUST 229-230 (1977).

168. Northwest Wholesale Stationers, 472 U.S. at 294. Cf. FTC v. Indiana Federation of Dentists, 476 U.S. 447, 459 (1986) (applying a "quick look" rule of reason to an agreement by dentists to deny information to insurers). The Court in Indiana Federation held the agreement unlawful because the dentists failed to offer a procompetitive justification for their actions. See id. at 459.

I69. See Silver v. New York Stock Exchange, 373 U.S. 341, 354-55 (1963) (refusing to invalidate NYSE restrictions on membership, in part because the Exchange was already subject to heavy SEC regulation).

170. See United States v. Terminal R.R. Ass'n, 224 U.S. 383, 411 (1912).

171. See MCI v. AT\&T, 708 F.2d 1081, 1132-33 (7th Cir. 1983); Mark C. Rosenblum, The Antitrust Rationale for the MFJ's Line-of-Business Restrictions and a Policy Proposal for Removing Them, 25 Sw. U. L. REv. 605, 608-11 (1996).

172. See, e.g., Katz \& Shapiro, supra note 161. 
as overbroad. Professor Areeda called it "an epithet in need of limiting principles." 173 And the vast majority of essential facilities claims are rejected by the courts, even in circumstances in which control over a facility confers a substantial advantage upon a competitor. ${ }^{174}$ Further, a decision to apply the essential facilities doctrine to standardized industries would offer no way to distinguish group standards from individual standards, and therefore could dramatically expand the scope of antitrust intervention in the market. ${ }^{175}$ Group boycott claims, by contrast, attempt to distinguish concerted action to boycott a competitor (which is subject to scrutiny under Section 1 of the Sherman Act) ${ }^{176}$ from unilateral refusals to deal (which are generally legal). ${ }^{177}$ However, recent cases such as Northwest Wholesale suggest that the law of group boycotts is converging with the rule on essential facihties and that a group boycott will not amount to a Section 1 violation unless the plaintiff has been denied effective access to the market. ${ }^{178}$

While the issue is not free from doubt, the use of antitrust doctrine-whether it be group boycott or essential facilities-to compel access to a standard-setting organization should probably be rare. ${ }^{179}$ Not

173. Phillip Areeda, Essential Facilities: An Epithet in Need of Limiting Principles, 58 Anritrust LJ. 841 (1990); see also Christopher M. Seelen, Comment, The Essential Facilities Doctrine: What Does it Mean to be Essential?, 80 MARQ. L. Rev. 1117, 1123-25 (1997) (distinguishing between facilities essential to the public and those merely essential to competitors). But see Carlton \& Salop, supra note 141, at 320-21; FARRELL, supra note 162, at 8-9 (arguing that essential facilities claims may be justified in the circumstances of networked markets).

174. See, e.g., City of Anaheim v. Southern Cal. Edison Co., 955 F.2d 1373 (9th Cir. 1992) (access to electric power transmission lines not essential); Alaska Airlines v. United Airlines, 948 F.2d 536 (9th Cir. 1991) (access to airline computer reservation system not essential); 1llinois ex rel Burris v. Panhandle Eastern Pipe Line, 935 F.2d 1469 (7th Cir. 1991) (natural gas pipeline facilities not essential); 3 Julian O. voN KalinowsKi et al., ANTitrust Laws aNd Trade Regulation $\S 19.05[3]$, at 19-124 (2d ed. 1996) (cataloging essential facilities cases). On the other hand, the European Union may be more willing to apply the essential facilities doctrine in a broad range of circumstances. See Hartz, supra note 76, at 225-26, 230-31.

175. But cf. Maureen A. O'Rourke, Drawing the Boundary Between Copyright and Contract: Copyright Preemption of Software License Terms, 45 DuKE L.J. 479, 547 (1995) (arguing for application of essential facilities rule in the software industry whenever a software developer has market power); Jones \& Tumer, supra note 54, at 386 ("The essential facilities doctrine is easily apphied to Microsoft's possession of the leading operating system.").

176. See, e.g., Klors Inc. v. Broadway-Hale Stores, 359 U.S. 207, 210-12 (1959).

177. See, e.g., Data Gen. Corp. v. Grumman Support Servs., 36 F.3d 1147, 1182-84 (1st Cir. 1994). Some unilateral refusals to deal have been found to violate the antitrust laws under section 2. See Aspen Skiing Co. v. Aspen Highlands Skiing Corp., 472 U.S. 585, 610-11 (1985).

178. See, e.g., Pratt et al., supra note 166, at 544-45 (treating the issue as involving refusals to deal); $c f$. Robert Heidt, Industry Self-Regulation and the Useless Concept "Group Boycott," 39 VAND. L. REv. 1507, 1514-15 (1986) (stating that "group boycott" concept is unnecessary in modern antitrust law).

179. One possible approach to take in order to limit such claims is to allow government but not private suits for violations of the antitrust laws by standard-setting organizations. For a more general proposal along these lines, see Edward A. Snyder \& Thomas E. Kauper, Misuse of the Antitrust Laws: The Competitor Plaintiff, 90 Mrch. L. REv. 551 (1991). 
every organization that attempts to set industry standards must be open to all members. ${ }^{180}$ Further, vigorous application of the antitrust laws to require access to standards groups may discourage group standardsetting altogether, since companies may be unwilling for a variety of reasons to discuss their product plans with certain competitors. ${ }^{181}$ This does not inean that standard-setting organizations should never be forced to open their doors, however. While there are good reasons to limit the use of the essential facilities doctrine (which focuses on scale as such rather than exclusionary conduct), cases involving exclusionary conduct by competitors or a single firm seeking to obtain control of a highly standards-driven market may well warrant application of some antitrust rule, at least where the conduct appears likely to secure control of a market standard. ${ }^{182}$

In evaluating claims of anticompetitive exclusion from a standardsetting organization, the courts must take account of legitimate reasons proffered for the exclusion. ${ }^{183}$ There are unquestionably valid reasons to exclude a competitor from a group standard-setting organization, particularly if it is engaged in free riding on the cooperative efforts of the group ${ }^{184}$ or if it is unwilling to meet the reasonable technical or investment requirements of the group. ${ }^{185}$ On the other hand, restrictions based purely on the number or size of participants in a group seem more likely to mask a cartel, particularly in a network effects market, in which more participation is generally better from a societal perspective. And

180. See National Ass'n of Review Appraisers \& Mortgage Underwriters v. Appraisal Found., 64F.3d 1130, 1137 (8th Cir. 1995).

181. See James B. Kobak, Jr., Enforcers Focus on IP Issues, NAT'L L.J., May 6, 1996, at B7, B10. One way to avoid this result would be to compel competitor access only to the standard itself and not to the group producing the standard. See generally Joel R. Reidenberg, Governing Networks and Rule-Making in Cyberspace, 45 EMORY L.J. 911 (1996). This approach would have the advantage of requiring less government intrusion into the workings of the private group. Whether it would be effective, however, may depend on the complexity of the standards at issue and the potential for group members to obtain a lead-time advantage before the standard is announced.

182. The FTC seems to agree with this approach. See Anticipating THE 21st Century: Competition Policy in the New High-Tech, Global Marketplace, ch. 9, at 2-3 (1996).

183. See generally Pratt et al., supra note 166, at 553-57 (cataloging types of exclusionary bylaws).

184. Cf. Rothery Storage \& Van Co. v. Atlas Van Lines, 792 F.2d 210 (D.C. Cir. 1986) (holding that antitrust law did not prohibit restraints that eliminate the problem of free riders).

185. See Raymond T. Nimmer, Standards, Antitrust and Intellectual Property, in INTEllectual PROPERTY ANTITRUST 797, 830 (1995) ("As a general rule, standards derived and justified by attention to technical, rather than competitive motivations are not subject to antitrust problems even if they result in a disadvantage to one or several competitors."). Of course, it is by no means easy to distinguish legitimate technical concerns from barriers interposed for anticompetitive reasons. See Transamerica Computer Co. v. IBM Corp., 698 F.2d 1377 (9th Cir. 1983) (rejecting a claim that IBM has changed its technical interface standards in order to lock out competitors), and California Computer Prods. v. IBM Corp., 613 F.2d 727 (9th Cir. 1979) (rejecting a claim that IBM has changed its technical interface standards in order to lock out competitors). 
restrictions of the sort at issue in SCFC ILC v. Visa, which exclude particular competitors by name while allowing others, should be subject to the most exacting scrutiny.

Finally, some companies may attempt to manipulate the outcome of a standard-setting process by maneuvering the group into establishing a standard in which the company has a proprietary interest. ${ }^{186}$ The FTC made this allegation against Dell, ${ }^{187}$ and others have made it against Unisys. ${ }^{188}$ Where a party does attempt to capture a standard-setting process in this fashion, the potential anticompetitive consequences seem relatively clear: where network effects exist, controlling a market standard is substantially more lucrative than in ordinary markets because of the lock-in effects. Whether this is a problem best treated by antitrust, or instead by a rule of contract law, tort law, or estoppel, is another matter. $^{189}$

\section{Conclusions}

Because antitrust law is primarily concerued with market structure and conduct, it is heavily influenced by network economic effects. In various cases, network effects inay foreclose competition entirely or limit effective coinpetition to that occurring between members of the same network. Network effects inay have implications for the sorts of coinpetition-and cooperation-which antitrust law should and should not promote. Specifically, competition between different networks may

186. Capture of standard-setting organizations may also take the form of persuading a standardsetting body to refuse to allow a competitor's product to be certified for reasons other than the merits of the product. See Allied Tube \& Conduit Corp. v. Indian Head, Inc., 486 U.S. 492 (1988); American Soc'y of Mechanical Eng'rs v. Hydrolevel Corp., 456 U.S. 556 (1982); Radiant Burners, Inc. v. Peoples Gas Light \& Coke Co., 364 U.S. 656 (1961); David A. Balto, STANDARD-SETTING IN HIGHTECHNOLOGY INDUSTRIES (Working Paper, 1998). Cf. William J. Curran III, Volunteers ... Not Profiteers: The Hydrolevel Myth, 33 CATH. U. L. REv. 147 (1983) (criticizing the Hydrolevel decision).

187. In re Dell Computer Corp., No. 931-0097 (F.T.C. 1996).

188. See Lemley, Internet Standardization, supra note 46, at 1087-88 (discussing these allegations); see also Evans \& Reddy, supra note 89, at 17-18; James J. Anton \& Dennis A. Yao, Standard-Setting Consortia, Antitrust, and High-Technology Industries, 64 ANTITRust L.J. 247, 250 (1995).

189. See Lemley, Internet Standardization, supra note 46, at 1090-92 (discussing each possible alternative); McGowan, supra note II, at 840-41 (favoring contract alternative). A recent federal circuit case suggests that in the patent context at least, conduct of this sort may create a legal estoppel barring the patentee from enforcing the patent. In Wang Laboratories, Inc. v. Mitsubishi Electronics, Inc., 103 F.3d 1571, I580-82 (Fed. Cir. I997), cert. denied, 118 S. Ct 69 (1997), the court held that where Wang had sought to establish its patented product in the market as a standard by encouraging other companies (including Mitsubishi) to produce it, it was estopped from later suing Mitsubishi for infringement of that patent. It would not be too large a leap to extend this rationale to cases in which a patentee encouraged a standards group to adopt and use a standard without disclosing that the standard was proprietary. See also Stambler v. Diebold, Inc., 11 USPQ 2d 1709, 1714-15 (E.D.N.Y. 1988) (participant on standard-setting body who failed to mention patent covering the proposcd standard was estopped from later asserting that patent against members). 
be counterproductive in certain circuinstances. Network effects may also give rise to new types of opportunistic behavior that antitrust must police.

At the saine time, not all markets are in fact characterized by network effects. Courts must be vigilant against efforts by parties on either side of the dispute to use the rhetoric of network effects (or "increasing returns") in an effort to imfluence antitrust law. They should also give some thought to whether antitrust is always the right tool to use im network cases, a point to which we will return in Part III.

\section{B. Intellectual Property}

"[T]he key formula for the coming age is this: Open, good. Closed, bad."

Peter Schwartz \& Peter Leyden ${ }^{190}$

The nexus among intellectual property, compatibility, and network effects is quite strong. To the extent intellectual property rights confer ownership interests $\mathrm{m}$ a strong network standard, they may create durable market power in network markets. Conversely, as we suggested in Section II.A, the existence of compatibility between products or standards can in certain circumstances solve problems created by network effects. ${ }^{191}$ More generally, "the standard" that dominates a network effects market is not necessarily limited to one firm's product. For example, if one believes that QWERTY typewriter keyboards are dominant network standards, it does not follow that one firm dominates the typewriter imdustry, for the simple reason that no one owns the QWERTY standard, and anyone is free to produce it. Anyone who makes a typewriter keyboard with the same layout has made a compatible product that will share in whatever network benefits may exist. But if one firm owned the rights to produce keyboards with a QWERTY layout, it could exclude others from obtaining the benefits of the standard.

For these reasons, discussions of intellectual property and network effects have tended to focus on arguments that intellectual property rights should be limited in ways that promote compatibility between competing products im network effects markets. We identify and discuss three variants of this argument below.

\section{Arguments for Reverse Engineering}

The first, and most limited, argument in favor of compatibility in network industries would allow reverse engineering in order to achieve

190. Peter Schwartz \& Peter Leyden, The Long Boom, W1RED, July 1997, at 115, 173.

191. See supra notes 151-160 and accompanying text. 
compatibility. Reverse engineering is the process of taking a competitor's finished product and working backward to determine how it was made. ${ }^{192} \mathrm{~A}$ reverse-engineer can in theory do a variety of things with the information she obtains: duplicate the product, make a competing product that interoperates with the original product ("horizontal compatibility"), make a complementary product that works with the original product ("vertical coinpatibility"), or even publish the resulting inforination for use by others.

The legality of reverse engineering is determined by the relevant intellectual property regine. Trade secrets law allows reverse engineering of a publicly sold product, regardless of the purpose to which the resulting information is put. ${ }^{193}$ Indeed, Supreine Court precedent suggests that the rule permitting reverse engineering in trade secrets is the economic centerpiece of state trade secret law and the primary reason that trade secrets coexist peacefully with federal patent and copyright protection. ${ }^{194}$ By contrast, patent law provides no protection for those who reverse engineer a patented work: if they make, use, or sell the invention, even for commercial research purposes, they are liable for patent infringement. ${ }^{195}$ Copyright law occupies a curious middle ground. Until recently, copyright law "permitted" reverse engineering in a very functional sense- one could find the uncopyrightable ideas hidden in a book without copying the book, and therefore without triggering copy-

192. See Uniform Trade Secrets Act § 1, cmt. (1985); Restatement (ThIRD) OF UNFAIR COMPETITION LAW § 43, cmt. b (1995).

193. See Uniform Trade Secrets Act $\S 1$, cmt.

194. See Bonito Boats, Inc. v. Thunder Craft Boats, Inc., 489 U.S. 141, 160 (1989) (rejecting a state statute because it "prohibits the entire public from engaging in a form of reverse engineering of a product in the public domain. This is clearly one of the rights vested in the federal patent holder, but has never been a part of state protection under the law of unfair competition or trade secrets."); Kewanee Oil Co. v. Bicron Corp., 416 U.S. 470, 489-90 (1974) (patent and trade secret law can coexist because "[t]rade secret law provides far weaker protection in many respects than the patent law.... [T] rade secret law does not forbid the discovery of the trade secret by fair and honest means, e.g., independent creation or reverse enginecring...."). Curiously, the traditional rule permitting reverse engineering is absent from the Economic Espionage Act, the new federal criminal trade secrets statute, though it does not appear the omission was really considered or intended. See James H.A. Pooley et al, Understanding the Economic Espionage Act of 1996, 5 TEx. INTELl. Prop. L.J. 177, 195-97 (1997).

195. See 35 U.S.C. § 271(a) (1994); Robert P. Merges et AL., INTELlectual Property IN THE New Technological AGE 269-70 (1st ed. 1997) (discussing the limited nature of the experimental use defense); Rebecca S. Eisenberg, Patents and the Progress of Science: Exclusive Rights and Experimental Use, 56 U. CHI. L. Rev. 1017, 1018-19 (1989) (same). Whilc in theory the disclosure required by 35 U.S.C. $\S 112$ should reduce the need to reverse engineer a patented product, in practice there are several reasons why a competitor might necd to reverse engineer a patented product. First, she may need access to unpatented components of the same devicc. Second, the patent specification may not describe the invention in sufficient detail. See Fonar v. General Elec., 107 F.3d 1543 (Fed. Cir. 1997) (allowing broad functional descriptions of software). Finally, compatibility may require an exact picture of the interfaces between two products, and thus may require more detailed information than that the patentee is forced to disclose. 
right law at all. As copyrighted works are placed in digital form, this is changing-virtually every use of a digital work involves the making of at least one copy. ${ }^{196}$ In response to this change, which was first apparent in the context of computer programs, courts have created a limited right to reverse engineer a work (even though a copy is created) in order to extract uncopyrightable information from the work. ${ }^{197}$ But they have not adopted a universal right to reverse engineer for any purpose.

In network industries, there is a strong economic argument in favor of permitting reverse engineering in the limited set of cases in which it promotes either vertical or horizontal compatibility with an industry standard. Because products that can work with an industry standard are included in the network benefits of widespread adoption, broadly compatible products produced by competitors may allow the market to benefit from a universal standard, while permitting competition among providers of products incorporating that standard. For this reason, a number of economists have endorsed the development of a right to reverse engineer, at least in network markets. ${ }^{198}$ This is not necessarily a

196. See Jessica Litman, The Exclusive Right to Read, 13 CARDozo ARTs \& ENT. LJ. 29, 34-35 (1994); accord Jessica Litman, Revising Copyright Law for the Information Age, 75 OR. L. REv. 19, 21 (1996).

197. On the legality of reverse engineering in copyright law, compare DSC Comm. v. DGI Technologies, 81 F.3d 597, 601 (5th Cir. 1996), and Bateman v. Mnemonics, Inc., 79 F.3d 1532, 1539 n.18 (11th Cir. 1996), and Lotus Dev. Corp. v. Borland Int'l, Inc. 49 F.3d 807, 817-18 (1st Cir. 1995), aff'd, 516 U.S. 233 (1996), reh'g denied, 116 S. Ct. 1062 (1996), and Sega Enterprises Ltd. v. Accolade, Inc., 977 F.2d 1510, 1527-28 (9th Cir. 1992), and Atari Games v. Nintendo, 975 F.2d 832, 843-44 (Fed. Cir. 1992), and Vault Corp. v. Quaid Software, 847 F.2d 255, 270 (5th Cir. 1988), and DSC Comm. v. Pulse, 976 F. Supp. 359 (E.D. Va. 1997) (all endorsing a right to reverse engineer in some circumstances), and Mitel, Inc. v. Iqtel, Inc., 896 F. Supp. 1050, 1056-57 (D. Colo. 1995), aff'd, 124 F.3d 1366 (10th Cir. 1997) with Apple Computer v. Franklin Computer, 714 F.2d 1240, 1253 (3d Cir. 1983), and Digital Communications Assoc. v. Softklone Distributing Corp., 659 F. Supp. 449 (N.D. Ga. 1987) (older cases rejecting such a right). The weight of modern authority clearly supports a reverse engineering right. Most commentators are in agreement. See, e.g., BAND \& KATOH, supra note 80; J. Beckwith Burr, Competition Policy and Intellectual Property in the Information Age, 41 VILL. L. REV. 193 (1996); Julie E. Cohen, Reverse Engineering and the Rise of Electronic Vigilantism: Intellectual Property Implications of "Lock-Out" Programs, 68 S. CAL. L. REv. 1091 (1995) [hereinafter Cohen, Reverse Engineering]; Lawrence D. Graham \& Richard O. Zerbe Jr., Economically Efficient Treatment of Computer Software: Reverse Engineering, Protection, and Disclosure, 22 Rutgers Computer \& TECH. L.J. 61 (1996); Dennis S. Karjala, Copyright Protection of Computer Documents, Reverse Engineering, and Professor Miller, 19 U. DAYTON L. REv. 975 , 1016-18 (1994); Charles R. McManis, Taking TRIPs on the Information Superhighway: International Intellectual Property Protection and Emerging Computer Technology, 41 VILL. L. REv. 207 (1996); David A. Rice, Sega and Beyond: A Beacon for Fair Use Analysis ... At Least as Far as It Goes, 19 U. DAYTON L. REv. 1131, 1168 (1994). Other intellectual property statutes expressly include a similar right. See Semiconductor Chip Protection Act, 17 U.S.C. § 906 (1994); Brooktree Corp. v. Advanced Micro Devices, Inc., 977 F.2d 1555, 1565-67 (Fed. Cir. 1992) (discussing Act).

198. In addition to the legal commentators cited supra note 197, see, e.g., Jeffrey Church \& Roger Ware, Network Industries, Intellectual Property Rights and Antitrust Policy, in CoMPETITION Policy, 1NTellectual Property Rights and International Economic Integration (forthcoming 1997); William E. Cohen, Competition and Foreclosure in the Context of Installed Base and Compatibility Effects, 64 ANTITRUST LJ. 535, 550 (1996) ("Adoption of a competitive 
"pure" benefit to competition; rather, it foregoes competition in period one (the competition that would otherwise have occurred to set the de facto standard) im favor of competition in period two (among competing suppliers of standard-compatible products). ${ }^{199}$

Of course, im the peculiar economic circumstance that characterizes information markets, more competition may not always be better. Indeed, the principle behind intellectual property law is that competition should be sacrificed to some extent in order to give sufficient incentive for innovation. ${ }^{200}$ Some have argued that intellectual property owners should be given the right to prevent reverse engineering, because it would further increase their returns. ${ }^{201}$ However, it does not make economic sense to give complete control over information to owners of intellectual property. As Larry Lessig has put it, "[W]hile we protect real property to protect the owner from harm, we protect intellectual property to provide the owner sufficient incentive to produce such property. 'Sufficient incentive,' however, is something less than 'perfect control." "202 There is ample evidence that the goal of intellectual property law is to balance the incentives given to property owners against the harm experienced by consumers and next-generation competitors. ${ }^{203}$

compatibility standard can yield important network effects. It essentially gives consumers the benefit of other suppliers' networks."); Joseph Farrell, Standardization and Intellectual Property, 30 JuRIMETRICs J. 35 (1989); Katz \& Shapiro, Systems Competition, supra note 25, at 111.

199. See Katz \& Shapiro, Systems Competition, supra note 25, at 110-11.

200. See generally Mark A. Lemley, The Economics of Improvement in Intellectual Property Law, 75 Tex. L. REv. 989, 996-97, 1043 (1997) and sources cited therein; McGowan, supra note 11, at 773-77.

201. See, e.g., Anthony L. Clapes, Confessions of an Amicus Curiae: Technophobia, Law and Creativity in the Digital Arts, 19 U. DAYTON L. REv. 903, 934 (1994); Arthur R. Miller, Copyright Protection for Computer Programs, Databases, and Computer-Generated Works: Is Anything New Since CONTU?, 106 HaRv. L. Rev. 977, 1029-32 (1993).

202. Lawrence Lessig, Intellectual Property and Code, 11 St. John's J. Legal Comment. 635, 638 (1996).

203. See, e.g., Graham v. John Deere Co., 383 U.S. 1, 9 (1966) ("The patent monopoly was not designed to secure to the inventor his natural right in his discoveries. Rather, it was a reward, an inducement, to bring forth new knowledge."); Mazer v. Stein, 347 U.S. 201, 219 (1954) ("The economic philosophy behind the clause empowering... patents and copyrights is the conviction that ... [it] is the best way to advance public welfare ...."); Fogerty v. Fantasy, Inc., 510 U.S. 5I7, 524 (1994); Feist Publications v. Rural Tel. Serv., 499 U.S. 340, $349-50$ (1991); Stewart v. Abend, 495 U.S. 207, 225 (1990); Bonito Boats, Inc. v. Thunder Craft Boats, Inc., 489 U.S. 14I, 146 (1989); Sony Corp. of America v. Universal City Studios, 464 U.S. 417, 429 (1984); Twentieth Century Music v. Aiken, 422 U.S. 151, 156 (I975); Kewanee Oil Co. v. Bicron Corp., 416 U.S. 470, 476 (1974); Goldstein v. California, 412 U.S. 546, 559 (1973); United States v. Paramount Pictures, 334 U.S. 131, 158 (1948); 17 U.S.C. $\S 102$ (b) (1994) (idca-expression dichotomy); 17 U.S.C. $\$ 107$ (1994) (fair use doctrine); 17 U.S.C. $\S 108$ (1994) (right to make library copies); 17 U.S.C. § II0 (1994) (right to make certain miseellaneous copies and performances); 17 U.S.C. $\S 117$ (I994) (rights to copy computer software); 15 U.S.C. \$ 1125(c) (I994) (protections for news reporting and noncommercial use in federal dilution statute); 35 U.S.C. $\$ 112$ (1994) (requirement of public disclosure of patents); 1 Paul Goldstein, Copyright $\$ 1.14$, at 1:40 (2nd ed. 1998); L. Ray Patterson \& Stanley W. LiNDBerg, The NATURE OF CopYright 120-22 (199I); Cohen, supra note 197, at 1200; Dennis S. 
While one might dispute whether a perfectly formed intellectual property right includes a right to reverse engineer for any purpose, it seems fundamentally misguided to argue that courts should interpret a law like copyright-which withholds protection from certain types of information (ideas and facts, for example) precisely in order to make them available to the public-to prevent access to that information. ${ }^{204}$ The argument is even weaker in the context of strong network effects, where giving such power to the intellectual property owner converts an open, competitive standard into a proprietary de facto one, conferring an unexpected windfall on the intellectual property owner ${ }^{205}$ and reducing net social welfare.

The economic argument in favor of reverse engineering to achieve compatibility in network industries is relatively straightforward in theory. In practice, however, the arguinent is complicated by the fact that in some industries, particularly the software industry, reverse engineering is difficult. ${ }^{206}$ As a result, a right to reverse engineer a computer program will not necessarily prevent unilateral dominance of a network standard in a software market. The best example of this seems to be Microsoft's continued dominance of the operating systeins market in software. While the issue is uot entirely free from doubt, and certainly was not seven years ago, it now appears that a competitor could legally reverseengineer the current-generation Microsoft operating system, copy its functional components (at least to the extent they are necessary for compatibility), and build a competing, "Windows-compatible" operatmg system. So given the obvious network effects in this industry, why hasn't anyone done so? Or more accurately, given that some have done

Karjala, Federal Preemption of Shrinkwrap and On-Line Licenses, 22 U. DAYToN L. REv. 511, 512 (1997); Mark A. Lemley, Romantic Authorship and the Rhetoric of Property, 75 TEx. L. REv. 873, 888-90 (1997); Pierre N. Leval \& Lewis Liman, Are Copyrights for Authors or their Children?, 39 J. COPYRIGHT Soc'y 1, 3 (1991); Jessica Litman, The Public Domain, 39 Emory LJ. 965, 969 (1990); McGowan, supra note 11, at 773-777; Peter S. Menell, An Analysis of the Scope of Copyright Protection for Application Programs, 41 Stan. L. REv. 1045, 1082 (1989).

204. Cf. Robert A. Kreiss, Accessibility and Commercialization in Copyright Theory, 43 UCLA L. REV. 1, 5 (1995) (suggesting that copyright should be interpreted so as to permit public access to ideas once a work has been commercialized).

205. Katz \& Shapiro suggest an exception to this: "[S]ince systems competition is prone to tipping, there are likely to be strong winners and strong losers uuder incompatibility. Therefore, if a firm is confident it will be the winner, that firm will tend to oppose compatibility." Katz \& Shapiro, Systems Competition, supra note 25, at 111. While there is certainly historical evidence for this-such as the Bell System's refusal to interoperate with telephone competitors at the turn of the century when it had the largest but not yet a dominant market share-it seems unlikely that any company should be able to make such a prediction before developing an intellectual property right and therefore unlikely that its research investment decision will be adversely affected by a reverse engineering rule.

206. See, e.g, Andrew Johnson-Laird, Software Reverse Engineering in the Real World, 19 U. DAyton L. Rev. 843, 901 (1994) (reverse engineering software is technically difficult, timeconsuming, expensive, and yields imperfect results). 
so, ${ }^{207}$ why have they not succeeded in competing effectively with Microsoft? ${ }^{208}$

The answer is complex. ${ }^{209}$ Several factors have contributed to $\mathrm{Mi}$ crosoft's continued dominance. First, the legal environment surrounding such a reverse engmeering effort has been unclear until relatively recently. While it is now almost universally accepted that reverse engineering a computer program in order to obtain access to its unprotectable functional elements and application program imterfaces (APIs) does not violate the copyright laws, virtually none of the cases establishing this principle were decided before $1992 .{ }^{210}$ Further, Microsoft may have other legal means at its disposal to prevent such reverse engineering. For example, Microsoft has argued that each of the $100 \mathrm{mil}$ lion-plus copies of object code it sells are limited distributions of trade secret information subject to a "shrinkwrap license" agreement that prevents reverse engineering, and therefore that no one can obtain a copy of Microsoft's operating systems without "agreeing" not to reverse engineer it. ${ }^{211}$ More recently, Microsoft has begun to acquire

207. Both the IBM OS/2 operating system and the Linux operating system were capable of operating in a Microsoft Windows-compatible inode. For an entertaining description of the history of Linux, see Glyn Moody, The Greatest OS that (N)ever Was, WiREd, Aug. 1997, at 122.

208. See generally Rieko Mashima, The Turning Point for Japanese Software Companies: Can They Compete in the Prepackaged Soffware Market?, 11 Berkeley TECH. L.J. 429, 431 (1996) (attributing the failure of the Japanese mass-1narket software industry at least in part to network effects, which locked in the U.S. first entrants).

209. We would like to thank all those who lent us their technical expertise in evaluating this market, including Dale A.J. Dietrich, Mikus Grinbergs, Jessica Litman, and E.L. Oliver.

210. See supra note 197 (collecting cases on reverse engineering).

211. For an extreme version of this argument, see Ronald L. Johnson \& Allen R. Grogan, Trade Secret Protection for Mass Distributed Software, in 3 THE CLA COMPUTER LAW COMPANION 39 (Kyer \& Erickson eds., 1996); see also Robert W. Gomulkiewicz \& Mary L. Wilhamson, A Brief Defense of Mass Market Software License Agreements, 22 RuTGERS COMPUTER \& TECH. L.J. 335 (1996) (a inore limited defense of shrinkwrap licenses). The argument that Microsoft's object code remains a trade secret despite the distribution of many millions of copies flies in the face of the fundamental tenets of trade secret law. See Trandes Corp. v. Guy F. Atkinson Co,, 996 F.2d 655, 663 n.8 (4th Cir. 1993) (dictum); Religious Technology Center v. Lerma, 908 F. Supp. 1362, 1368 (E.D. Va. 1995) (discussing the availability of information on the Internet over 10-day period which destroyed trade secrecy); Young Dental Mfg. v. Q3 Special Prods., 891 F. Supp. 1345, 1350 (E.D. Mo. 1995) (characterizing as "completely frivolous" plaintiff's clain that its publicly sold software was a trade secret); MERGES ET AL., supra note 195, at 59-61, 856-858; cf. Metallurgical Indus. v. Fourtek, Inc., 790 F.2d 1195, 1200 (5th Cir. 1986) (considering whether a himited disclosure to two comparies defeated trade secret status); Data Gen. Corp. v. Digital Computer Controls, 297 A.2d 433, 436 (Del. Ct. Chanc. 1971), aff'd, 297 A.2d 437 (Del. S. Ct. 1972) (holding that distribution of approximately 500 copies of program did not destroy trade secrecy). In addition, there is a separate issue as to whether shrinkwrap licenses are enforceable contracts at all. Compare ProCD, Inc. v. Zeidenberg, 86 F.3d 1447, 1449 (7th Cir. 1996) (enforcing shrinkwrap license), and Maureen A. O'Rourke, Copyright Preemption After the ProCD Case: A Market-Based Approach, 12 BERKELEY TECH. L.J. 53, 57 (1997) (offering a limited defense of ProCD), with Morgan Labs, Inc. v. Micro Data Base Systems, 41 U.S.P.Q.2d 1850 (N.D. Cal. 1997) (holding shrinkwrap license ineffective to modify eontract terms), and Novell, Inc. v. Network Trade Center, No. 95 CV00523 (D. Utah 1997) (shrinkwrap licenses unenforceable), and Mark A. Lemley, Intellectual Property and Shrinkwrap 
patents governing APIs and similar interface technology. ${ }^{212}$ Unlike copyright and trade secret law, patent law has no reverse engineering defense. ${ }^{213}$ Thus, the legal climate regarding software reverse engineering has never been completely certain. This uncertainty can be used to great advantage by aggressive intellectual property plaintiffs.

Second, reverse engineering an operating system's program to achieve compatibility in a competing program is particularly difficult. The Microsoft operating systems are complex and interrelated to such an extent that it is not enough merely to build a few hooks into a prograin. Offering a competing program with the same functionality would require accurate replication of most, if not all, of Microsoft's subroutines. ${ }^{214}$ Microsoft has strategic incentives to take advantage of this complexity, both by including undocumented calls that may not be easily identifiable, and by playing on consumer fears of partial incompatibility.

Third, Microsoft regularly changes its operating system. It has upgraded its operating system software on a regular basis over the last 15 years and on several occasions has introduced an entire new generation of operating system, despite the difficulty of migrating the installed base of users from an old prograin to a new (albeit compatible) one. A competitor would have to reverse engmeer each new program and alter its own program to maintain compatibility with the new generation Microsoft product. Ideally, it would have to do it quickly, since even a six-month time lag in introducing a competing product can be fatal im a market which moves as fast as software. Regardless whether Microsoft deliberately introduced changes in its operating systems to deter competitors (such conduct may also be consistent with desirable product innovation), the evolution of its programs has had that effect.

Finally, Microsoft simply does not charge very much for its operating system. The price (about $\$ 99$ for an off-the-shelf copy) is unquestionably above marginal cost, as it is with all software protected by an intellectual property right, but it does not seem to reflect the full power of the network effects Microsoft has harnessed. A competitor

Licenses, 68 S. CAL. L. Rev. 1239, 1248-53 (1995) (noting that every other case before Pro-CD refused to enforce shrinkwrap licenses), and Niva Elkin-Koren, Copyright Policy and the Limits of Freedom of Contract, 12 Berkeley TECH. LJ. 93, 94 (1997) (criticizing the ProCD decision).

212. A Lexis search on August 4, 1997 revealed 22 patents assigned to Microsoft which dealt with APIs. Examples include U.S. Patent No. 5,590,347, for a "[m]ethod and system for specifying alternate behavior of a software system using alternate behavior indicia"; U.S. Patent No. 5,437,006, for a "[s]preadsheet command/function capability from a dynamic-link library"; and U.S. Patent No. $5,430,878$, for a "[m]ethod for revising a program to obtain compatibility with a computer configuration."

213. See supra note 195 and accompanying text.

214. See Hartz, supra note 76, at 21I-13 (describing this problem, and invoking Clarke's Law to suggest that a sufficiently hard problem of this sort might as well be impossible). 
simply may not find it worthwhile to expend the effort required to build and maintain a compatible operating systein, facing possible legal action, in order to sell its product at a relatively low price. This is especially true given Microsoft's history of competing for market share by lowering price (or even giving products away for free) when challenged. ${ }^{215}$

That reverse engineering is not a perfect route to interoperability may be either a good or a bad thing, depending on one's perspective. Those who worry that rapid imitation will leave little incentive for intellectual property owners to create new works may take some solace in the fact that reverse-engineers will have to spend time and money discovering the ideas contained in a new piece of software, giving some latitude to earn supracompetitive returns before the ideas are discovered. ${ }^{216}$ Network effects may actually enhance this technological first-mover advantage, because the tipping effect may produce a rapid supracompetitive return before imitators can effectively reverse engineer. ${ }^{217}$ Further, reverse engineering does not permit competition within a standard in all cases, which may add some further incentive to create new products, or at least to try to win a standards competition. ${ }^{218}$

The imperfection of reverse engineering as a device for opening standards to competition has negative consequences for consumers. If effective competition for a Microsoft-compatible operating system existed, the price of the operating system presuinably would fall, and more consumers would adopt the standard, to the benefit of all. Nonetheless, it appears that the threat of entry drives Microsoft to develop new product upgrades and to price its product at a fairly reasonable level. Perhaps even where the legality of reverse engineering does not lead to effective competition within a standard, it nonetheless operates as a constraint on the power that standard-setters would otherwise exercise in network industries.

215. See Peter H. Lewis, Microsoft to Give Away.Web Server Software, N.Y. Times, Feb. 6, 1996, at D6 (describing Microsoft's pricing policy regarding Web browsers).

216. See, e.g., Pamela Samuelson et al., A Manifesto Concerning the Legal Protection of Computer Programs, 94 Colum. L. Rev. 2308, 2430 (1994) (arguing that if reverse engineering were cheap and easy, insufficient incentive might be provided to software developers; and making a parallel argument for desigu know-how that is readily apparent from a casual inspection of the program).

217. See Colien, supra note 198, at 541 ("network effects can be siguificant sources of firstmover advantage").

218. Indeed, some companies luave gone to the extreme of making their own product incompatible with itself, precisely in order to make copying less lucrative. See, e.g., David Lazarus, DVD's World (and Welcome to It), WIRED, July 1997, at 42 (noting that manufacturers of digital versatile discs have made different, incompatible disks for marketing in different parts of the world). From a social welfare perspective, this is disastrous in a network market. That the companies involved are willing to forego efficiencies of product and, in all likelihood, market share suggests precisely how concerned they are about easy imitation of their products. 


\section{Arguments Against Protecting Interface Components}

In part because reverse engineering is not a perfect solution to the problem of standards dominance, a number of commentators have argued that intellectual property should not protect program elements that control the interface between components at all, allowing unlimited access to such components by competitors. ${ }^{219}$ More generally, to the extent the existence or scope of an intellectual property right $\mathrm{m}$ a standard is undetermined, courts have considered network effects in deciding whether or not to grant a new or stronger form of intellectual property protection to the standard-setter. ${ }^{220}$

The bellwether case for software interface components was Lotus Development Corp. v. Borland International. ${ }^{221}$ Stripped to its essence, the case involved a copyright dispute between first- and secondgeneration spreadsheet vendors over the ability of the first-generation developer to control the program and user interfaces of the spreadsheet. The very basic, pre-Windows Lotus 1-2-3 interface involved two lines of word commands that appeared on each screen at any given time, and which were part of an overall menu structure or hierarchy. The total number of commands in the menu command hierarchy was 469; all the commands were intuitive one-word mstructions like "Graph" and "Print." Borland's Quattro Pro spreadsheet, by contrast, was a more sophisticated, Windows-based program with a much more detailed user interface. Lotus sued Borland because the Quattro Pro spreadsheet included within it "Key Reader" features that allowed users to run their own 1-2-3-based macros in Quattro Pro, and an "Emulation Mode" that allowed users to use 1-2-3 commands to operate the Quattro Pro spreadsheet.

The district court found that the overall menu command hierarchy (and at least some of its constituent elements) was copyrightable, and that Borland necessarily copied that hierarchy in both the Emulation

219. See, e.g., Farrell, supra note 152, at 369-70; Peter S. Menell, An Analysis of the Scope of Copyright Protection for Application Programs, 41 STAN. L. REv. 1045, 1066-72 (1989); Peter S. Menell, The Challenges of Reforming Intellectual Property Protection for Computer Software, 94 Colum. L REv. 2644, 2652-53 (1994).

220. The clearest example is United States Golf Association v. St. Andrews Systems, 749 F.2d $1028,1037-41$ (3d Cir. 1984), where the court rejected the USGA's claim to own a property right in its standard handicapping system. Other cases exist in the computer industry, however. See infra notes 221-241 and accompanying text.

221. 49 F.3d 807 (1st Cir. 1995), aff'd by equally divided Court, 116 S. Ct. 804 (1996). The case has been discussed in a great deal of factual detail elsewhere; we will not repeat this background here. See, e.g., Glynn S. Lunney, Jr., Lotus v. Borland: Copyright and Computer Programs, 70 TuL. L. REv. 2397 (1996); David R. Owen, Interfaces and Interoperability in Lotus v. Borland: A MarketOriented Approach to the Fair Use Doctrine, 64 FordHAM L. Rev. 2381 (1996). 
and Key Reader features. ${ }^{222}$ The First Circuit reversed, with the majority ruling broadly that Lotus' menu command hierarchy was not copyrightable at all because it was a "method of operation" of the 1-2-3 program. ${ }^{223}$ Judge Boudin, concurring, offered an alternative rationale, one at least implicitly based in network effects. In his view, the key to the case was that Borland was not seeking to trade on Lotus' contributions, ${ }^{224}$ but merely to assist the user in migrating her data from 1-2-3 to Quattro Pro and to prevent her from being "locked in" by her investment in learning the 1-2-3 program. ${ }^{225}$

Argument in Lotus focused a great deal of attention on the network effects of Lotus 1-2-3's original dominant market position. A prominent group of economics professors took the unusual step of filing an amicus brief with the Supreme Court in the case. ${ }^{226}$ They argued that computer program interfaces exhibited strong network effects:

Network effects are important in software markets. Users want to share data files and programs such as macros; they want to work on machines owned by others; they want access to a wide selection of complementary products (including third-party manuals, consulting services, training courses, and add-on software). Certain aspects of programs must be identical in order for users of different programs to share these network benefits; these aspects will predictably include "interfaces" and aspects of a program that define a language, such as a macro language. ${ }^{227}$

These problems could be solved, in the economists' opinion, by allowing competitors to use the program interfaces:

Whether or not network effects and switching costs limit competition depends crucially on whether or not vendors have proprietary control of the interfaces. If interfaces are public, competitors can make their products compatible, and users will be able to choose a program on the basis of its quality and price rather than on switching costs and installed base of users. If interfaces are protected by copyright, the copyright holder can prevent competitors from making their products coinpatible. In

222. The district court's decisions are reported at Lotus Development Corp. v. Borland International, Inc., 788 F. Supp. 78 (D. Mass. 1992); 799 F. Supp. 203 (D. Mass. 1992); 831 F. Supp. 202 (D. Mass. 1993); and 831 F. Supp. 223 (D. Mass. 1993).

223. See 49 F.3d at 819.

224. See id. at 821 (Boudin, J., concurring) ("Borland's use is privileged because ... it is not seeking to appropriate the advances made by Lotus' menu.").

225. See id. See also Hamilton \& Sabety, supra note 34, at 274-75. Hamilton \& Sabety endorse this result, noting that giving Lotus the "capacity to block a migration path for software consumers is anticompetitive rather than the result of a legitimate copyright monopoly." Id. at 275.

226. See Lotus Dev. Corp. v. Borland Int'l, Inc., Brief Amicus Curiae of Economics Professors and Scholars in Support of Respondent, No. 94-2003.

227. Id. at 7 (citations omitted). 
this way the intellectual property treatment of interfaces crucially affects the nature of competition. ${ }^{228}$

Others have made similar arguments against protecting program interfaces, both in briefs and in academic commentary. ${ }^{229}$

This argument is attractive for the same reasons as arguments in favor of allowing reverse engineering: both would permit competitors to build different but interoperable programs, effectively opening de facto standards to competition in the same way that an open standard-setting group permits competition in products within the standard. Competition means that price declines toward marginal cost, increasing efficiency and inducing more people to join the network standard to the benefit of all. ${ }^{230}$ If this is the goal, though, we ought not limit ourselves to copyright. Program interfaces might also be locked up by being patented, or by being kept secret from competitors, as seems to have been the case with Microsoft's operating system. If we were truly to permit competition within de facto standards, we would have to deny all forms of intellectual property protection to the interfaces that allow access to such standards. ${ }^{231}$

Yet interfaces themselves may exhibit the market failures that justify intellectual property protection. If interfaces are excluded from intellectual property protection entirely, it is possible that companies will not invest time or effort to develop them. ${ }^{232}$ This is particularly likely if

228. Id. at 11 .

229. See, e.g., Mitel, Inc. v. Iqtel, Inc. 896 F. Supp. 1050, 1056 (D. Colo. 1995), aff'd, 124 F.3d 1366 (10th Cir. 1997); Dennis S. Karjala \& Peter S. Menell, Brief Amicus Curiae: Applying Fundamental Copyright Principles to Lotus Dev. Corp. v. Borland Int'l, Inc., 10 High TECH. LJ. 177, 178 (1995); Farrell, supra note 152, at 9-10; Hamilton \& Sabety, supra note 34, at 274-77. Cf. Stephen M. McJohn, Fair Use of Copyrighted Software, 28 RuTGERS LJ. 593, 634-35 (1997) (arguing for a stronger fair use defense in software cases). But see David Friedman, Standards as Intellectual Property: An Economic Approach, 19 U. DAYTon L REv. 1109, 1110-11 (1994) (suggesting that proprietary control over market standards should not be considered problematic).

230. See Farrell, supra note 152, at 3.

231. See Robert J. Levinson, Concerns Raised by Recent Software-Related Antitrust Cases, 41 ANTITRUST BuLL. 43, 48 (1996) (suggesting a regime in which intellectual property law does not prohibit competitors from creating software compatible with existing standards); Cohen, supra note 197, at 1168-81 (arguing against broad patentability of program interface standards and "Iock-out" devices); Lemley \& O'Brien, supra note 36, at 301-03 (arguing that patent law should be stricter toward attempts to patent simple interface connections).

Alternatively, one could endorse a system of compulsory licensing at a government-set rate, allowing some compensation to the owners of the standard but preventing them from denying access to the standard. See Peter S. Menell, Intellectual Property: General Theories, in THE New Palsgrave Encyclopedia of LaW aNd Economics 11 (forthcoming 1998) ("[c]ompuIsory licensing may be justified in particular circumstances to enable the full realization of network externalities"). Compulsory licensing has its own set of problems, however, which are treated elsewhere.

232. See Friedman, supra note 151, at 1121; Kenneth W. Dam, Some Economic Considerations in the Intellectual Property Protection of Software, 24 J. LEGAL. STuD. 321, 338 (1995). Friedman is probably wrong to suggest that investment in making an interface into a standard should be rewarded, 
the interfaces at issue are coinplex and difficult to design, as is often the case with computer software. ${ }^{233}$ An example of this difficulty is the First Circuit's result in the Lotus case itself. While it may make good economic sense to allow a transformative inprover like Borland to build on the Lotus 1-2-3 template, thus allowing existing 1-2-3 users to migrate without incurring significant switching costs, the court's opinion would also exempt from liability a "clone"-maker like Paperback Software, which did nothing but imitate the Lotus user interface and menu command hierarchy. ${ }^{234}$ The equities of the two cases seem very different, largely because Borland invested in improving rather than merely copying the Lotus interface. ${ }^{235}$ One might conceive of Paperback's clone copy as a beneficial effect of opening the standard to competition. The problem is that, at least in this case, virtually all of the value Lotus added is contained in the interface the court declares unprotectable.

One might rebut the traditional case for intellectual property in network inarkets, however, if one can deinonstrate that the network effects themselves will ensure an adequate return to the initial creator even absent intellectual property protection. The arguinent would be that the creator of a program component in a network narket will benefit from the additional adoptions caused by unauthorized copying, because it increases the chance the component will becoine a standard, and increases the value to existing consumers of using the creator's product. Some economists have indeed inade this arguinent. ${ }^{236}$ The argument seems best suited to circumstances in which copying is inperfect, or at least costly, such as reverse engineering. If copying were cheap and

however. See Friedman, supra note 151, at 1121-22. Not only will effort invested in market share be its own reward if the standard-setter has proprietary control over the standard, but experience in a number of industries has shown that investment by a single firm in determining a standard may be unnecessary, since if the putative standard is opened to competitors it may actually do better than other, competing standards that are closed. The success of IBM-compatible PCs and VHS VCRs are well-known examples.

233. For example, the authors of the Manifesto worry that program design information will be underproduced because current copyright law gives insufficient protection to such information. See Samuelson et al., supra note 216, at 2398-99. See also Baseman et al., supra note 73, at 270 (1BM spent $\$ 2$ billion developing OS/2). But see Leeds, supra note 158, at 656 (suggesting that consumer brand identification may mean that first-movers still retain advantages, and therefore that there may still be sufficient incentives to invest in developing new standards).

234. See Lotus Dev. Corp. v. Paperback Software Int'1, 740 F. Supp. 37 (D. Mass. 1990).

235. See Lemley, supra note 200, at 1079-81; Mark A. Lemley, Convergence in the Law of Software Copyright?, 10 HIGH TEсH. L.J. 1, $31-32$ (1995); McGowan, supra note 11, at 848 n.310; Owen, supra note 221, at 2418-23 (all making this point).

236. See Lisa N. Takeyama, The Welfare Implications of Unauthorized Reproduction of Intellectual Property in the Presence of Demand Network Externalities, 42 J. InDus. EcoN. 155 (1994). 
easy, and if there were no first mover advantages, ${ }^{237}$ it is hard to see how the original creator could capture any benefit from the adoption of her product as a standard.

A more general problem with eliminating intellectual property protection for interfaces is that it is far from clear that all or even most computer programs are standards in network effects markets. The operating system market for personal computers seems characterized by network effects, as discussed above. ${ }^{238}$ Peter Menell has also argued that user interfaces exhibit network effects, since people want to use a single, standardized interface with which they are already familiar; ${ }^{239}$ at least one court has endorsed his view. ${ }^{240}$ The nature of the network effect is different in the two markets, however: operating systeins exhibit network effects because application programmers need to write compatible software, while user interfaces exhibit only the "learning effect" of saving users from having to learn how to operate multiple systems. And there may well be program interface components that do not exhibit network effects at all. A rule precluding protection for program interfaces in every case cannot be justified by network effects if those effects are not themselves present in every case. A more nuanced approach, like the one suggested above that distinguishes the Borland and Paperback cases, seems warranted. Indeed, Menell himself has acknowledged as much in his later work. ${ }^{241}$

Evidence of such a nuanced approach can be found in a nonsoftware case involving the proposed extension of intellectual property law to protect a standardized golf handicapping system. In United States Golf Association v. St. Andrews Systems, ${ }^{242}$ the USGA, the "governing body of amateur golf in the United States,"243 sought intellectual property protection for its formula for equalizing competition among golfers of different skill levels by assigning a "handicap" score to each. The defendant, Data-Max, developed a computer program that calculated a golfer's USGA handicap. The court disposed readily of USGA's

237. For a discussion of first-mover advantages in the software context, see Lemley \& $O^{\prime} B$ rien, supra note 36 , at $274-75$.

238. See supra notes 71-82 and accompanying text. See also Peter S. Menell, Tailoring Legal Protection for Computer Software, 39 STAN. L. Rev. 1329, 1357-58 (1987).

239. See Peter S. Menell, An Analysis of the Scope of Copyright Protection for Application Programs, 41 Stan. L. Rev. 1045, 1066-71 (1989).

240. See Apple Computer v. Microsoft Corp., 799 F. Supp. 1006, 1025 (N.D. Cal. 1992), aff'd, 35 F.3d 1435 (9th Cir. 1994).

241. See Menell, supra note 219, at 2647-48 ("Intellectual property protection plays a critical role in determining the size and quality of these networks. Software products or attributes affecting the size of networks should, therefore, not generally receive intellectual property protection unless they require significant research efforts.") (emphasis added). Of course, determining ex ante which inventions meet this test has not proven to be an easy task.

242. 749 F.2d 1028 (3d Cir. 1984).

243. Id. at 1030 . 
trademark infringement claim, finding that the formula was functional and hence not itself capable of trademark protection. ${ }^{244}$ The most interesting part of the opinion was a thoughtful discussion of USGA's argument that the common law tort of misappropriation ought to be extended to cover Data-Max's conduct. ${ }^{245}$ The court refused to extend the doctrine beyond the classic case of direct competition. It reasoned:

The public acceptance of the U.S.G.A.'s handicap formula stems from the golfing public's desire to have a uniform system of quantifying recent performances in a way that will allow equitable competition among golfers of differing abilities. The U.S.G.A., in furtherance of its role as the governing body of amateur golf, has provided such a system and, in the absence of a better systein, the public has apparently accepted it. Under this state of affairs, the emergence of a single standard becoines largely a function of the need for uniformity. To require DataMax to use a different fornula would effectively destroy its ability to provide a handicapping service, since the U.S.G.A. formula is widely accepted by the golfing public. The purpose of a handicap is comparison between golfers, and handicaps based on different formulas cannot be readily compared.

Because the U.S.G.A. formula is the equivalent of an "industry standard" for the golfing public, preventing other handicap providers from using it would effectively give the U.S.G.A. a national monopoly on the golf handicapping business. Where such a monopoly is unnecessary to protect the basic mcentive for the production of the idea or inforination involved, we do not believe that the creator's interest in its idea or information justifies such an extensive restraint on competition. This case provides a good example of why such a restraint would harm the golfing public. Data-Max has expended time and creative energy in devising its own products and services. It has not only created the program used to calculate handicaps by coinputer, but has devised a handicapping service which improves on that provided by the U.S.G.A., at least to the extent that DataMax provides a golfer with a fresh handicap faster than the U.S.G.A. does. In addition, the U.S.G.A. has not been completely deprived of the opportunity to be coinpensated for its "good will" in connection with the handicap formula. To the extent that the approval of the U.S.G.A. would enhance the value of "instant handicaps," the U.S.G.A. has an opportunity, if it

244. See id. at 1034.

245. Whether state-law misappropriation doctrine could be extended in the face of federal preemption is a different question than the one the court addressed. On this issue, see NBA $v$. Motorola, 105 F.3d 841 (2d Cir. 1997) (only a limited misappropriation doctrine survives preemption). 
wishes to exercise it, of offering either Data-Max or rival the use

of the U.S.G.A. name in marketing its products and services. ${ }^{246}$

This seems to us to be the right approach. The Court bases its argument in this case on network effects but limits the discussion to a specific factual situation similar in certain respects to the Lotus case. It is also similar to Lotus in another respect: in both cases, the court was asked to rule on a novel issue of intellectual property law. It is much more difficult to find a case considering network effects arguments as a reason to depart from or modify established intellectual property law.

\section{Compatibility as an Antitrust Issue}

An alternative approach to these issues involves the application of antitrust (or analogously, misuse) law to computer markets that exhibit network effects. Not surprisingly, in light of what we have seen in antitrust law, ${ }^{247}$ network effects arguments in intellectual property have been Inost successful when presented in an antitrust context. We have already seen one specialized example-the Dell Computer case, in which the FTC blocked what it viewed as the strategic assertion of intellectual property rights to control a standard-setting organization. ${ }^{248}$ But there are other examples of cases in which the government used its antitrust power to compel interoperability or the licensing of intellectual property. ${ }^{249}$ Virtually none of these involve "compulsory licensing" of intellectual property in a strict sense; rather, they involve governmentimposed conditions on a merger of two companies. ${ }^{250}$

While the government has argued few of these cases on network effects grounds, the license imposed by consent decree in In re Silicon Graphics, Inc. ${ }^{251}$ is expressly based on the Federal Trade Commission's concern that once Silicon Graphics had acquired software makers Alias and Wavefront:

entry [into the market for workstations running entertainment graphics software] would be unlikely. Marketing a technically comparable or even an improved combination of non-SGI workstations with entertainment graphics software, other than that of

246. United States Golf Assoc. v. St. Andrews Systems, 749 F.2d 1028, 1040-41 (footnotes omitted).

247. See supra notes 68-189 and accompanying text (noting the widespread use of network effects arguments in antitrust cases).

248. See In re Dell Computer Corp., No. $931-0097$ (F.T.C. 1996).

249. See, e.g., United States v. Thomson Corp., 949 F. Supp. 907 (D.D.C. 1996) (conditioning Thomson's purchase of West Publishing Corp. on West's agreement to license its (allegedly copyrighted) pagination system to conpetitors); James P. Love, A Free Trade Area for the Americas: A Consumer Perspective on Proposals as they Relate to Rules Regarding Intellectual Property (visited Jan 7, 1998) <http://www.cptech.org/pharm/belopaper.html> (collecting cases).

250. See id.

251. No. C-3626 (F.T.C. Nov. 14, 1995). 
Alias or Wavefront, would be difficult, time consuming, and not likely to occur because of the extensive installed user base of SGI workstations with Alias, Wavefront and SoftImage entertainment graphics software. ${ }^{252}$

The Commission's solution to this network effect was to compel the licensing of the Alias and Wavefront software on nondiscriminatory terms. ${ }^{253}$ In dissent, Commissioner Starek suggested that requiring nondiscriminatory licensing is problematic, pointing to the crosssubsidization problems encountered in United States v. AT\&T. ${ }^{254}$ While Commissioner Starek was certainly correct that requiring licensing of intellectual property on nondiscriminatory terms is not problem-free and may require continued regulatory oversight, it does not follow that it is never an appropriate antitrust remedy. In particular, the majority in Silicon Graphics reasoned that allowing the vertical combination of SGI with the two software firms (and hence the horizontal combination of Alias and Wavefront themselves) produced substantial market efficiencies. ${ }^{255}$ The FTC's remedy arguably preserved those efficiencies while opening the standard to effective competition. ${ }^{256}$

Even where the government does not bring an action against merging firms or standard-setting groups, the existence of open license policies may play a role in avoiding antitrust scrutiny. For example, the Department of Justice recently cleared a potentially troubling pool of patents relating to video data compression, even though the patents would be licensed only as a group. Joel Klein, the head of the antitrust division, noted that "the proposal does not appear to have an anticompetitive effect on rivals because the license will be available to all applicants on the same terms and conditions."257

Another approach to the same issues can be found in the patent and copyright misuse doctrines. In part because of their flexibility-the

252. Id. at 4 .

253. See id.

254. 552 F. Supp. 131 (D.D.C. 1982) cited in No. C-3626, (F.T.C. Nov. 14, 1995) at 4 \& n.9 (Starek, Comm'r., dissenting).

255. Id., at 4.

256. By contrast, Commissioner Azcuenaga in her separate dissent would have blocked the merger of Alias and Wavefront with Silicon Graphics on the grounds that combining Alias and Wavefront increased the horizontal market power of the combined firm. See id., dissent at 1 (Azcuenaga, Comm'r., dissenting). This alternative remedy would have dealt with concerns about the market power produced by a combination, but would not have captured whatever network efficiencies were attributable to the proposed merger. A virtually identical case-with a similar result, and the same split among the commissioners-is In re Cadence Design Systems, No. 971-0033 (F.T.C. 1997).

257. Division Clears Patent Pooling, Licensing for Compressed Video Data, ANTITrust \& TRADE REG. RPT., July 10, 1997, at 31. See also Leeds, supra note 158, at $641-42$ (describing antitrust scrntiny of the DVD consortium, with the same result). 
copyright misuse doctrine has no statutory bounds, ${ }^{258}$ and the patent misuse doctrine has only a set of specific limitations rather than a general statutory scope $\mathrm{e}^{259}$ - the misuse doctrines may be well-suited to limiting the reach of intellectual property law in network cases. Indeed, Julie Cohen has argued for a misuse-based limit on both patented and copyrighted "lockout" devices that is distinct from the antitrust principles norunally applied in misuse cases. ${ }^{260}$ The Fifth Circuit adopted such an approach in DSC Communications v. DGI Technologies. ${ }^{261}$ In that case, the court held that it would likely be copyright misuse for DSC to assert that any testing of microprocessor cards by a competitor infringes its copyright on the microcode contained in those cards. ${ }^{262}$ The court found that DSC was "attempting to use its copyright to obtain a patentlike monopoly over unpatented microprocessor cards"263 by locking out competitors from producing and testing compatible cards. There is no indication in DSC that the decision is based on network effects, but it seems clear that the court was willing to apply misuse doctrine to protect reverse engineering in order to achieve system compatibility. It would certainly be possible to tailor this approach, finding misuse only where an intellectual property owner attempted to use the law to lock up access to a network standard. ${ }^{264}$

One can agree or disagree with the Commission's assumption in Silicon Graphics that the market for entertainment graphics software is characterized by strong network effects, so that locked-in consumers

258. See Lasercomb America v. Reynolds, 911 F.2d 970, 973 (4th Cir. 1990) ("[A] misuse of copyright defense is inherent in the law of copyright just as a misuse of patent defense is inherent in patent law.").

259. See 35 U.S.C. § 271(d); see generally Mark A. Lemley, Comment, The Economic Irrationality of the Patent Misuse Doctrine, 78 CALIF. L. REv. 1599, 1610 (1990) (commenting on the odd codification of the patent misuse doctrine).

260. See Cohen, supra note 197, at 1190-98. But see Marshall Leaffer, Engineering Competitive Policy and Copyright Misuse, 19 U. DAYTON L. REv. 1087, 1104-06 (1994) (arguing that copyright misuse should not protect efforts to reverse engineer). $C f$. RoBert P. MERGES, PATENT LAW AND Policy 1183-87 (2d ed. 1997) (noting possible scope for the patent misuse doctrine outside the bounds of antitrust law).

261. 81 F.3d 597, 601 (5th Cir. 1996).

262. The testing was argued to be copyright infringement because it made a temporary "copy" of the copyrighted code in RAM memory. See MAI Sys. v. Peak Computing, Inc., 991 F.2d 511, 518 (9th Cir. 1993). The DSC decision suggests that the Fifth Circuit would not agree with the MAI court's interprctation of the copyright laws.

263. 81 F.3d at 601 .

264. As some commentators have noted, the remedy imposed in misuse cases-refusing to enforce the intellectual property right-makes no economic sense. See Lemley, supra note 259, at 1614-20; Church \& Ware, supra note 198, at 34-35. But the limited, quasi-equitable nature of the remedy might actually be advantageous in network cases. If an intellectual property right is unenforceable only in the circumstances in which it is used to capture control over a network standard, access to the standard might be preserved without either punishing the intellectual property owner under antitrust law or depriving it of all use of its intellectual property. $C f$. Cohen, supra note 197, at 1193 (suggesting modification of the patent misuse remedy along similar lines). 
will be unlikely to switch to competing software. Certainly the Commission's opinion does not provide much detailed economic evidence in support of this conclusion. One can similarly disagree about the wisdom of applying misuse doctrine in any given case. But the critical point about the Silicon Graphics and DSC cases is that approaching these issues using the detailed factual economic analysis that should characterize misuse or fair use inquiries is preferable to resting on the more general principle that the intellectual property laws contemplate the possibility of supracompetitive returns. ${ }^{255}$ There is no general requirement in antitrust law that the owner of an intellectual property right make it available to potential competitors, even when the intellectual property owner is in a position of market power. ${ }^{266}$ One can disagree about whether such an obligation is ever appropriate in a specific case. ${ }^{267}$ But rule of reason methodology-essentially the approach embodied in Judge Boudin's concurrence, though under a different rubric-avoids the problem the First Circuit confronted in the Lotus case: how to craft an intellectual property rule that will enhance social welfare in network effects cases without inflicting too much damage on the fundamental tenets of intellectual property law in the majority of cases where network effects do not play a role.

\section{Conclusions}

Several things are worth noting about the role network effects have played in intellectual property arguments. First, unlike the antitrust cases, network effects arguments in intellectual property cases are virtually all on one side of the dispute-the defendant's. To date, no one has made an argument for expanded intellectual property protection based on network effects. ${ }^{268}$ Second, network economics has not penetrated as far into legal doctrine in intellectual property as it has in antitrust law. Though a number of cases have adopted legal rules based explicitly on

265. See Data Gen. Corp. v. Grumman Sys. Support, 36 F.3d 1147, 1187 (1st Cir. 1994) (establishing a rebuttable presumption against finding an antitrust violation on the basis of a refusal to license intellectual property, but noting that "there may be rare cases in which imposing antitrust liability is unlikely to frustrate the objectives of the Copyright Act"). Id. at n.64. Band and Katoh suggest that de facto standards in network effects markets ought to be considered one of these "rare cases." See BAND \& KaToH, supra note 80 , at 47.

266. See, e.g., Data Gen. Corp., 36 F.3d at 1188; Berkey Photo, Inc. v. Eastman Kodak Co., 603 F.2d 263, 283 (2d Cir. 1979). But see Leeds, supra note 158, at 658 (suggesting that the reasoning of Berkey Photo "breaks down in the presence of network externalities").

267. Indeed, we have. Compare McGowan, supra note 11, at 850 ("[T] he essential facilities doctrine has no place in the legal regime being crafted to regulate software," at least given the legality of reverse engineering), with Lemley, Internet Standardization, supra note 46, at 1084-86 (arguing that while essential facilities doctrine should be rarely used, it may be appropriate in some cases).

268. A few commentators have suggested that strong property rights were still appropriate in such markets, however. See Dam, supra note 232, at 372; Friedman, supra note 151, at 1117. 
their consideration of network effects, these all exist at the margins of intellectual property law-where an argument is made for expanding intellectual property rights beyond their existing boundaries, or at least where the scope of those rights has not yet been determined. Even the one case that might be said to cut back on well-established legal protection, Lotus v. Borland, involved what the court perceived to be a novel, unresolved legal issue. That network effects arguments are most successful only at the margins of intellectual property law may suggest that courts hearing intellectual property cases have not integrated economic thought into their decision-making process as thoroughly as in antitrust law. That a major use of network effects arguments in intellectual property cases has been in the antitrust and misuse contexts further bolsters this view.

\section{Government Standard-Setting ${ }^{269}$}

We have so far discussed industries in which standards either emerge from competition to set them, or in which standards are set or encouraged by private organizations that exist for that purpose. An alternate possibility is that the government might identify and set the appropriate standards and compel all participants in the market to comply. The government does this from time to time. ${ }^{270}$ For example, the Federal Communications Commission sets standards for interconnection between telephone networks and standards governing the use of products that might interfere with broadcast communications. ${ }^{271}$ More recently, the United States government stepped into the debate over the proper standard for high definition television (HDTV), selecting a standard that unified U.S. development work bnt was at odds with other standards adopted in Japan and Europe. ${ }^{272}$ And government agencies such as the Advanced Research Projects Agency and the National Science Foundation played a role in the development of the Internet, including the creation of Internet interconnection protocols. Indeed, private Internet standard-setting groups such as InterNIC and the IETF were once governinent-sponsored standards organizations. ${ }^{273}$ Government-set standards have some of the same appeal as those set by private organiza-

269. This section elaborates issues first introduced in Lemley, Internet Standardization, supra note 46 , at $1062-64$.

270. See Andrew Updegrove, Consortia and the Role of the Government in Standard Setting, in STANDARDS POLICX FOR INFORMaTION INFRASTRUCTURE, supra note 152, at 321.

271. See F.C.C. Rules, 47 C.F.R. $\$ 68.1$.

272. See Denise Caruso, Debate Over Advanced TV Gives the F.C.C. a Chance to Be Assertive, N.Y. Trmes, June 17, 1996, at D5; F.C.C. Proposes Standards for Digital Television, N.Y. Times, May 10,1996 , at D4.

273. Government may also play a standard-setting role as a market participant, since it is often one of the largest customers of a given product. In most instances, however, this public procurement does not create the same problems as government-mandated standards. 
tions: a wasteful competition to set a de facto standard is avoided, and the government can presumably mandate open access to the technical interface, permitting competition within the standard.

Whether government standard-setting is a good idea or a bad idea depends on the characteristics of the market. In some industries, it is critical that a simgle standard be set immediately, almost without regard to what that standard is. Where the need for a high degree of uniformity in adoption of a standard comcides with the technical simplicity of the standard, government action may sometimes be desirable. Consider roads. Whether all traffic should drive on the left or the right is essentially an arbitrary decision. It is far more important that everyone obey the same rnle than that the "best" side be chosen. While it is certainly possible to let the market solve this problem by means of a standards competition -in which cars optimized for either left- or right-side driving win out through the tipping effect-the social cost of holding such a competition would be quite large. A governmentally set standard is preferable $m$ this instance because the precise standard chosen does not matter very much, and the government can impose various legal sanctions (including criminal ones) to enforce uniform compliance with the standard.

Of course, not all networks share these characteristics. There are several reasons why government control of the standard-setting process should not be encouraged in the ordinary case, in which the choice of standard makes a difference for social welfare. First, government agencies are generally composed of career public servants, not market participants. As a result, these agencies may not involve the most knowledgeable individnals in the standard-setting process. ${ }^{274}$ This is an inherent danger of bureaucracy, particularly when it attempts to regulate such a fast-moving area of cominerce as the Internet. Government standard-setting groups may be slow and may not always have access to the best information. Thus, even with the best of intentions, a government standard-setting organization may simply pick what is an objectively poor standard, as almost happened in the case of the United States HDTV standard around 1990 . Only by an accident of timing did the government adopt a digital HDTV standard, rather than an analog standard that would have been immediately obsolete. ${ }^{275}$ Even then, the precise details of the standard remained unresolved as late as $1997 .{ }^{276}$

274. See McGowan \& Lemley, supra note 161, at 336-37.

275. See, e.g., Joseph Farrell \& Carl Shapiro, Standard Setting in High Definition Television, in 1992 Brookings Papers on Econ. Activity 1; Nicholas Negroponte, Being Digital 37-40 (1995).

276. See Joel Brinkley, U.S. and Europe in Battle Over Digital TV, N.Y. TnMEs, Aug. 25, 1997, at D2. 
Second, governmentally set standards may prove durable even when they are demonstrably ill-conceived. ${ }^{277}$ While the market eventually will replace an inefficient standard by "leapfrogging," there is no guarantee that the government will do the same. ${ }^{278}$ And since in our economy the market is the chief determinant of what is in fact efficient, it is not even clear that the government will recognize an inefficient standard in practice. ${ }^{279}$

Third, as has been amply noted in the literature on public choice, government agencies in a position to influence the outcomes of market competition are highly susceptible to "capture" by private entities with an interest in the outcome. 280 Thus, there is no guarantee that a government standard-setting body will act in the public interest, even if it is possible for them to discern what in fact that interest is. ${ }^{281}$ Examples of both of these problems can be found as far back as the eighteenth century, when the British government passed the Longitude Act of 1714 . This Act offered a substantial reward to anyone who could determine precisely how to measure longitude. Two solutions were proposed. Unfortunately, the best technical solution was not the politically popular one. Even more unfortunately, the government standards board took nearly forty years to decide between the competing approaches. ${ }^{282}$

277. This arguably has happened in the HDTV context, where the standard (set five years ago) has not proven to be the best technology in the new computer-driven market. See Caruso, supra note 272 , at C5.

278. Libicki studied government efforts to support seven sets of standards, and concluded that the govemment's efforts were generally unsuccessful, in part because "government is ponderous; it gets under way slowly and once a course is set plods on, well after everyone else may have taken a different path." Martin C. Libicki, Standards: The Rough Road to the Common Byte, in STANDARDS POLICY FOR INFORMATION INFRASTRUCTURE, supra note 152, at 35, 75.

279. Ilene Knable Gotts and Alan Rutenberg make a related point-that a government-mandated compatibility standard may reduce the imcentives for mnovation in the design of interfaces. See Ilene Knable Gotts \& Alan D. Rutenberg, Navigating the Global Information Superhighway: A Bumpy Road Lies Ahead, 8 HaRV. J.L. \& TECH. 275, 320 (1995).

280. See generally Gabriel Kolko, Railroads AND Regulation (1965); Theodore J. Lowi, The End of Liberalism (1969); Robert C. Fellmeth, The Interstate Commission OMISSION: The PUBLIC INTEREST AND THE ICC (1970). Altematively, even a govemment that is not acting at the behest of any private group may also hold its standard hostage to extraneous policy concerns. The government's repeated efforts to force the use of key-escrow cryptography, for example, have resulted in its refusal to allow the industry to converge on an efficient international standard for encryption. On this issue, see, for example, A. Michael Froomkin, The Metaphor Is the Key: Cryptography, the Clipper Chip, and the Constitution, 143 U. PA. L. Rev. 709, 788-89 (I995) and Brock N. Meeks, Still Sucks: Clipper III, WIRED, Aug. 1996, at 37.

281. Cf. McGowan \& Lemley, supra note 161, at 315-22 (making an analogous argument with respect to government restrictions on trade). Once again, the argument can be made that the HDTV standard illustrates this problem. Even the current head of the F.C.C., which set the standard, appears to view it as "a creation of the broadcasting industry" desigued to promote their interests. Caruso, supra note 272 , at $\mathbf{C 5}$.

282. For an entertaining discussion of these events, sce DAva Sobel, Longitude: The True Story of a Lone Genius Who Solved the Greatest Scientific Problem of His Time (1995). 
Finally, soineone must decide which government sets the standard. Since we lack an effective meta-governinent, every government will have to consider for itself whether it should be in the business of setting a particular standard. This raises a number of potential problems. A large national government might wrongly impose uniform regulation on a variety of sectors, only part of which exhibit network effects. Alternatively, a smaller government might regulate only part of a network that is broader than its territorial reach. ${ }^{283}$ Worse, different governments (or even different agencies within the same governinent) might set inconsistent standards, driving a networks market away from uniformity rather than toward it. The traffic example starkly presents the question of choice of government. Because there are learning costs associated with switching driving lanes, the optinal solution would be to have a uniform world rnle regarding lane choice. Unfortunately, different governments have locked in different mles (left side in England, right side in the United States), and changing either rule would impose a significant cost. ${ }^{284}$

We should also be concerned about governmentally set standards where the need for uniformity is not completely clear. As we have seen, it is easy to confuse network-driven markets for inarkets that merely exhibit certain economies of scale. In nany industries, network effects may be sufficient only to drive a part of the market toward standardization. In those circumstances, it would be unwise to compel uniformity. ${ }^{285}$ This concern is really a combination of two potential problems: that the government will think a standard is necessary when it is not; and that it will expand the standard too far in product space (rather than geographic space), forcing consumers who would otherwise have been better off buying a separate product to buy the standard product or nothing.

We should distinguish government standard-setting from another, more innocuous, form of government activity. The government may also act from time to time as a narket participant in a way that affects standards. This may be either an inadvertent or deliberate effort to use

283. This appears to be behind the mass of overlapping and often inconsistent state regulations of the Internet that have begun to appear.

284. For example, the Russian govemment in the Czarist days deliberately built its railroad gauges at a different width than the prevailing European gauge, allegedly to make invasion from Europe more difficult. The difference in gauges persisted for a considerable period of time. See generally Less Car Load Lots Co. v. Pennsylvania R.R. Co., 10 F. Supp. 642, 647 (S.D.N.Y. 1935) (alluding to the different gauges then in force).

285. See Richard Nelson, in Farrell \& Shapiro, supra note 275, at 78-79 (expressing concern that a government-set HDTV standard would end up displacing existing television standards unnecessarily). 
purchasing power to back a single standard. ${ }^{286}$ The government will affect standard choice by its purchasing decisions, whether it wants to or not. Any large purchaser of, say, Microsoft's operating system will help reinforce the network effects in that system. But even where the government acts deliberately to support (or undermine) a standard, such action does not raise the same sorts of concerns as mandatory standards, at least where the government lacks monopsony power. The market can and will ignore government efforts at leadership if its interests lie elsewhere. Consider the case of the metric system in the United States. The government sought for a short period in the 1970s to promote national acceptance of the metric system of measurement, the system uniformly used in the rest of the world. Government efforts at education and at "priming" the transition by switching government signs and publications to metric failed to tip the market, however. The government soon abandoned these efforts, and has remained a public force in favor of the English system by publishing information (such as speed limit and mileage signs) using only that system. ${ }^{287}$ Ironically, at about the time the government ended its public support of the metric system for general use, the tool and automotive industries switched en masse to the metric system, apparently driven by the growing internationalization of competition in their industries. The government is unquestionably a player in setting this standard, but it is equally clear that at least its voice alone is not determinative, and that in fact, the naturally developing standard will vary from time to time and from industry to industry, depending on the dynamics of each.

286. See Howard S. Dakoff, Note, The Clipper Chip Proposal: Deciphering the Unfounded Fears That Are Wrongfully Derailing Its Implementation, 29 J. MARSHall L. REv. 475, 482-84 (1996) (identifying one case where the government has done so).

287. The federal government has not ended its support for the metric system; it has simply chosen alternatives to exhortation. As late as May 1994, in report entitled A Metric for Success, the Commerce Department pondered the question of "how long the United States can hold out against the worldwide use of the International System of Units (SI), the modem metric system." Gary P. Carver, A Metric for Success (visited Apr. 3, 1998) <http:/ts.mist.gov/ts/htdocs/200/202/5425.html>. The report confirms that " $[\mathrm{m}]$ anufacturers of cars, tractors, and earth-moving equipment, including their suppliers switched to the metric system in the 1970s and 1980s." Id. The report goes on to recount as Congressional policy "that the metric system is the preferred system of weights and measures for trade and commerce." Id. The report further recounts "Metric Highlights in U.S. History," including the agreement of Thomas Jefferson and John Quincy Adams on the desirability of international base10 standardization. Id. For a department-by-department account of federal metrication strategies, see National Institute of Standards and Technology, Federal Metric Progress in 1993 (visited Apr. 3, 1998) <http://ts.nist.gov/ts/htdocs/200/202/5413.html>. 


\section{Telephony}

"How can an Act that says 'shall' 2,036 times be deregulatory?"

Joseph Farrel1288

Network effects arguments have had no trouble taking root in the telephone industry. ${ }^{289}$ Indeed, telephony is itself the paradigmatic example of a "pure" network, about which even skeptics like Liebowitz and Margolis concede that the network effects story has some validity. ${ }^{290}$ The very point of the telephone network is to connect one person to other people. It is no surprise, therefore, that the efficient number of telephone networks worldwide is one. We are all better off connected to the same phone network than we would be connected to different phone networks. ${ }^{291}$ One can conceive of this either as a cost advantage (denser phone networks have lower per-unit costs than sparse ones, and the greater one's share of a market, the more dense one's network will be relative to competitors) or as a bandwagon network effect (everyone wants to be connected to the network to which everyone else is connected). In fact, it is both.

While network theory holds that existing members of the telephone network will enjoy some benefit from the addition of new telephone users to the network, however, it does not follow that this marginal private benefit exceeds or equals the marginal private cost of adding new members. Nor does it mean that the private marginal costs and benefits will equal the costs and benefits to society at large, even assuming, as telephony policy has decreed, that society benefits as the extent of the telephone network approaches the goal of universal service.

Absent any market imperfections, the firms coinprising the telephone network might serve collectively to solve the coordination problem among existing users, charging them an amount derived to equate private marginal benefits and costs of the scope of the network. Such a network would be optimal with respect to private benefits. The policy choices animating telephony, however, have sought to extend the scope of the network farther, to the point at which, in strictly economic terms, the marginal social cost of adding users may well exceed marginal social benefits. This fact also provides a useful example of the difference

288. Joseph Farrell, Creating Local Competition, 49 FED. CoMm. L.J. 201, 211 (1996) (referring to the Telecommunications Deregulation Act of 1996).

289. See generally Glen O. Robinson, The "New" Communications Act: A Second Opinion, 29

CoNN. L. REv. 289, 323-24 (1996) (articulating the standard network effects explanation).

290. See Liebowitz \& Margolis, Uncommon Tragedy, supra note 5, at 139-40.

291. See, e.g., Farrell, supra note 288, at 203. 
between economies of scale and network effects. The logic of the ratio of inherent to network value may imply positive returns at some level to each additional adopter of the telephone network. Network theory does not suggest, however, that such returns will necessarily be sufficient to justify the cost of facilitating such adoption. ${ }^{292}$

Regulators were quick to recognize the cost advantage of market share in telephone networks. This advantage corresponded to a wellknown, if rare, economic beast known as the natural monopoly. A natural monopoly is simply a market in which average total cost declines over the entire range of relevant market demand, such that it is most efficient for one producer to serve the entire market. ${ }^{293}$ See Figure 1:

292. Thus, one should distinguish between arguments for so-called universal service by subsidizing local telephone rates and arguments for including everyone who would buy a phone in an unregulated market within the same network. As Farrell notes, universal service is not a necessary consequence of network effects. See id. at 212-13; see also Robinson, supra note 289, at 324-25 (making the important point that network benefits decline at the margins, so that it an empirical question whether adding every last person to the network via subsidy is of net social benefit). We do not, after all, have a "universal service" requirement for software operating systems, under which everyone in the country is entitled to buy Microsoft Windows at less than cost. See id. at 323.

293. See, e.g., PIERCE, supra note 13, at 12-15. 
[Vol. 86:479

Figure 1

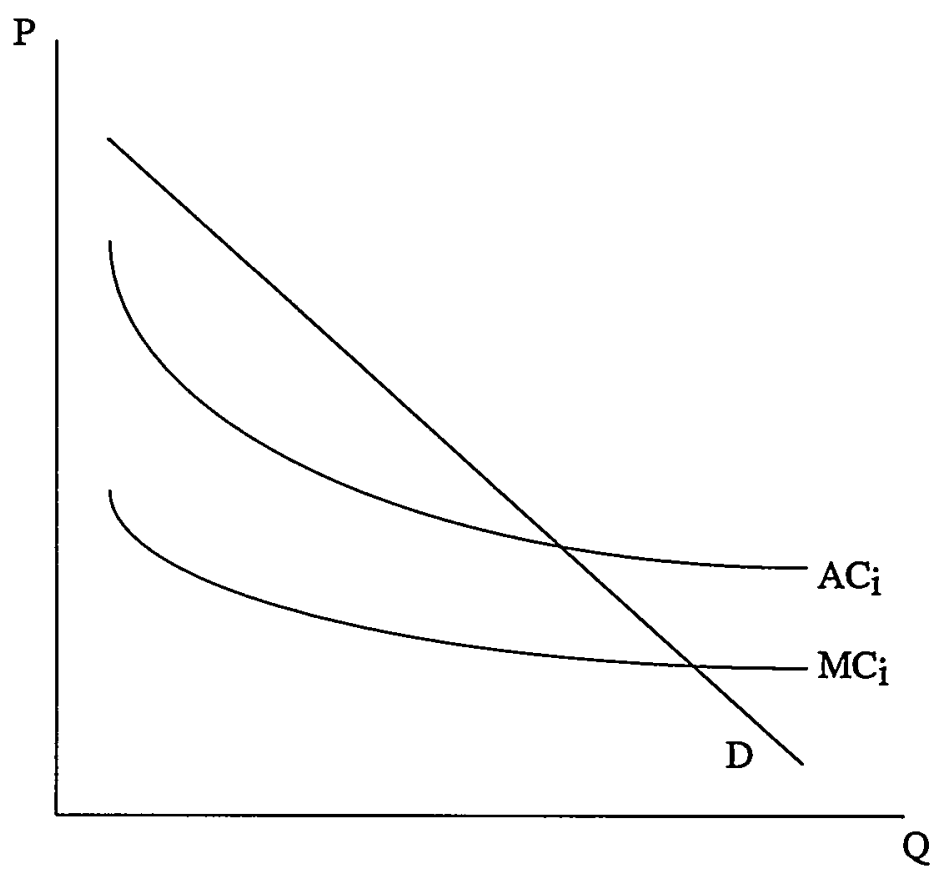

$D$ reflects market demand, $M C_{i}$ is the marginal cost of a single firm in the industry, and $A C_{i}$ is the average cost of the firm. 
To the extent that anyone thought about network effects back then, such effects seemed to bolster the natural monopoly story, because network effects predicted that a single telephone network would emerge from the competition between different networks at the turn of the century. Indeed, one network did emerge victorious from this standards competition-Bell's. At the time, the accepted thing to do when one encountered a natural monopoly was to regulate it, because competition was presumed unable to provide long-run benefits in such a market, and because without some form of regulation, the monopolist would charge a supracompetitive price. ${ }^{294}$ If done right, regulation would, in theory, set the minimum efficient price necessary for the monopolist to recover its operating costs and a reasonable return on its capital investment. ${ }^{295}$ Of course, one of the major lessons of economics in the last fifty years is that regulation is almost never done right, for a variety of reasons: imperfect information, industry "capture" of regulators, and so on..$^{296}$

In hindsight, it should perhaps have been obvious that network effects did not dictate a telephone network run by a single firm as a regulated natural monopoly. Rather, as in the intellectual property and antitrust cases we have considered so far, network effects merely dictated that one network was the efficient outcome. How many different firms participated in that one network was purely a question of interoperability-competition could perhaps have been regulated rather than excluded entirely. ${ }^{297}$ Nonetheless, for most of this century, the Federal Communications Commission took its mandate to be the exclusion of competition from the telephone market, and the regulation of AT\&T as a monopoly provider of telephone services and equipment. ${ }^{298}$ Beginning

294. See id. at 14; Paul A. Samuelson \& William D. Nordhaus, Economics 911 (12th ed. 1985) (discussing the economics of natural monopoly).

295. The historic revenuc requirement for regulated monopoly firms is $R=O+(K-d)(r)$, where the revenue requirement $R$ is set at the operating expenses including depreciation of capital equipment $(O)$ plus a rate of return $(r)$ on the current rate base (capital investment $(K)$ less depreciation (d)). See, e.g., Pierce, supra note 13, at 51; Sidney Shapiro \& Joseph P. Tomain, Regulatory LAW AND POLICY 198 (1993). There is significant dispute on how that price should be set in the telecommunications industry. For one view, see J. Gregory Sidak \& Daniel F. Spulber, The Tragedy of the Telecommons: Government Pricing of Unbundled Network Elements under the Telecommunications Act of 1996, 97 Colum. L. REv. 1081 (1997).

296. See generally PIERCE, supra note 13, at 173-211.

297. For an account of the regulatory cycles of American telecommunications, sec Jim Chen, The Legal Process and Political Economy of Telecommunications Reform, 97 ColuM. L. REV. 835 (1997). Indeed, some have argued that competition was a greater spur to network growth than a standard owned by a single company. See Richard Gabel, The Early Competitive Era in Telephone Communication: 1893-1920, 34 LAW \& CoNTEMP. ProBs. 340, 344-45 (1969); Robinson, supra note 289 , at 322 . On the other hand, if interconnection was technically more difficult in the past, that might have made the regulatory approach problematic.

298. See In re Policy and Rule Concerning Rates for Dominant Carriers, 4 F.C.C.R. 2873, 288288 (1989) (reviewing this history); see also Farrell, supra note 288, at 204-06. 
in the late 1960 s with the Carterfone decision, ${ }^{299}$ the FCC grudgingly began to allow competition into first the equipment and then the longdistance segments of the market. Competition in those areas-and the principle of nondiscriminatory interconnection-were cemented in the consent decree breaking up AT\&T. ${ }^{300}$ Once the single phone network was divided imto seven "regional Bell operating companies" (plus some independents) in charge of local phone service, and a potentially unlimited number of long-distance carriers, it was evident to all that interconnection was at the heart of the phone system.

The problem then became how to ensure effective interconnection. In part, this is a technical and accounting problem-what standards should be set to ensure that different companies' phone systems work together, and who should foot the bill. ${ }^{301}$ But it is also an antitrust problem involving incentives to discriminate. The Antitrust Division took the position in $A T \& T$ that it could not prevent discrimination in interconnection unless the local telephone monopolists were "walled off" from the competitive long-distance sector. ${ }^{302}$ This solution is rather drastic from an antitrust perspective-few seriously suggest that we break up Microsoft, for example (or any other vertically integrated company, for that matter).

More recently, Congress tried a different approach. In the 1996 Telecominunications Reform Act, ${ }^{303}$ Congress agreed to break down the wall separating local from long-distance providers on the condition that the local telephone market itself be opened to competition. The theory is that local telephone providers cannot effectively discriminate in favor of a particular long-distance company if local telephone competition constrams them..$^{304}$ This may or may not be true; it remains to be seen whether individual consumers will switch their local service provider to

299. See In re Use of the Carterfone Device in Message Toll Telephone Service, 13 F.C.C.2d 420 (1968); see also Hush-A-Phone Corp. v. FCC, 238 F.2d 266, 269 (D.C. Cir. 1956) (allowing attachment of non-AT\&T equipment which did not affect the phone or the network).

300. See United States v. AT\&T, 552 F. Supp. 131, 227 (D.D.C. 1982), aff'd sub nom. Maryland v. United States, 460 U.S. 1001 (1983).

301. The much-celebrated convergence of various communications media, including conventional telephony, wireless telephony, and coaxial cable, complicates the technical problem, because each should ideally interconnect to the other. So, too, does the rise of Intemet telephony, which presents a rather different set of interconnection issues. See European Telecom Standards Body to Work on Standard for Internet Telephony, 2 ELEC. INFo. PoL. \& L. RPT. 520, 520 (May 16, 1997); Dennis W. Moore, Jr., Comment, Regulation of the Internet and Internet Telephony through the Imposition of Access Charges, 76 TEx. L. REv. I83 (1997); Robert Cannon, The Internet at the FCC: Cybernauts ys. Ma Bell, (visited June I1, I997) <http://www.cais.net/cannon/>.

302. See Roger G. Noll \& Bruce M. Owen, The Anticompetitive Uses of Regulation: United States v. AT\&T, in The ANTITRUst Revolution 290 (John E. Kwoka, Jr. \& Lawrence J. White eds., 1989). Farrell refers to this approach as "quarantining the monopoly lest it infect the competitive segments." Farrell, supra note 288, at 207.

303. Pub. L. No. 104-104, 110 Stat. 56 (1996).

304. See Farrell, supra note 288, at 207-08. 
avoid long-distance discrimination, at least where the discrimination does not impose major costs on them. In any event, it seems likely that whether or not the local market is opened to competition, the FCC will continue to impose mandatory imterconnection requirements on all the relevant players. ${ }^{305}$

Network effects arguments are virtually irrefutable in telephony. As history demonstrates, however, accepting that fact does not dictate the course the industry must take. The current course-opening the network to competition by compelling comparably efficient interconnection between all players-seems a logical one, given what we know of network effects. ${ }^{306}$ But requiring interconnection may force the government to remain a player in this market for the foreseeable future, because at least some market players may have an incentive not to interconnect with all comers on nondiscriminatory terms. As Farrell contends, therefore, "for true sharing of network externalities, and for true sharing of economies of density, some intervention in the bargaining process is likely needed."307

\section{E. Internet Governance}

The Internet, like the telephone network, exhibits a strong form of network effect-the network is the product in a very real sense. ${ }^{308}$ Given our experience with the telephone network, and the parallels between the two, one might expect the Internet to exhibit the same market structure. But it doesn't. The Internet looks nothing like the old Bell System, with a single regulated corporation in charge of all the connections. In fact, it doesn't even look like the new, streamlined model of telephone competition, in which various large network owners will be forced to interconnect on governmentally set (and enforced) terins. Rather, the Internet appears, at least at first glance, to be an example of working anarchy-it consists of millions of different entities around the globe, public and private, which connect together in a patchwork network of uncertain provenance.

How can this be? The answer is twofold. First, the Internet is not composed entirely of its own set of lines connecting one Internet user to

305. See 47 U.S.C. $\$ 255-56$ (1996) (imposing interconnection obligation pursuant to regulations set by the FCC). It has also continued to restrict the power of the RBOCs to enter other markets pending the development of genuine competition. See Leslie Cauley, Genuine Competition in Local Phone Service Is a Long Way Off, WaLl ST. J., Dec. 15, 1997, at A1; Leshe Cauley, Baby Bells Remain Bystanders in Phone Takeover Wars, WALL ST. J., Oct. 16, 1997, at B4.

306. See supra notes $150-160$ and accompanying text (discussing interoperability as a solution to monopoly power created by network effects).

307. Farrell, supra note 288, at 211 (suggesting possible government regulations to ensnre interconnection at efficient prices).

308. See Lemley, Internet Standardization, supra note 46, at 1044-45. 
the next, though some Internet-specific "backbone" wires do exist. ${ }^{309}$ Rather, the Internet piggybacks on existing communications technology, notably the wire telephone network, using available space to send distributed packets of imformation from place to place. ${ }^{310}$ As a result, no one can fairly be said to have "built" the Internet in the physical sense, though, of course, a number of people built early pieces of it, and United States government agencies such as the National Science Foundation and the Defense Advanced Research Projects Agency contributed parts of the network backbone. ${ }^{311}$

Second, and more important, the Internet itself is nothing more than a relatively simple set of computer protocols (commonly called TCP/IP today) governing the interchange of data. In other words, what we think of as "the Internet" is really only a published, nonproprietary interface standard. ${ }^{312}$ Anyone who uses the standard to transmit data from her computer is "on" the Internet; anyone who does not use the standard is not.

The success of the Internet is due largely to its spectacular interoperability. It did not drive out its competitors in the "computer networking" market so much as to subsume them. ${ }^{313}$ In the mid-I980s, one could participate in computer networking by joining one of approximately 50,000 bulletim board systems (or BBSs), one of the fledgling on-line service providers like Prodigy or Compuserve, or, depending on where one worked, one of the private networks of military or academic computers. Each of these computer networks was largely incompatible with the others, with the result that joming a bulletm board allowed you to communicate only with other members of that bulletin board. Interconnection protocols, beginning with Usenet and SMTP, allowed messages to be transferred between different groups of networked computers. As the communications technology between networks became more seamless, people began to think of themselves as on the Internet itself, rather than connected to a private computer networking group which could itself exchange data with other private groups. From the perspective of network economic effects, the Internet is a tremen-

309. As Internet traffic increases, these Net-specific providers may become more common. Net-specific bandwidth requires revision in existing pricing models, bowever. See Kevin Werbach, Digital Tornado: The Internet and Telecommunications Policy, in 502 PLI INST. ON Telecommunications Pol'y \& Reg. 387, 446-49 (1997).

310. See generally JoshuA EdDINGS, How THE INTERNET Works (1994).

311. For an entertaining discussion of the early development of the Internet, see KaTIR HAFNER, Where Wizards Stay UP Late (1996). See also Barry M. Leiner et al., A Brief History of the Internet (visited Jan. 7, 1998) <http://www.isoc.org/internet-history/>.

312. See David G. Post, Anarchy, State and the Internet: An Essay on Law-Making in Cyberspace, 1995 J. ONLINE L. art. 3, at TII 12-13; Leiner et al., supra note 311.

313. For a good legal description of the Internet, see ACLU v. Reno, 929 F. Supp. 824, 830-31 (E.D. Pa. 1996), aff'd, 117 S. Ct. 2329 (1997). 
dous success story because it allows different and often incompatible computer systems to communicate with each other, expanding the size of the network without requiring purchase from the standards owner.

Things are not quite as simple as this, however. TCP/IP does not do everything automatically and without supervision, any more than do the stock exchanges, often cited as the most efficient of "unregulated" markets. ${ }^{314}$ Rather, there are a wide variety of rule-making groups that enforce standards on the Internet. For example, technical standards (including updates or changes to the TCP/IP protocol) are set by the Internet Engineering Task Force (IETF), a voluntary body with no "official" authority over the Internet beyond the willingness of Internet users to adopt the changes it proposes. ${ }^{315}$ Further "rules" are created by the code written both into the Internet protocols and into privately owned programs, like Netscape Navigator, Microsoft Internet Explorer, and Sun's Java, that operate on the Internet. ${ }^{316}$

For our purposes, though, the best example of the role of network effects in Internet governance has to do with domain names. InterNIC (and the private company Network Solutions, Inc.) set the rules for Internet addresses, mapping the domain names commonly used to identify individuals and corporations on the Net to the numeric IP addresses that are actually registered to particular servers. ${ }^{317}$ For addressing to work,

314. See R.H. COASE, Essays ON ECONOMICS AND EcONOMISTS 112 (1994) ("[S]tock and produce exchanges are often used by economists as examples of perfect or near-perfect competition. But these exchanges regulate in great detail the activities of traders (and this quite apart from whatever public regulation there may be).").

315. For a discussion of standard-setting in the all-volunteer IETF, see A. MichaEL FroomKIN, A Model of INTERnational Law AND Society 16-22 (Working Paper, 1997), A. Michael Froomkin, The Internet as a Source of Regulatory Arbitrage, in BORDERS IN CYBERSPACE 129 (1997), Lewis C. Lee \& J. ScotT Davidson, INTellectual Property for the INTERNet 180-82 (1997), William Lehr, Compatibility Standards and Interoperability: Lessons from the Internet, in STANDARDS Policy FOR INFORMATION INFRASTRUCTURE, supra note 152, at 131-37, and Paulina Borsook, How Anarchy Works, WIRED, Oct. 1995, at 110. It is interesting, and for our purposes perhaps instructive, that the quasi-official body designing computer and communications standards, the International Standards Organization (ISO), during the 1980s refused to accept TCP/P as a networking standard. Instead, the ISO offered its own standard, called Open Systems Interconnection (OSI). OSI failed to replace the basic TCP/IP standard, which continues to govern the Internet. See Froomxin, MOdel of INTERATIONAL LAW, supra, at 15.

316. An important and growing body of legal scholarship has focused attention on the role of "code" in setting quasi-legal mles on the Net. See, e.g., Lawrence Lessig, The Constitution of Code: Limitations on Choice-Based Critiques of Cyberspace Regulation, 5 COMMLAw Conspectus 181 (1997); Lessig, supra note 202; Lawrence Lessig, Reading the Constitution in Cyberspace, 45 EMORY LJ. 869 (1996) [hereinafter Lessig, Constitution in Cyberspace]; DAvid G. Post, Bargaining in the Shadow of the Code: File Caching, Copyright, and Contracts Evolving in Cyberspace (Working Paper 1997); Reidenberg, supra note 181. For a concrete example of "code-based regulation," see the Digital Telephony Act of 1994, Pub. L. No. 103-414, 108 Stat. 4279, and Susan Freiwald, Uncertain Privacy: Communication Attributes after the Digital Telephony Act, 69 S. CAL. L. REv. 949 (1996).

317. The interaction between InterNIC's "first-come, first-serve" rule for allocating Internet domain names and trademark law has been explored elsewhere. See, e.g., Dan L. Burk, Trademarks 
someone must maintain a list of valid IP addresses and their aliases. Further, everyone on the Internet must work from that list, so that a user who types in "www.ibm.com" will find the computer identified with that alias. Network Solutions (NSI) has performed this function for several years now with respect to certain of the international top-level domains, or iTLDs, like ".com". ${ }^{318}$ The list of names and matching IP addresses are entered into a series of "root doinain name servers" or DNSs that are $\mathrm{rnn}$ by volunteers. ${ }^{319}$ The servers are themselves updated regularly. If your name is on the list, you can be found on the Internet. If not, anyone who types that name into their browser or mail program will not be able to reach you. ${ }^{320}$

Obviously, the DNS servers are central to the functioning of the Internet. And if you want your name to have a DNS entry, the only obvious way to get it is to request that NSI or one of the national registrars with which it works put it there. ${ }^{321}$ But NSI is a private entity; it is not at all clear what authority it has to "run" the Internet, or indeed who might be able to give it that authority. NSI took over operation of the domain name registration system based on a contract from the U.S.

Along the Infobahn: A First Look at the Emerging Law of Cybermarks, 1 RicH. J.L. \& TEch. 1 (1995); Gary W. Hamilton, Trademarks on the Internet: Confusion, Collusion, or Dilution?, 4 TEX. INTELL. Prop. LJ. 1 (1995); David J. Loundy, A Primer on Trademark Law and Internet Addresses, $15 \mathrm{~J}$ MARShALl J. COMPUTER \& INFo. L. 465 (1997); James W. Marcovitz, ronald@mcdonalds.com"Owning a Bitchin'" Corporate Trademark as an Intermet Address-Infringement?, 17 CARDozo L. Rev. 85 (1995); Carl Oppedahl, Remedies in Domain Name Lawsuits: How is a Domain Name Like a Cow?, 15 J. Marshall J. Computer \& INFo. L. 437 (1997); Ira S. Nathenson, Comment, Showdown at the Domain Name Corral: Property Rights and Personal Jurisdiction over Squatters, Poachers and Other Parasites, 58 U. PrTT. L. REv. 9 I1 (1997); see also Jonathan Agmon, et al., Domain Names and Trademarks-What's in a Name? (last modified May 8, 1996) <http://www.ll.georgetown.edu/lc/ internic/domain1.html (cataloguing information about domain name trademark disputes). On an effort to challenge InterNIC's mles, see Roderick Simpson, Dueling Domains, WiRED, Aug. 1996, at 64.

318. There are also national TLDs for eaeh country, ending with the two-letter code for that country. Administration of these national TLDs is generally in the hands of entities within each country, though of course national TLDs must also be included in the root DNS if they are to be accessible to people elsewhere on the Internet. It is NSI which coordinates the inelusion of the relevant lists.

319. See Rebecca Quick, Is the Internet Outgrowing Its Volunteer Traffic Cops? WALL ST. J., Sept. 12, 1997, at B6.

320. The recent corruption of data in root DNS servers graphically illustrated this problem, bringing down most Internet addressing for several hours in July of 1997. See John Markoff, Ignored Warning Leads to Chaos on the Internet, N.Y. TIMES, July 18, 1997, at A1; David Post, Breaking Up the Domain Name Monopoly, ReCORDER, Sept. 25, 1997, at 4.

321. "If you want to attach your network to the Internet, but you don't like NSI's policies, for whatever reason, you quickly leam that NSI is the only game in town." Copyright Protection on the Internet: Hearings Before the Subcommittee on Courts and Intellectual Property of the House Committee on the Judiciary on H.R. 244I, 104th Cong., 2d Sess. (1996) (statement of Catherine Simmons-Gill on behalf of the International Trademark Association). In Larry Lessig's parlance, this is more of a "code" restriction than a policy matter. If the root DNS name servers are not configured to "recoguize" a TLD (like ".web"), they simply will not match it with an IP address, and messages to that domain will not be delivered. Period. 
National Science Foundation. That contract will expire in 1998, and NSF has already indicated that it will not renew the contract. ${ }^{322}$

So what happens to the database of names at the heart of the DNS system? Consider several possible outcomes. First, NSI may decide to keep administering the DNS system, and the courts may decide it has a right to control the database of names. If this occurs, control over the network will effectively have been placed in the hands of a single, private entity, which will become the de facto standard-setter. In theory, NSI could be displaced from this position by market competitionsomeone else could set up a coinpeting, incompatible domain name server, and, if enough users of the Internet (and therefore of the NSI DNS system) switched to this incompatible systen, the owners of the new server would become the new market leader. In practice, network effects make this outcome unlikely, because a "competing Internet" that few people are using will not be attractive to those already on the current Internet. ${ }^{323}$ Indeed, some halting efforts toward such an alternate DNS system have so far been unsuccessful. ${ }^{324}$ While NSI's control over DNS might also be displaced by hacking, ${ }^{325}$ any such unauthorized access to the DNS servers is likely to be illegal. ${ }^{326}$

A second possibility is that NSI will get to keep its control over the DNS database, but that some legal constraint will be imposed on its

322. See David S. Hilzenrath, Network Solutions Dropped as Registrar of Internet Domains, Wash. POSt, April 24, 1997, at E1; NSF Won't Renew Network Solutions' Contract, SEARCHER, June 1997 , at 40 .

323. Unlikely is not impossible, however. There are some reasons to believe that even here, network effects inight not prevent effective competition between standards. First, the switch to a new domain name system need not be a complex one. NSI cannot claim to own the basic protocols that govern the Internet. It might be relatively straightforward, therefore, for a concerted group of large Internet users to switch their allegiance in a public way, causing others to follow suit. Seeond, and more important, it might be possible to run a new DNS system alongside the existing one, so that a company could be on both systems at once. If this is feasible, IBM could be accessed through ibm.com via NSI, and through a different (or conceivably even the same) domain name on a different system. Which system a user used would depend on how she accessed the Net. Lock-in concerns are significantly alleviated to the extent that users can simultaneously use more than one standard, as we have seen. See supra notes $135-149$ and accompanying text.

324. For example, both Alternic and a DNS altemative called eDNS exist, but neither routes a significant amount of traffic because most people do not have their routers configured to take instruction from these "altemative" DNS servers. For more on these alternatives, see Neal J. Friedinan \& Kevin Siebert, The Name Is Not Always the Same, 20 SEATtLE U. L. Rev. 631, 657-61 (1997).

325. Such a hack would involve spoofing NSl's identity to convince the DNS server to accept updated information provided by an unauthorized third party. For a technical discussion of the possibility of DNS entry hacking, see Secure Networks Inc., BIND Vulnerabilities and Solutions, Security Advisory April 22, 1997 (visited. July 1, 1997) <ftp://ftp.secnet.com/advisories/SNI12.BIND.advisory>. Such a BIND hack was perpetrated in July by Alternic, a company challenging NSI's exclusive authority over TLDs. Alternic may now face criminal prosecution for its actions. See Todd Wallack, Net Domain Name Squabble Takes Unexpected Route, NeTwork WorLd, July 28, 1997 , at 10.

326. See, e.g., 18 U.S.C. § 1030 (prohibiting unauthorized access to network computers). 
discretion in running the DNS system. Soine such constraints are obvious-for example, the strong weight of authority holds that NSI's domain name registration policy must yield to the contrary dictates of trademark law. ${ }^{327}$ But there have also been hints of a more fundamental governmental role in compelling access to NSI's domain name servers. Indeed, litigation on this issue has already begun. In a complaint filed in March 1997 against NSI, a company called PGP Media alleged that NSI's failure to incorporate PGP-registered domains violated the antitrust laws. ${ }^{328}$ The claim is that NSI's configuration file "is the central (and essential) technical bottle-neck facility for the Domain Name Registration Market,"329 and the plamtiffs seek "extremely limited and narrowly tailored injunctive relief to compel NSI to add reference in the Configuration File on the NSI Root Nameservers ... so that PGP may compete with NSI in the Domain Name Registration Market for Domain Name registrations ...."330 There are a number of potential problems with such a claim, including a possible antitrust immunity defense based on state action ${ }^{331}$ and the general reluctance of courts to declare privately held facilities to be essential. ${ }^{332}$ But the fact that the claim was

327. See, e,g., Comp Examiner Agency v. Juris, Inc., 1996 WL 376600 (C.D. Cal. Apr. 25, 1996) (injunction vs. direct competitor); Actmedia, Inc. v. Active Media Int'1, 1996 WL 466527 (N.D. 111. July 17, 1996) (same); Cardservice 1nt'1 v. McGee, 950 F. Supp. 737 (E.D. Va. 1997) (same); Planned Parenthood Federation v. Bucci, 42 USPQ2d 1430 (S.D.N.Y. 1997) (anti-abortion activist can't use Planned Parenthood name); Intermatic v. Toeppen, 947 F. Supp. 1227 (ND 111. 1996) (Toeppen's interactive map enjoined as dilution, but not as trademark infringement; reselling domain name is "commercial use"); Panavision Int'l v. Toeppen, 945 F. Supp. 1296 (C.D. Cal. 1996) (same dilution analysis); Hasbro, Inc. v. Internet Entertainment Group, 40 USPQ2d 1479 (W.D. Wash. 1996) (adult site dilutes famous name for children's game); Toys'R'Us v. Akkaoui, 40 USPQ2d 1836 (N.D. Cal. 1996) (dilution of family of "R' Us" marks by defendant's "adultsrus" domain name); Inset Systems v. Instruction Set, Inc., 937 F. Supp. 161 (D. Conn. 1996) (dictum stating that use of a trademark as a domain name may cause confusion in the marketplace). But see Giacalone $v$. Network Solutions, 1996 WL 887734 (N.D. Cal. June 14, 1996) (injunction against NS1 placing a registered domain name on hold at the request of a trademark owner). Cf. DEC v. Altavista Technology, 960 F. Supp. 456 (D. Mass. 1997) (injunction vs. ATI's use of "altavista" for services, even though it was licensed by DEC to use altavista.com). The weight of present authority thus supports the desirable conclusion that it is trademark law, not NSI's "first-come, first-serve" registration policy, that will determine who owns a domain name where the two policies are in conflict.

328. See PGP Media, Inc. v. Network Solutions, Inc., No. 97 Civ. 1946 (RPP) (S.D.N.Y. filed March 20, 1997), available at (visited March 24, 1997) <http://www.jmls.edu/cyber/cases/pgpmc.html>; see generally Alexander Gigante, Blackhole in Cyberspace: The Legal Void in the Internet, 15 J. Marshall J. Computer \& INFo. L. 413, 430 (1997) (suggesting that NS1 as a private actor might be subject to antitrust liability).

329. PGP Media, No. 97 Civ. 1946 at 1.

330. Id.

331. For a detailed discussion of the state action doctrine, see McGowan \& Lemley, supra note 161 , at $315-60$. PGP Media did anticipate this defense, specifically alleging that NS1 is no longer effectively supervised by NSF. PGP Media, No. 97 Civ. 1946. Once the NSF-NSI contract expires, of course, this claim will be even stronger.

332. See supra notes $119-120$ and sources cited therein (discussing the essential facilities doctrine). 
filed at all pays tribute to the growing confusion over precisely who should have authority to "issue" domain names. ${ }^{333}$ While NSI might claim to own intellectual property rights in its database of DNS entries, such a claim is dubious under current law. ${ }^{334}$

Finally, the governmeut could decide to remove NSI's control over domain name registration entirely, replacing it with either a de novo open system of private registration or even a system of government registration. In February 1997, the International Ad Hoc Committee (IAHC), a nongovernmental Internet advisory group set up to study the issue, recommended the creation of seven new "generic top-level domains (gTLDs)" to be administered on a global basis by "multiple competing registrars" overseen by a (private) Council of Registrars and a (private) DNS Policy Oversight Committee. ${ }^{335}$ The international nature of this approach is an important indication that one canuot merely say "the government" will establish a new policy. While the IAHC report was prepared under the informal auspices of the World Intellectual Property Organization, and the "Memorandum of Understanding" it established ${ }^{336}$ is deposited with the International Telecommunications Union, no governmental or international legal authority stands behind the proposal, a fact which has upset both the United States and the European Union. ${ }^{337}$ Indeed, the Memorandum of Understanding declares that it is agreed to by "The Internet Community," ${ }^{3338}$ an ethereal entity if ever there was one. NSI probably has no enforceable legal obligation to comply with a dictate from such a body, though of course the MoU might well end up being incorporated into national or international law. ${ }^{339}$ Alternatively, whatever private group claims authority over

333. Private suits are not the only means of raising antitrust claims. In July of 1997, NSI disclosed in an SEC filing that the Antitrust Division of the Department of Justice was investigating whether NSI had violated the antitrust laws in its administration of the domain name registration system. See Jennifer B. Lucas, Domain Name Practices Are Subject of DOJ Antitrust Investigation, EuEC. INFo. PoL. \& L. RPT., July 18, 1997, at 748-49.

334. NSI has apparently agreed to allow access to its database, but not to its software for operating the database. See Kelly Flaherty, NSI Focus on Internet Talks in Congress, RecoRder, Oct. 2,1997 , at 1,4 .

335. See Final Report of the International Ad Hoc Committee: Recommendations for Administration and Management of gTLDs, (visited June 19, 1997) <http://www.iahc.org/draft-iahcrecommend-00.html>. The IAHC report declares that iTLDs are within its "purview," but cites no authority.

336. Establishment of a Memorandum of Understanding on the Generic Top Level Domain Name Space of the Internet Domain Name System (gTLD-MoU), (visited Dec. 11, 1997) <http://www.iahc.org/gTLD-MoU.html>.

337. See David Loundy, E-Law: International Intrigue Meets Internet Domain Name System, Cyberspace Lawyer, June 1997, at 14-16.

338. See supra note 336

339. For a discussion of this problem, and proposals for national or international legislation along these lines, see Gigante, supra note 328, at 426-29. See also David W. Maher, Trademark Law on the 
Internet domain names is undoubtedly subject to existing national laws, at least if the country applying those laws has jurisdiction. ${ }^{340}$

The Climton Administration has recently proposed an alternative to the Memorandum of Understanding. ${ }^{341}$ The Administration's proposal would create some new top-level domains and would also allow for competition im the issuance of domain names. But, unlike the Memorandum, it contemplates at least a temporary role for the U.S. government in overseeing the operation of the competitive domain-name registration market, to be replaced eventually by a nonprofit organization. ${ }^{342}$

From an economic perspective, there is probably inore social value in a shared, than in a monopolistic, top-level domain system. Internet domain names are valuable commodities; one generic domain name was recently sold for over $\$ 100,000 .^{343}$ NSI currently charges only $\$ 100$ per year per domain name, up from $\$ 0$ a few years ago. But an NSI freed of governmental constraints on its pricing policy probably has significant power to raise the price of domam names, either across the board or by price discrimination. Competition among domain name registrars would constrain such power, particularly if (as the IAHC report recommends) competing registrars could register names within a single TLD. If IBM can choose to obtain rights to "ibm.com" from either NSI or from a competitor such as PGP, it will be able to shop effectively for the lowest registration price, and price should approach marginal cost. ${ }^{344}$

On the other hand, administering such a competitive system will be more difficult than running the current system. Someone must control

Internet-Will it Scale? The Challenge to Develop International Trademark Law, 16 J. MARSHALL J. COMPUTER \& INFO. L. 1, 5 (1997) ("The answer to the question of 'who's in charge?' is 'no one."').

340. For a discussion of jurisdiction on the Intemet, see Dan L. Burk, Jurisdiction in $a$ World without Borders, 1 VA. J.L. \& TECH. 3 (1997) (visited August 4, 1997) <http:// www.student.virginia.edu/ vjoIt/voI1/ BURK.htm>. It is worth noting that the current administrators of global TLDs have followed a de facto policy of granting control over "country" domains-the two. Ietter codes in widespread use outside the United States-to the government of the relevant country, and not necessarily to the original delegate. See Internet Governance Not Scaling Well, Cook REPORT, September 1997 (6.6), (visited Jan. 7, 1998) <http://www.cookreport.com/06.06.shtml>.

341. See Amy Harmon, U.S. Plan on Internet Names Lacks Support from All Users, N.Y. TIMES, Feb. 2, 1998, at C1.

342. See Rory J. O'Connor \& Larry Williams, Group to Manage Internet Proposed, AustiN Am.-Statesman, Jan. 31, 1998, at D1.

343.. See Laurie J. Flynn, Prototype Internet Name is Sold for \$100,000-Plus, N.Y. TImes, May 12, 1997, at C4 ("intemet.com" domain name worth over $\$ 100,000$ ); Rory J. Thompson, Business Deal, INFORMATION WEEK, June 9, 1997, at 12 ("business.com" sold for record sum).

344.. By contrast, a competing top-level domain which cannot register ".com" domains might find itself handicapped by the convenience effect of the widesprcad use of the .com TLD. IBM may be less likely to switch to a competing domain name registrant if the TLD they use is an unfamiliar one, since part of the value of having a nane like "ibin.com" is that those who want to visit the site for the first time can easily guess the name. 
access to the DNS root servers; either one of the registrars must be trusted to give nondiscriminatory access to the servers, or some governmental body will have to police interconnections, as is done in the telephone industry. Sorne provision will also have to be made for preventing conflicting registrations, and the interaction between trademark law and domain name registrations will become more complex. These functions do not necessarily have to be carried out by a government-governinent regulation of Internet traffic in any form makes a lot of people nervous $\mathrm{s}^{345}$ and would also subject the administrator to constitutional constraints in the United States ${ }^{346}$ - but they will have to be accomplished somehow if domam name registration is to be competitive rather than proprietary. The U. S. government's proposal for non-profit oversight seems as sensible as any other. If cooperation continues to characterize the DNS system, it may be for the ironic reason that the law compels it.

Domain names are not the only fundamental part of Internet structure that turn out on inspection to be rather fragile. The system of exchanging and passing through data belonging to third parties has to date been cooperative and, more importantly, free-a process known as "peering." There are some signs that this is changing. In May 1997, UUNet Technologies, a major provider of Internet backbone connections, announced that it would charge fees to smaller Internet service providers for passing through their messages. ${ }^{347}$ If the four other major backbone providers follow suit, the cost of Internet access will undoubtedly rise. This is not necessarily a bad thing-the "hidden subsidy" structure of existing Internet transmissions may well prevent efficient access pricing and therefore discourage needed improvements in the backbones. ${ }^{348}$ But if access to the backbone is a commodity controlled by private companies who can exclude others at will, interoperability concerns similar to those in telephony may lead to demands for

345. See MiKe GodWin, After the CDA: OUR KO'd Radio Future? The Wired Last Trme (Working Paper, 1997); see also Steve Lohr, The Internet as Commerce: Who Pays, Under What Rules?, N.Y. Trmes, May 12, 1997, at D1 (calling it "inevitable" that "the Federal Government will become increasingly involved in the affairs of the Internet, even if that role is more as a referee than as a regulator").

346. For example, a government-mn domain name system would have to comply with the First Amendment, and would have to afford registrants due process of law before revoking their rights. See Gigante, supra note 328, at 429-30. On the other hand, a government actor would probably be free from antitrust liability under the state action immunity doctrine. See generally McGowan \& Lemley, supra note 161.

347. See Lohr, supra note 345, at D1.

348. See Hal R. Varian, Differential Pricing and Efficiency, FrRst MondaY, Aug 5, 1996 (visited Jan. 7, 1998) <http://www.firstmonday.dk/issues/issue2/different/>. 
government regulation of the circumstances in which access can be denied. ${ }^{349}$

The fragility of the cooperative "peering" arrangement that governs the exchange of messages may result in part from an economic implication of network markets. Because everyone on the network benefits from the improvements any one party makes to the infrastructure, the private incentive to increase one's bandwidth may be less than the social value of doing so. Kevin Werbach has referred to this as an example of "the tragedy of the commons." 350 This description may be misleading, however. The classic solution to a tragedy of the commons is to divide the commons into private property. Here, by contrast, that is likely to aggravate rather than solve the problem. Divided ownership will not internalize costs and benefits in a network market, as it would with real property. The only ways to internalize the external effects of the network are to centralize ownership or control, or to engage in cooperation across the entire network.

Finally, a word about the precise nature of the network effects at work here is im order. The network effect grows from the positive value placed on the ability to contact other people via the Internet and from the access to information from a wide variety of different sources. However, it isn't the case that people on the Internet want to communicate with everyone else on the network, just as they don't want to receive telephone calls from everyone on the telephone network. The death of Usenet as an effective means of communication resulted from an overabundance of participation coupled with the lack of limits on the relevance of that participation. In this sense, then, people want to interact with a subset of all those on the Internet, though they still may get a benefit from expanding the pool of people with whom they can potentially interact. Similarly, people may well want to access only a subset of information available on the Web, if that subset is filtered or tailored in such a way as to make it more useful to them. ${ }^{351}$ "Zoning" the Neteither by setting up private areas within it or by sectioning off entire areas by government mandate 352 -is not inconsistent with the idea that the Internet exhibits positive network effects. Rather, one must distinguish between structural barriers to access set up by inconsistent market standards and contextual barriers set up deliberately by the participants themselves.

349. Indeed, one company owner who was cut off by UUNet declared that "I am a proponent of some regulation in the Internet as soon as possible," calling regulation "critical to the Intemet's open and unrestricted development." Lohr, supra note 345, at D6.

350. Werbach, supra note 309 , at $450-51$.

35I. Anyone who has retrieved over 20,000 entries in an Altavista search will understand this problem.

352. On both types of "zoning," see Lessig, Constitution in Cyberspace, supra note 316, at 888-9. 
Network effects may still affect Internet governance. Scholars sometimes argue that Internet self-governance systems are the product of choice, because participants could "exit": quit the Internet in favor of an alternative computer network. ${ }^{353}$ But the right of "exit" is illusory in a strong network market. The fact that everyone wants to be connected to "the Internet"-and not some newly-created substitutemeans that individual "choice" of governance on the Internet is im fact rather weak, reduced to the level of the "choice" to take or leave a standard form contract term. ${ }^{354}$ It also means that the Internet is far easier for governments to regulate than it might at first appear, because access to the entire corpus of "the Internet" is so important to the whole endeavor.

It may be that we could set up sub-groups within the Internet, and that those subgroups could choose to govern themselves: excluding others, limiting access, and agreeing upon their own rules of behavior. This seems to be the model Johnson \& Post endorse. ${ }^{355}$ The model has its own set of problems: to the extent there is overlap between these online enclaves, or between the enclaves and the real world, autonomous decision-making within the enclave will have effects outside it. ${ }^{356}$ Network effects add another layer of external constraint. My enclave cannot decide to forego the DNS system unless it also decides to forego being on the Internet at all. And having opted to stay in the network, my enclave will probably also be constrained by the legal rules that govern that network. Certainly, I could not choose "ibm.com" as my new domain name. The real problem is that the "decentralized" law that cyberlibertarians favor for the Internet must coexist with a single set of rules that determine the structure of the Internet itself.

353. See, e.g. Post, supra note 312, art. 3, at II 1; David G. Post, Governing Cyberspace, 43 WAYNE L. REv. 155, 167 (1996) ("Mobility-our ability to move unhindered into and out of these individual networks with their distinct rule-sets--is a powerful guarantee that the resulting distribution of rules is a just one....").

354.. Indeed, the analogy is more precise than one might at first suspect, simce standard form contracts increasingly make up whatever "private governance" structure might be said to exist. See Robert L. Dunne, Deterring Unauthorized Access to Computers: Controlling Behavior in Cyberspace through a Contract Law Paradigm, 35 JuRIMETrics J. 1 (1994); Mark A. Lemley, Shrinkwraps in Cyberspace, 35 JuRIMETRICS J. 311 (1995).

355.. See David R. Johnson \& David G. Post, Law and Borders-The Rise of Law in Cyberspace, 48 Stan. L. Rev. 1367 (1996); David R. Johnson \& David G. Post, And How Shall the Net Be Governed?: A Meditation on the Relative Virtues of Decentralized, Emergent Law, in COORdinating THE INTERNET 62 (Brian Kahin \& James Keller eds., 1997).

356.. For example, I may want to join an enclave which has declared Microsoft's computer programs to be freely copyable, but Microsoft has not joined that enclave, and has legitimate grounds to object to our imposition of this rule even "upon ourselves." 


\section{F. Corporate Law}

Scholars have recently used network effects arguments to question basic assumptions of the contractarian paradigm that underlies much modern corporate legal theory. ${ }^{357}$ Most prominently, Michael Klausner (on his own and with Marcel Kahan) has argued that certain types of corporate contracts-and, more importantly, corporate law itself-are subject to imfluences analogous to network effects. ${ }^{358}$ This argument poses a provocative and far-reaching instance of the challenge of adapting network theory to legal ends. Indeed, insofar as the argument contemplates law as imbued with network effects, ${ }^{359}$ it stretches network theory further than any of the examples we have exainined thus far and makes the task of judicial adaptation even more delicate than usual.

In discussing applications of strategic behavior models to inform corporate scholarship in view of Easterbrook and Fischel's contractarian approach, Jason Johnston posed the question network theory presents for corporate law as follows:

[T] he great likelihood of increasing returns in the adoption of new legal innovations strongly suggests that legal evolution will be both potentially inefficient and unpredictable. On this theory, an initial advantage im the number of firms "adopting" a new legal innovation might then generate great advantages for that imnovation. An example of this is the refinement of legal rules due to increased frequency of litigation which has nothing to do with inherent advantages or disadvantages of those rules relative to other competing innovations. Legal innovations may exhibit "lock in" for a variety of other reasons, including externalities generated by cases establishing new precedent, and the costs

357.. On the contractarian paradigm, see, for example, FRANK H. EASTERBROOK \& DAvid R. Fischel, The Economic Structure of Corporate LaW (1991).

358.. See Klausner, supra note 5. Professor Klausner continues this analysis and combines it with his earlier work with Professor Kahan regarding event risk covenants in bond indentures in Kahan \& Klausner, Standardization, supra note 60; see also Mareel Kahan \& Michael Klausner, Antitakeover Provisions in Bonds: Bondholder Protection or Management Entrenchment?, 40 UCLA L. REv. 931 (1993) [hereinafter Kahan \& Klauser, Antitakeover]; Marcel Kahan \& Michael Klausner, Path Dependence in Corporate Contracting: Increasing Returns, Herd Behavior, and Cognitive Biases, 74 WASH. U. LQ. 347 (1996) [hereinafter Kahan \& Klauser, Path Dependence]. In addition to these works, Professor Gordon has explored the potential "positive externalities" inhering in standardization as a basis for federalizing certain corporate governance terms. See Gordon, supra note 44, at 1567-69; see also Lucian Arye Bebchuck, Federalism and the Corporation: The Desirable Limits on State Competition in Corporate Law, 105 HARv. L. REv. 1435, 1493-94 (1992) (questioning strength of such externalities); David Chamy, Competition among Jurisdictions in Formulating Corporate Law Rules: An American Perspective on the "Race to the Bottom" in the European Communities, 32 HaRv. INT'L L.J. 423, 442-45 (1991) (arguing that positive externalities are an important benefit of standardization among jurisdictions).

359.. We use "law" broadly here, to encompass the reported decisions and statutes comprising the nominal body of "corporate law" as well as social practices which they foster or discourage. 
incurred by consumers-such as corporate counsel-in switching from one legal "product" to another. ${ }^{360}$

Professor Klausner's discussion of network theory in corporate law is the most extensive exploration of these issues, and of the problem of legal adaptation of network theory in a setting of relatively weak effects, ${ }^{361}$ and we therefore consider it at some length here. We do not wish to overstate the case Klausner makes, however, and pause here to note that his analysis is explicitly exploratory in nature and does not call for sweeping revisions in doctrine or for aggressive governmental intervention, as have some proponents of network theory in other fields. ${ }^{362}$ Professor Klausner's model shows how network effects might produce externalities in corporate and contract law though, as he acknowledges, the data do not support strong conclusions on this point.

At a theoretical level, Klausner contends that the contractarian paradigm underlying much modern corporate theory "fails to take account of network externalities, a type of market failure that may be uncommon in product markets, but possibly pervasive in the market for corporate contract terms." ${ }^{363}$ This failure in turn supports his conclusion that, to the extent network effects are significant, "the contractarian paradigm provides an incomplete account of the role of corporate law and the process by which states compete to sell corporate charters."364 Klausner argues that network theory may warrant some relatively modest change in existing corporate statutes. ${ }^{365}$ Though Klausner rightly views network effects as "simply another type of externality that should be taken into account in analyzing corporate contracts," he believes that "the existence of this particular type of externality requires a basic shift in how we conceptualize corporate law-from an aid to corporate contract drafting to a standard-setting system analogous to technical standards in other fields."

Klausner's work is theoretical, rigorous, and ambitious; while we disagree with some of the inferences he draws, our main purpose here is to question the degree to which network effects cause the potentially suboptimal circumstances Klausner identifies, and thereby illustrate the difficulties inherent in using network theory to inform legal policy. Consistent with our general focus on the prospects for useful adaptation

360. Jason Scott Johnston, The Influence of The Nature of the Firm on the Theory of Corporate Law, 18 J. CORP. L. 213, 242 (1993).

361. By which we mean that each of Klausner's effects are mdirect and relatively far removed from prototypical network goods such as telephones or interoperable compatible goods such as software or VCRs.

362. See supra notes $68-268$ and accompanying text.

363. Klausner, supra note 5, at 771 (citations omitted).

364. Id. at 759.

365. See id. at $832,837-40$.

366. Id. at $791 \mathrm{n} .110$. 
of network theory in law, our interest is in whether, as a practical matter, network effects are likely to require modifications in either contractarian theory or corporate law.

\section{The Contractarian Paradigm}

Harkening back to fundamental Coasean insights, ${ }^{367}$ much of modern corporate theory views firms as webs of contracts involving shareholders, creditors, managers, and employees. ${ }^{368}$ The contractarian view takes maximization of firm value as the goal of corporate law. Firms must compete in capital, labor, and product markets, and the competitive pressures these markets exert are presumed to produce the set of contracts that maximizes the firm's value. As a normative matter, the contractarian view implies that corporate law should not impose mandatory terms, which would preclude contracting on a given topic, unless such terms are justified by identifiable flaws in the bargaming process. ${ }^{369}$ The presumption of efficient corporate contracting is held with varying strength by various commentators. There is some disagreement regarding which identifiable breakdowns in bargaining warrant mandatory terms, and whether the connections among participants in the corporate enterprise may be deemed contracts in a meaningful legal sense. ${ }^{370}$ Setting the latter debate aside for present purposes, we seek to determine whether network theory identifies a systemic tendency toward suboptimal contracting.

Klausner rightly notes that the contractarian paradigm assumes that "the value of a corporate contract term is unrelated to the number of firms that adopt the term."371 As Klausner argues, to the degree a firm's choice of governance of contractual terms is based upon the choices of other firms, "market forces cannot be relied upon to promote socially optimal corporate contracts."372 It would not necessarily follow, however, that a shift to some alternative presumption, such as

367. See RH. COASE, THE FIRM, THE MARKET, AND THE LAw 33-55 (1988) (discussing the question of when market transactions are replaced by intra-firm transactions); lan Ayres, Making $a$ Difference: The Contractual Contributions of Easterbrook and Fischel, 59 U. CHI. L. REV. 1391, 1395 (1992) (noting Coasean foundations of contractarian theory).

368. The standard summary of this position is EASTERBROOK \& FisCHEL, supra note 357, at 1215. The term "nexus of contracts" may be traced to Michael C. Jensen \& William H. Meckling, Theory of the Firm: Managerial Behavior, Agency Costs and Ownership Structure, 3 J. Fn. EcoN. 305, 310-11 (1976). The nexus concept itself is commonly traced to Armen A. Alchian \& Harold Demsetz, Production, Information Costs, and Economic Organization, 62 AM. EcoN Rev. 777, 77778 (1972).

369. See, e.g., EASTERBROOK \& FISCHEL, supra note 368, at 15; Klausner, supra note 5, at 760.

370. On this point see Melvin Aron Eisenberg, Contractarianism without Contracts: A Response to Professor Mc Chesney, 90 Colum. L. REv. 1321 (1990) and Fred S. McChesney, Contractarianism Without Contracts? Yet Another Critique of Eisenberg, 90 CoLUM. L. REv. 1332 (1990).

371. Klausner, supra note 5 , at 761 .

372. Id. at 759 . 
adoption of mandatory rules or different types of contractual defaults, would be warranted. As Professor Trebilcock has noted, "[t]he problem of third-party effects from exchange relationships is pervasive and not aberrational. Almost every transaction one can conceive of is likely to impose costs on third parties." 373 Klausner quite appropriately refrains from making this analytical leap. Such a decision would depend not only on the difficulties with the contractarian paradigm, but also on the existence of evidence supporting a finding of systematic (non-random) deviations from optinal contracting and the viability of judicial or governunental initiatives designed to remedy any systematically suboptimal outcoines.

\section{Potential Challenges from Network Theory}

Klausner posits several reasons why the value of a corporate contract term might increase with the number of firms adopting the term. One group of these reasons, which he calls "interpretive effects," is based on the notion that more frequent adoption of a given term will increase the probability that the term will be subject to future interpretation by courts. That judicial interpretation in turn will presumably lead to greater clarity in potentially ambiguous terms. ${ }^{374}$ Klausner distinguishes interpretive effects from the inherent benefits of a term, comprised of its linguistic clarity and all practices and precedents that exist at the time a firm is required to adopt or reject the term..$^{375}$

In addition to the idea of risk reduction through enhanced clarity of contract terms, Klausner applies his network effects analogy to

373. Michael J. Trebilcock, The Limts of Freedom of Contract 58 (1993); see also Richard A. Posner, Economic Analysis of LAw 12 (3d ed. 1986) ("[M]ost transactions (and if not a single transaction then a series of like transactions) have effects on third parties, if no more than by changing the price of other goods .....").

374. See id. at 776; see also Gordon, supra note 44, at $1566 \mathrm{n} .56$; Johnston, supra note 360, at 242.

375. As Klausner states:

At the time a firm adopts a contract term, past precedents are not network benefits. They are part of the term's currently understood meaning and, in network externality vocabulary, are therefore elements of its inherent benefit.

Klausner, supra note 5 , at 776 n.61. As almost a reciprocal of this point, Klausner argues that the more widely a given term is adopted, the more likely it will be to give rise to accepted standards of conduct within the business community that may provide further clarity with respect to implementation of the term. Business professionals and business lawyers take a considerable degree of comfort in following procedures used by other prestigious firms, which in turn may have originated with, or at least received the approbation of, the courts. Thus, as Klausner rightly notes, if courts are willing to accept an investment bank's faimess opinion at face value as evidence that a board of directors properly discharged its duty of care in evaluating a control proposal, then such opinions will be routinely recommended by corporate lawyers; if nothing else, the recommendation will show the lawyer's own diligence and provide a record that can be defended in court by citation to favorable precedent. See id. at 781-82; Claire A. Hill, Fool Me Twice, Shame on ME, Or How Corporate LAWYers Learn From Their Experience (Working Paper, 1998). 
certain economies associated with lawyers, accountants, and investment bankers. ${ }^{376}$ Klausner rightly notes that such firms lower transaction costs in capital markets by developing contract terms, norms of behavior, and similar structures to facilitate transactions even where the parties themselves have little or no experience. To the extent any of these structures becomes a standard, as occurred with the Generally Accepted Accounting Principles, there will be some inertia weighing against either the adoption of any alternative standard, or any deviation from the standard through adoption of a term customized to fit the needs of a particular firm. ${ }^{377}$ Such deviation would require a firm to forego the learning economies derived from its intermediaries' experience with standard terms. Klausner analogizes such econornies to the production of goods compatible with a network good. ${ }^{378}$ As a related but distinct point, Klausner identifies learning economies anong investors as "marketing network effects." To the extent investors have become familiar with standard terms, Klausner suggests that issuers might be reluctant to depart from such terms out of concern that investors would not price the nonstandard term properly, would fear that other investors would not do so (creating liquidity problems in secondary markets), or would discount the terms to compensate for the cost of analyzing their value. ${ }^{379}$

These concepts must be treated with care. Leaving aside corporate charters and focusing on corporate contract terms to which deliberative consent presumably has been given, such as some terms of bond indentures, contracts are fundamentally artifacts (hopefully) embodying the understanding of the contracting parties. Unlike microprocessors or software, contracts do not theunselves process data; unlike telephone networks they do not theinselves convey communications. The value of contracts rests ultimately on human understanding and interpretation. Accordingly, the processes of interpretation and applied understanding will always be at work when a contractual term is at issue. Each of the effects Klausner discusses should be modeled as a service or input compatible with the contract terms-the "network good." Klausner does an estimable job of parsing different elements of interpretation and understanding, and exploriug the manner in which widespread adoption of similar terms affects these elements. Because these eleinents ultimately converge in an act or acts of interpretation bringing the contract to life, however, the task of attributing causal significance to any one of the interpretive elements, and thus of inferring the presence of network

376. See Klausner, supra note 5, at 782-84.

377. The flip side of this, of course, is that information presented in GAAP form is more valuable to those familiar with GAAP and what it represents than is information presented in another form.

378. See Klausner, supra note 5 , at 782 n.82.

379. See id. at 785 . 
effects and deriving desirable modifications of the law to deal with any inefficiencies, is more complicated than would be the case for goods that require relatively less human intervention to provide value to a user.

Klausner derives from these concepts a model describing possible suboptimal contracting. Network theory itself supports any of four different outcomes: where standardization is desirable, the optimal standard may be adopted, a suboptimal standard may be adopted, or the optimal standard may be adopted but becomes suboptimal over time for reasons of inertia and collective action problems. Alternatively, where standardization is undesirable, a standard may be adopted or maintained, by definition a suboptimal outcome, or no standard may emerge, by definition an optimal outcome..$^{380}$

In Klausner's model, when firms place the saine value on terms (standardization is desirable), firms may nevertheless adopt suboptimal terms (either one suboptimal standard or multiple different terms) that have high inherent value relative to the present value (discounted for the risk that other firms will not adopt it) of an alternative term that would have greater value if it became a standard through adoptions over time. Conversely, when firms place different values on a term, they may nevertheless adopt a standard term that differs from the firm-specific optimal term simply to obtain the benefits of the standard. ${ }^{381}$ Firms may, for example, place the same value on a term defining circumstances in which a firm will be deemed to have sold or leased "substantially all" of its assets. If there is one optimal construction, firms may forego it for one having a higher inherent value-perhaps a relatively clear but inflexible term. Alternatively, if different definitions would be optimal for different firms, all firms might nevertheless persist in using a boilerplate standard because of accumulated precedent or the familiarity of a firm's advisors with existing definitions. Consistent with this array of possible outcomes, Klausner is careful to note that the implications of possible network effects for the law are indeterminate.

In light of the analytical difficulties resulting from such indeterminacy, Klausner's recommendations for change in corporate law are appropriately limited in nature and scope: he calls for further empirical research, and suggests that corporate law might profitably gravitate away from a paradigm of relatively specific default rules, designed to mimic the outcome of a hypothetical bargaining process, and instead move toward a standard-setting paradigm offering menus of relatively tailored

380. See Farrell \& Saloner, supra note 8.

381. See Klausner, supra note 5, at 813. 
default rules. ${ }^{382} \mathrm{He}$ also suggests that network theory may help explain Delaware's dominance in the market for corporate charters. ${ }^{383}$

Before analyzing these arguments in detail, we wish to make two points about Klausner's use of the network analogy in corporate theory and his later work with Marcel Kahan on event-risk bond covenants. First, we applaud the general nature of the inquiry. Without wishing to engage even briefly in the debate over what aspects of economic theory properly fall under such rubrics as "transaction cost economics" versus "neoclassical economics" or the "new institutional economics," we work from the premise that the Coasean origins of contractarian corporate theory dictate that the theory should be focused on the costs of forming and altering corporate contracts-be they governance teruns or debt issues. ${ }^{385}$ Klausner and Kahan rightly recognize that their exploration of possible influences of network effects on corporate contracting behavior is a step in that direction. They seek

to crack open further the black box of the corporation by enhancing the understanding of why corporate contracts look the way they look, by critically examining the extent to which atomistic corporate contracting can be expected to produce a socially optimal degree of standardization, and by investigating institutional factors that may overcome the potentially suboptimal influences of atomistic corporate contracting. ${ }^{386}$

The exploration of network theory in corporate contracting is thus precisely the sort of work that is required to test and provide substance to contractarian theory. Though we would attribute the economic behavior they examine less to network effects than to other related economic influences, we wholeheartedly agree with the need to examine more closely the actual contracting behavior of firuns and the economic forces that influence such behavior. ${ }^{387}$

382. See id. at 839 .

383. See id. at 842 .

384. For more on this debate, see Richard A. POSNER, OVERCOMIng LAw 426-43 (1995).

385. As Oliver Williamson has pointed out, Coase himself did not dictate the level of specificity at which transaction cost analysis should take place. See Williamson, supra note 18 , at 230 . But Coase's general approach and call for empirical research into corporate contracts suggcst agreement with the concept of designating transactions themselves as the appropriate unit of analysis. See Ronald H. CoAse, Essa ys ON Economics ANd Economists 13 (1994).

386. Kahan \& Klausner, Standardization, supra note 60 , at 716.

387. Or, as Oliver Williamson has described the endeavor of operationalizing transaction cost theory, the task entails "(1) identifying the critical ways in which transactions differ and explicating their economic significance; (2) identifying the key features that distinguish alternative governance structures, and developing the basic tradeoffs in moving from one to another; (3) working out the logic of the discriminating match, whereby transactions are aligned with governance structures in a way that economizes on transaction costs; and (4) doing empirical studies that bear on the predictions that are derived from these operationalization efforts." Williamson, supra note 18 , at 230 . 
Second, it is important to distinguish between the economic influences Kahan and Klausner group under the heading of "learning benefits" and those they analogize to network benefits. The difference is temporal. Learning benefits refer to the value imbued in a given term through previous experience. Such benefits include simple drafting efficiencies, ${ }^{388}$ reduced uncertainty due to previous judicial interpretation, general familiarity with a term, and, possibly, development of behavioral norms within the financial community ${ }^{389}$ As noted above, for purposes of network theory, Klausner categorizes these as inherent rather than network benefits, reserving the latter term for those benefits accruing through contemporaneous use of a term by other firms. ${ }^{390}$

Particularly with respect to interpretive benefits, this distinction is extraordinarily fine and may be untenable. One may price an asset that has not generated past earnings solely by predicting future income streams and discounting for risk; one would be unlikely to replicate that analysis for an asset that had generated income in the past. A more likely approach (absent a material change in circumstances) would incorporate prior performance in the analysis. Similarly, as a practical matter, when called upon to decide whether to adopt or adhere to a given term, the view of lawyers and bankers with respect to construction of the term will be influenced as much by past experience (inherent benefits) as by future expectations (network benefits). And future expectations are themselves in significant part a product of past experience. Given that a relatively high ratio of network to inherent benefits is what distingnishes network goods froin other goods, the difficulty of drawing this distinction renders analysis of interpretive effects highly problematic. ${ }^{391}$ Even with respect to service and marketing effects, network effects will likely be closely related to the historical development of a market; ${ }^{392}$ it therefore will be very difficult to evaluate the relative importance of inherent and network benefits in a given case.

While Klausner's model and analysis rigorously explore the potential for using network theory to inform corporate legal analysis, our more general analysis of network theory provides a slightly different perspective, and a correspondingly different emphasis on the importance of network theory for either the contractarian paradigm or existing legal rules. Based on our more general analysis, and subject as always to further empirical work in the field, we are skeptical that the

388. Though the cost of reproducing terms in the computer age is low, and the incremental efficiencies of duplicating prior forms are therefore slight.

389. See Kahan \& Klausner, Standardization, supra note 60, at 719-24.

390. See id. at 724-25.

391. We discuss this point in greater detail in section F.6, infra.

392. See supra notes 49-51 and accompanying text (noting importance of history in network markets). 
evidence Klausner (and Klausner and Kahan) find in support of their analogy in fact represents evidence of network effects, and in particular of the claim that network effects might be the cause of the potentially suboptimal circumstances they identify. We accordingly assign less weight to the degree to which network theory either weakens the presumptions of the contractarian paradigm or warrants changes in existing legal rules. In brief, as explained in the following sections, we believe that network effects in corporate law will be difficult to identify as such, will be weak where they can be found, and will likely be subject to amelioration through market forces.

\section{Interpretive Effects}

The interpretive network effects Klausner identifies are grounded in the economics of information, and therefore apply in those circumstances in which information and information costs play an important role in market structure-which is to say they apply in virtually all circumstances involving transactions. ${ }^{393} \mathrm{He}$ characterizes these effects as a combination of the inherent imprecision of langnage and the principle that imprecision, here another word for risk, tends to reduce the value of any contract. ${ }^{394}$ In short, uncertainty is costly, and if widespread use of a contract term can reduce uncertainty, then the term's value will increase to a level beyond its intrinsic value simply because it was widely adopted. If Klausner has identified systemic, network-based flaws in actual contracting behavior, the relevance of his insights will be widespread if not ubiquitous in cases involving commonly-used contracts. ${ }^{395}$

In terms of network theory, the value of a contract term is comprised of its inherent benefits-the innate clarity of the term and the value of past experience and judicial precedent-plus the present value of the potential for greater clarity in the future through litigation, which value increases as more firms adopt the term, and which comprises the network benefit. ${ }^{396}$ Klausner hypothesizes that firms shifting away from established standard terms will incur potentially material opportunity

393. Cf. James Boyle, Shamans, Software, and SpleEns: Law and the Construction OF THE INFORM ATION SOCIETY 41-46 (1996) (noting the pervasiveness of information cost limits in modern economics). But see Lemley, supra note 203, at $890-94$ (contesting Boyle's conclusions on this score).

394. See Gordon, supra note 358, at 1566 (noting that imprecision of nonstandard corporate charter terms will create costs due to risk but arguing that such costs are unproblematic from a contractarian perspective because they will be internalized by the firm adopting the nonstandard term).

395. This indeed is the thesis of Klausner's later discussion of these points with Kahan, which sets out to diseuss "the economics of boilerplate" as such. See Kahan \& Klausner, Standardization, supra note 60 , at 716 .

396. And, to be fair, less the present value of the probability that widespread adoption will reduce clarity through the publication of inconsistent opinions. 
costs in the amount of the present value of increased clarity for some such standards through future litigation. By hypothesis, that value will be much lower for nonstandard terms than for standard terms. ${ }^{397}$

As a practical matter, we do not see how to parse a firm's valuation of the cost of losing inherent benefits (innate clarity plus precedents and behavioral norms) and the firm's valuation of the opportunity cost of possible future clarifications. To the extent snch parsing could be done, however, we tend to doubt that the costs of contracting around default rules or standardized contract terms, imcluding both the costs to negotiate and memorialize the nonstandard term and the loss of future interpretive benefits, will be very high relative to the inherent benefits of any given term at any given point in time. At a minimum, we would expect firms to place more weight on existing precedents than the uncertain possibility of future judicial clarification. ${ }^{398}$ We consequently suspect that interpretive network effects associated with either default or standardized terms will be relatively weak, i.e., unlikely to represent a systemic fiaw in the presumption of independent contracting. ${ }^{399}$

Assuming for the moinent, however, that one can isolate inherent and network benefits with respect to a given term, the key variable with interpretive effects is the clarity of a term's meaning. The value of relatively specific terms-snch as a cumulative voting default, the number of shares authorized, permissible debt ratios, or the proportion of votes required to approve a merger-is inherent, a point Klausner rightly recognizes. $^{400}$ It follows that even if firms exhibit a high degree of

397. This view implies that we should be concerned with the structure of default rules-whether they should be "tailored" (drafted with an eye toward a specific firm or subset of firms with a particular salient characteristic) or "off-the-rack" (drafted to mimic the terms a majority or plurality of firms would agree upon if they bargained over a term). Klausner argues that "[t]he presence of network externalities in corporate contract terms militates in favor of tailoring to some degree" because even if an off-the-rack default "is value maximizing for a majority or plurality of firms, its ability to promote the formation of a contractual network can nonetheless lead to a socially suboptimal contract equilibrium." Klausner, supra note 5 , at 832 . There is much to explore in this idea, but lere we simply note the issue and leave the exploration for another day.

398. If this intuition is correct, the concept of interpretive network benefits requires a reconceptualization of network theory as well as corporate law, for it defines as a network good contract terms for which inherent benefits can be expected to be systematically higher than network benefits.

399. We can dispense with inherent switehing costs relatively quickly. In contrast to cases involving large capital investment in a particular network technology, the actual expenses incurred in adopting a non-standard term are not likely to be material. A contract term is not a computer program: discarding an old one in favor of a new one does not require the investment of any particular resources, or the conversion of old data. And while contract terms might theoretically be protected by copyright or even patent law, in practice lawyers freely copy contractual innovations from other lawyers without paying for them.

400. For example, if contracts could be written and interpreted by computers in binary code, the terms themselves would not be subject to network effects; nor would contract terms governed by mathematics, such as a bond covenant preventing an issuer from assuming debt beyond a certain ratio 
standardization with respect to specific terms, such standardization does not necessarily (or even likely) imply the presence of network effects. Relatively specific provisions will by definition have relatively little value to gain through possible clarification by litigation or other forms of interpretation. This holds true both because the process of interpretation would have little to add to the clarity of such terms, and because such terms would be relatively unlikely to give rise to disputes requiring interpretation. The opportunity cost of departing from a specific standard would therefore be quite low, as would the risk of a socially suboptimal equilibrium with respect to such terms.

The case for interpretive effects therefore rests on the value of possible future clarification of less precise terms-such as fiduciary duties, or the rule that incumbent management may oppose unwanted tender offers so long as the measures adopted are "reasonable in relation to the threat posed." ${ }^{401}$ Such rules are more likely to give rise to litigation precisely because they are vague, and therefore could potentially support multiple courses of action. The prospects for future litigation to clarify such terms will be stronger but, as a practical matter, we doubt whether such prospects pose a significant challenge to the presumptions of the contractarian paradigm, or warrant changes in corporate governance statutes.

While we do not take issue with the general proposition that interpretation through litigation may add some value to open-ended contract terms by mcreasing their clarity, there are fairly strict limits to the value of such effects, particularly when one counts the existing body of precedent as an inherent benefit. Again assuming that one can draw this distinction, we doubt that the marginal gains in clarity that might be obtained through future litigation are high enough to create benefits sufficient to lock firms into any particular term, particularly when compared to whatever incentives the firm has based on the existing body of precedent and experience. This is particularly true when the inherent meaning of the potential terms differs: no firm will choose a rule that will disadvantage it because that rule is likely to be clearer. In other words, given relatively high inherent benefits, as a practical matter there will be no way to tell whether a firm adopts or retains a given term because of any identifiable network benefits, and thus no way to conclude that network benefits are the cause of any particular equilibrium.

There is in any event no a priori reason to believe that a significant portion of the disputes over the meaning of a term will in fact be resolved through litigation and, more specifically, through reported

relative to its assets or cash flow. Klausner's model incorporates this prediction as well. See Klausner, supra note 5, at 763-65.

401. Unocal Corp. v. Mesa Petroleum, Co., 493 A.2d 946, 949 (Del. 1985). 
appellate decisions. The high cost of litigation, the reputational cost of being known as soineone who sues their business partners, the probability in the relatively small world of corporate finance that two parties will desire to do business in the future, and the availability of less expensive means of alternative dispute resolution that do not produce precedential decisions all combine to make the litigation model one of last resort in many instances. ${ }^{402}$ In light of such disincentives to litigate disputes through appellate courts, even a nontrivial increase in the probability that a term will be litigated may not increase the likelihood of enhanced clarity very much..$^{403}$

In addition, even reported decisions may not add much to the inherent value of open-ended terms. In at least some instances, openended governance terms-particularly governance defaults for large, publicly-traded firms with multiple debt obligations-will resemble the antitrust statutes: majestically general language overlaying a byzantine mixture of economic relationships that are poorly understood by the parties to the various relationships, to say nothing of jurists called upon to make sense of multiple competing positions. Such general language has not historically been a hospitable medium for the development of clear legal meaning, regardless of the number of times courts interpret a term. Indeed, when courts interpret general terms such as "reasonable" to achieve what they perceive to be a just result in a particular case, ${ }^{404}$ there may well be an inverse relationship between the probability of obtaining a reported opinion addressing a given term and any expectation that the term will be further clarified. ${ }^{405}$

Broad concepts such as the duty of care encompass so many different situations that it will often be difficult simply to identify what issues the courts believe they are addressing. Should one view

402. For a detailed elaboration of this point, see Edward L. Rubin, The Nonjudicial Life of Contract: Beyond the Shadow of the Law, 90 Nw. U.L. REv. 107, 118-22 (1995).

403. As Klausner points out, however, to the extent material gains in clarity may be obtained through litigation, the small probability that any given dispute will lead to a reported decision supports the view that any interpretive effects will accrue throughout the full range of adoptions of that term. For interpretive effects, in other words, any network benefits would not be inframarginal, as any benefits associated with legal service and marketing effects almost certainly are. See infra text accompanying notes $418-453$.

404. Which is not to say that a court seeking such a result would hand down inefficient decisions. As Ian Ayres has noted, "[c]ourts can promote efficiency by imposing contingent contractual obligations ex post that corporate stakeholders are in practice unable to contract for ex ante." Ayres, supra note 367 , at 1404 .

405. See, e.g., POSNER, supra note 22, at 6 (discussing the failure of antitrust law to achieve much clarity in evaluating complex economic arguments). Klausner of course does not contend that adoption of a standard will lead to "clarity" in any abstract, normative sense; his argument advances the more limited and more realistic point that widespread adoption will yield marginal increases in clarity. Again, in this instance our view reflects a differing assessment of the likely magnitude of such effects rather than with the logic underlying Klausner's argument as such. 
Smith v. Van Gorkum, ${ }^{406}$ for example, as a standard duty of care case or as a subspecies pertaining to control transactions? ${ }^{407}$ Would Time's asserted right to preserve corporate policy fare as well for a tire manufacturer as it did when blended with rhetorical appeals to editorial independence and the assertedly unique role of Time in American society ${ }^{408}$ Tests under which such concepts are evaluated tend to be accordingly flexible. The Delaware Supreme Court in Time, for example, praised the Unocal test ${ }^{409}$ for its elasticity: "The usefulness of Unocal as an analytical tool is precisely its flexibility in the face of a variety of fact scenarios. Unocal is not intended as an abstract standard; neither is it a structured and mechanistic procedure of appraisal." $\$$

These limitations are reflected in the principal example of interpretive effects Klausner cites for the proposition that network effects cause suboptimal contracting: the "apparently widespread use of "plain vanilla' charters, and hence the wholesale adoption of default rules, as opposed to customized corporate charters." 411 Klausner is careful to note that this example is to some degree speculative, based on the intuition that charters merely embracing the law of a given state are more widely adopted than the heterogeneity among firms suggests they should be. ${ }^{412}$ As he puts it, interpretive network effects analysis "suggests that there may be terms for which some degree of customization is clearly permis-

406. 488 A.2d 858 (Del. 1985). The firm at issue in the case was Trans Union Corporation, and the case is therefore sometimes referred to as the "Trans Union" case.

407. See Ronald J. GILson \& Bernard S. Black, The Law and Finance of Corporate ACQUisitions 1055 (2nd ed. 1995) (noting that "part of the puzzle is whether Trans Union really is a business judgment case at all"); Jonathan R. Macey \& Geofrey P. Miller, Trans Union Reconsidered, 98 YALE LJ. 127, 128 (1988).

408. See Paramount Communications, Inc. v. Time Inc., 571 A.2d 1140 (Del. 1990).

409. See Unocal Corp. v. Mesa Petroleum, 493 A.2d 946 (Del. 1985).

410. 571 A.2d at 1153 . Klausner recognizes that a fair amount of litigation in the Delaware courts brought hittle in the way of certainty to the rules governing permissible defenses to takeover attempts opposed by incumbent management. See Klausner, supra note 5 , at 762 n.12. More recent cases appear for the moment to have clarified some aspects of the test, while continuing to emphasize flexibility. As Unocal shows, fact-specificity may long persist even within a genre of cases. Taking Chancellor Allen's analysis in Interco as an example, see Capital City Assocs. v. Interco, Inc., 551 A.2d 787 (Del. Ct. Chanc. 1988). Where management and a bidder present competing break-up offers, the question whether an offer poses a threat may (and arguably should, notwithstanding the Delaware Supreme Court's chastising words in Paramount $I$ ) rest on the economic characteristics of the offer. Where offers compete, a share exchange offer may or may not be close to the equivalent of an all-cash offer; an offer incorporating some mixture of cash, stock, and debt similarly may or may not be close to the equivalent of an all-cash offer. The number of variables necessary to the determination whether a threat exists increases in the latter two cases; with such increases comes the increased possibility of distinguishing precedent, and increased complexity in determining whether the clarity of a governance term has been enhanced, diminished, or unaffected by a given decision.

41I. Klausner, supra note 5, at 822 . Klausner also presumes that some interpretive network effects existed with respect to certain indenture terms, though his discussion of the model debenture indenture provisions pertains more to legal service effects than to interpretive effects. See id. at 817 18.

412. See id. at 822 . 
sible and potentially value enhancing, and yet firms will still decline to customize those terms." ${ }^{313}$

It is not clear why interpretive network effects carry inuch explanatory power with respect to the adoption of "plain vanilla" charters, or the more general failure of firms to customize their charters to embrace alternatives to state-law default rules, particularly when the body of precedent and business norms relating to such terms is an inherent benefit of those terms at the time of adoption. The idea that a firm adopting a charter would value the prospect of future clarification of existing rules more than the extant precedent seems counterintuitive..$^{414}$ On the other hand, very little about the operation of interpretive effects is clear, as shown by a more specific example Klausner uses to illustrate suboptinal contracting. He suggests that the iteration of the Unocal test adopted by the American Law Institute's Principles of Corporate Governance may not have been adopted by inany firms (which presumably retained "plain vanilla" charters) because the ALI's version is "replete with open-ended formulations" and thus a large portion of the provision's value lies in future interpretations, which are in turn a function of the number of firms adopting the test. ${ }^{415}$

Yet, as Klausner notes, the ALI's test is simnltaneously "broadly consistent with the Unocal test" ${ }^{\prime \prime 16}$ and clearer than Unocal in important ways. If relative clarity (in present value terms) is in fact the desideratuin of firms choosing governance provisions, one would not expect interpretive effects to prevent firms from adopting the ALI's test: both that test and Unocal offer future benefits of clarity through litigation, while the ALI's version offers some marginal advantage in clarity over the status quo. The ALI test effectively incorporates much of the existing precedent interpreting Unocal and, where it does not, its departures tend toward relative clarity. Given the broad consistency of the ALI and Unocal tests, the ALI test would appear to have a greater inherent value (incorporation of existing precedent and relatively greater innate clarity where existing precedent was eschewed) than the original Unocal test. As Klausner notes, the ALI test is also open-ended in material ways, and

413. Id. at 822-23.

414. In addition, to the degree that firms view charters as a whole, rather than individually, they could quite rationally conclude that the value of the charter was on balance inherent (more in specific than ambiguous terms) or that the cost of sorting the different types of terms and tailoring the latter exceeded any benefits. In either event, firms would not be swayed in their decision by relatively lower-value interpretive benefits. To be fair, however, even if there are more specific terms in a charter than general terms, the latter are likely to be more important in a quahtative sense.

415. See Klausner, supra note 5 , at 824 .

416. Id. at 823, 823-24 (noting that the ALI test "dispenses with the vague and inapposite 'corporate policy and effectiveness' language" of the Unocal test and "explicitly states that the directors' action must be in the best interests of the 'corporation and the shareholders' and it defines that term to mean the enhancement of profitability over the long term"). 
thus should accrue interpretive benefits at least roughly equivalent to those expected for Unocal itself.417 Yet firms have not shifted. The answer may be a simple agency cost story: inanagers may prefer the greater freedoin to inaneuver offered by the Unocal test and, having control of such matters, refuse to shift. Or there inay be another explanation. Whatever the reason, interpretive network benefits would appear to be an unlikely causal candidate. Indeed, such effects could suggest the opposite result.

\section{Service Providers}

The network analogy is further complicated by the operation of what Klausner calls service-related network effects, which are in essence inputs to the operation of the governance, or debt terms at which Klausner's (and Klausner and Kahan's) arguments are directed. ${ }^{418}$ In operational terms, these effects involve the business behavior of law firms and imvestment banks who, often unlike the corporations for whom they work, are repeat players in corporate financial transactions. In Klausner's view, economies associated with scale and learning effects may enable such firms to provide more efficient services for widelyadopted terms than for customized terms. Firms adopting the standard will enjoy the benefits of such efficiencies, while firms adopting customized terms may encounter relatively greater costs. ${ }^{419}$

We suspect that such economies do not reflect very strong network effects, and likely will not be the cause of any suboptimal contracts. As discussed above, legal and investinent banking services are coinpatible with "networks" of terms; Klausner thus rightly conceives of service effects as economies of scale in an input or complementary good, rather

417. If Unocal accrued greater interpretive benefits, then the failure of firms to switch to thc ALI's test would be attributable to network benefits, but in a sense opposed to the manner in which Klausner analyzes the case.

418. These services should be considered inputs regardless whether they are obtained from retained advisers or from employees of a firm. Whether a given firm will bring such functions inhouse is presumptively a function of its cost structure, but the service rendered is an input to the network good-the term-in either case.

419. See Klausner, supra note 5, at 782. In addition, though not a part of Klausner's network analogy, to the extent lawyers and bankers effectively dictate the governance or debt terms a firm will adopt, the lawyers' and bankers' own interests will tend to drive firms to adopt standard terms. As noted above, Johnston couches corporate attorneys as the consumers of such terms. See Johnston, supra note 360 , at 242 . It is possible that lawyers and bankers would enforce a suboptimal standard because other lawyers and bankers did so, even if the standard had few or no nctwork benefits to clients actually adopting governance terms. See Kalian \& Klausner, Path Dependence, supra note 358. Hence, "nctwork benefits" to lawyers and bankers would appear as agency costs to firms. Though analytically distinct from sucl value as may inhere in governance terms themselves, the incentives of lawyers and bankers could in theory reinforce the tendency toward standardization implied by Klausner's interpretation of network theory. 
than as direct network effects. ${ }^{420}$ In other words, multiple adoptions of a term may provide a sufficiently large base for service providers to realize such learning or scale economies as are available. Legal and financial service economies of scale are thus indirect "market-mediated" effects, to borrow froin Farrell \& Saloner, ${ }^{421}$ and are materially weaker than direct network effects, or even indirect network effects in the presence of actual interoperability, as is the case with computer software.

Regardless of the abstract strength of such effects, however, we see very little reason to believe that service effects will entice firms to deviate from socially optimal contracts. Nor do such effects warrant an alteration in existing law. Klausner recognizes that legal service effects are likely to peak earlier than interpretive effects; ${ }^{422}$ we agree with this point but would extend it further. Both legal and investment banking service effects would likely peak at a level far below the extent of terms in the market as a whole, resembling what Liebowitz and Margolis dub "inframarginal externality."

In other words, one would expect the learning curve of lawyers and bankers with respect to model indenture terms, for example, to drop fairly rapidly and to become immaterial well short of the extent of such terms in the market as a whole. Beyond a fairly modest level, therefore, additional issuers adopting such terms are unlikely to create incremental gains in legal or financial service efficiencies and are thus unlikely to confer benefits on other firms using those terms. In addition, both by traming and experience, lawyers and bankers should be capable of interpreting a wide array of terms, and therefore should be able to operate (shift) among terms at a relatively modest cost. The marginal difference in efficiency between advice on standard and non-standard terms is therefore unlikely to be very large regardless of learning effects. In any event, if service effects are in fact inframarginal, they will likely be internalized through competition among lawyers and bankers, so there is little reason to believe that the premises of the contractarian paradigm are materially weakened, or that positive corporate law is in need of change. ${ }^{424}$

420. This distinction becomes even harder to draw with respect to lawyers and bankers because, as a practical matter, it is likely more often than not the case that lawyers and/or investment bankers are the drafters of the terms, the entities that choose which terms will be adopted and, should a dispute arise, the entities that will interpret the terms for a firm.

421. See Farrell \& Saloner, supra note 8, at 70.

422. See Klausner, supra note 5, at 784 n.87.

423. Liebowitz \& Margolis, Uncommon Tragedy, supra note 5, at 140-41.

424. This is particularly true with respect to terms with high inherent value. If such value arose from innate clarity, then a professional would likely need little more than the education necessary to enter the profession to deal adequately with the term. If such value arose through a body of precedent, one would expect lawyers in particular, and bankers to a lesser extent, to familiarize themselves with the precedent as part of the normal continuing education activities rcquired to stay 
Indeed, competition among lawyers and bankers may ameliorate the lock-m problem that is the prototypical inefficiency associated with network markets. Such professionals compete on a variety of grounds and will seek every opportunity to distinguish themselves on grounds other than price, including expertise. Thus, firms have an incentive to internalize the costs of familiarizing themselves with a variety of terms. ${ }^{425}$ In addition, such firms often compete with one another by offering innovative services and products such as hostile takeover expertise, ${ }^{426}$ poison pills, ${ }^{427}$ or bonds with "poison put" provisions. ${ }^{428}$ Competition through innovation may internalize much of the cost of innovation, to some degree overcoming collective action problems that might otherwise block transitions among standards in other circumstances. ${ }^{429}$ Though the evidence is anecdotal, experience among intermediaries over the past twenty years suggests that competitive forces will in fact facilitate innovation. ${ }^{430}$

competitive in highly-competitive markets. There are many ways to fail in a pitch for business; displaying ignorance of recent developments is near the top of the list.

425. Cf. HLL, supra note 375 , at $1 \mathrm{n} .2$ (noting that in practice forms are less standardized even within firms than one might expect).

426. See infra note 430 (noting first-mover advantages accruing to the Skadden and Wachtell firms through earlier practice in hostile transactions).

427. See GilsoN \& BLACK, supra note 407, at 740-41 (noting origin of poison pill with Wachtell firm and quoting memorandum from Wachtell to clients describing its "share purchase rights plan").

428. See Kahan \& Klausner, Antitakeover, supra note 358, at 738 (discussing poison puts).

429. Kahan and Klausner recognize this point with respect to poison puts as well. See id.

430. In this sense, competition among intermediaries in financial markets is the competitive equivalent of software reverse-engineering or "bridge" programs written to facilitate transition among applications. The rise of both law firms and investment bankers willing to compete by expanding the range of services offered and undertaking aggressive maneuvers they previously eschewed provides some reasonably persuasive evidence that the profit motive will be strong enough in enough intermediaries to overcome risk aversion and thereby facilitate innovation. A good account of this dynamic may be found in Ron Chernow, THE House of Morgan: AN AMERICAN B ANKIng DYNaSTY AND THE Rise OF MOdern Finance 599-600 (1990). As Chernow describes the process by which Morgan Stanley entered the business of advising chents on hostile transactions, work previously scorned by old-line firms, an influential partner "made a pitch for hostile takeovers as an irresistible trend that was fair to sharebolders, if not always to mariagement. The argnment of inevitability was probably the decisive one. As one partner recalls, "The debate was, if we don't do what our clients want, somebody else will." Chernow goes on to note the influence of law firms that were formed by castoffs from white-shoe firms and those whom the major firms would not hire-in the 1940 s and 1950 s this wide range of unacceptable applicants included Jews.

At this juncture, Morgan Stanley made another unorthodox decision. Like Morgan Guaranty, the firm had long relied on the white-glove law firm of Davis, Polk, and Wardwell, which had looked on takeover work as vulgar and avoided it. With Morgan Stanley partners terrified of lawsuits ensuing from takeover work, they now wanted a tough, seasoned specialist. Greenhill [the influential partner mentioned above] insisted on hiring the experi: enced Joe Flom, of Skadden, Arps, Slate Meagber \& Flom .... [Flom had] pioneered in hostile takeovers in the 1950's, when Skadden, Arps was still a humble, four-man operation. For twenty years, he thrived on the scraps from law firms that were too haughty or too dignified to conduct hostile raids... . When Flom was made a special counsel to Morgan Stanley, there were stormy scenes with Davis, Polk partners, who were dceply offended by the decision. Whatever its other consequences, the trend in bostile takcovers democratized the New York legal world and provided an opening in Wall Street for Jewish lawyers. Both 
We believe that Klausner's own example of service effects producing externalities - the terms of corporate indentures-is more consistent with these explanations than with network effects. The corporate indenture story centers on the American Bar Foundation's Corporate Trust Indenture project, which was designed to standardize the language of certain indenture terms that were unlikely to vary in value relative to different firms ("boilerplate") but that had previously differed anong firms. ${ }^{431}$ According to Klausner, "prior to the Project's inception, bond indenture terms were suboptimally diverse. The complexity of the terms and the procedures they could trigger created legal network externalities." ${ }^{332}$ By this, Klausner means that "the optimal contractual equilibrium with respect to boilerplate terms was one in which all firms adopted the same boilerplate. As a result of uncoordinated contracting decisions of individual firms and their lawyers, however, suboptinnal diversity existed.",433 The suboptimality here is a failure to standardize, and thus to capture available positive externalities.

The state of bond indentures before the ABA model was drafted likely does not reflect materially suboptinnal contracting, particularly in light of the increasing returns to standardization implied by network theory. Absent marginal transaction costs exceeding the marginal benefits to standardization, the potential for increased value should drive network markets toward standardization. ${ }^{434}$ Why then, if the value of corporate indentures would have increased through standardization, did firms persist in using a suboptimally diverse array of terms before the American Bar Association intervened? The idea of uniformity certainly

Joe Flom and Marty Lipton of Wachtell, Lipton, Rosen \& Katz profited from the early refusal of old-line Wasp firms to sully their hands with takeovers.

Id.

431. See, e.g., Churchill Rodgers, The Corporate Trust Indenture Project, 20 Bus. LAw. 551 (1964).

432. Klausner, supra note 5 , at $817-18$.

433. Id.

434. Recall the characterization adopted by Katz and Shapiro: "[i]n markets with network effects, there is a natural tendency toward de facto standardization, which means everyone using the same system." Katz \& Shapiro, Systems Competition, supra note 25, at 105 . There is some contemporaneous evidence that cost-justified standardization was occurring prior to the ABA project. Writing in 1931, Karl Llewellyn referred to the history by which merchants developed principles of free transfer and third-party rights im bills of exchange before the law recognized such concepts. He went on to note that

In a business sense, though not so strictly in law, a very similar standardizing and simplifying process occurs in the investment market today. The investor looks for six or seven familiar standard features in a stock or bond, irrespective of the length of the mortgage indenture or articles of incorporation-six or seven features similar enough to be summed up in Poor or Moody.

Karl N. Llewellyn, What Price Contract?-An Essay in Perspective, 40 YALE LJ. 704, 721 (1931). Llewellyn's observations imply that coordination was achieved where its benefits exceeded its costs, and was dcemed by the relevant parties not worth the effort with respect to other terms. 
was familiar to corporate lawyers: in the wake of the Trust Indenture Act of $1939,{ }^{435}$ qualified indentures were required to include a variety of statutorily-mandated terms, which by definition could not vary in material ways among indentures. ${ }^{436}$

While we recognize that some value may have been added to indentures by the ABA's Model Debenture Indenture, though subject to the constraints on the interpretive effects concept discussed above, we see the slow adoption of this standard as evidence that the benefits to standardization were slight relative to the cost of standardization. On the cost side, the absence of efficient data reproduction and storage technology such as copiers or computers may simply have prompted each law firm or underwriter to continue using its own forms (a sort of technology-driven path dependence). As we see it, if firms are locked into suboptimally diverse terms for reasons of firm-specific path dependence, that state of affairs tends to suggest that the benefits to standardization, and thus externalities associated with a failure to standardize, are likely to be shight. Network theory here may suggest the desirability of reducing transaction costs, though that goal would seem desirable, all else being equal, without regard to network theory.

\section{Marketing Effects}

Klausner also discusses the rise and fall of event-risk or "poison put" bond covenants, a topic that his later paper with Marcel Kahan explores in greater detail. These covenants provide the best context for discussing what Klausner describes as "marketing network effects"essentially learning economies of scale among investors. ${ }^{437}$ During the relatively brief period when they were common, event-risk covenants provided additional security for bondholders against a diminution of the value of their bonds due to a change in control of the issuer, such as occurred with the leveraged buyout of RJR-Nabisco. ${ }^{438}$ Klausner notes that such covenants were rapidly adopted in many bond issues during 1988 and 1989, and then declined in use as hostile takeover activity diminished in the early 1990 s. $^{439}$ For Klausner, this pattern is "consistent with the presence of network exterualities in these covenants. Both their rise and fall followed the bandwagon patteru associated with network

435. 15 U.S.C. § 77aaa et seq..

436. Indeed, in the course of seeking expert witnesses, one of us (McGowan) spoke to a longtime indenture lawyer and former SEC commissioner who recounted hours spent as a young lawyer respondent-reading (with his wife and newborn child, no less) new indentures against old to ensure that the TIA would not be violated by typographical errors. Whatever hardships technology has inflicted on young lawyers in recent years, and there are plenty, we at least have been spared that indignity.

437. See Kahan \& Klausner, Standardization, supra note 60, at 726.

438. See Kahan \& Klausner, Antitakeover, supra note 358, at 934.

439. See Klausner, supra note 5, at 819. 
externalities. In addition, most details of the covenant quickly became standardized to a great extent, again indicating the presence of network externalities." 440

We view the poison put story as tending to contradict rather than support the network theory. The bond indentures into which event-risk covenants were introduced were presumably by and large the progeny of the American Bar Foundation Model Debenture Indenture, which Klausner views as an instance of efficient standardization. If such indentures actually represented network standards, one would expect some degree of inertia inhibiting departures from the standard via the introduction of new and untested provisions. ${ }^{411}$ The rapid rise of such covenants, which Kahan and Klausner describe as being "fairly complex and differ[ing] significantly from other covenants," 442 thus requires some explanation.

The answer may lie in the specificity of that portion of the covenants that departed from the standard indenture. Kahan and Klausner believe that, though the risk of loss in bond value from issuer control transactions was known before 1988, and soine event-risk covenants existed, the widespread attention and large decrease in bond values surrounding the RJR leveraged buyout "Inay have increased the perceived risk of takeover-related losses and thereby enhanced the inherent value of the covenant. ${ }^{.443}$ Bearing in mind that the degree to which network theory identifies factors motivating behavior, and thus informs legal analysis, an increase in the inherent value of a term likely would increase the probability that it would be adopted but also would tend to diminish the significance of any associated network benefits. In other words, high inherent benefit was a sufficient reason for firms to adopt the terms, regardless of what other firms did. Kahan and Klausner characterize the covenants as "relatively specific,"444 and we agree with that characterization. ${ }^{445}$ As noted above, the specific nature of such covenants supports the view that the value of the terms was largely inherent.

440. Id.

441. With respect to corporate contracts, this is likely the only cost worth considering. Drafting costs (including both counsel's time and that of their word processing department) are most likely trivial relative to the amount of any given debt issue.

442. Kahan \& Klausner, Standardization, supra note 60 , at 746 n.72.

443. Id. at 745 .

444. Id. at 746 n.72.

445. Kahan and Klausner do, however, envision that litigation could produce interpretive effects with respect to the triggers of an event-risk covenant: "[i]ssues could have arisen, for example, related to the calculation of the threshold shareholding or the measure of substantiality in an asset sale under the designated event provision." Id. at $746 \mathrm{n.72}$. We are skeptical that a sufficient number of disputes would arise under such provisions to yield meaningful increments in the clarity of such provisions. The shareholding threshold (the percentage of stock that, when acquired by a third party, would trigger a put) is a mathematical provision that should be susceptible to adequate clarification at the drafting stage. While the sale of all or substantially all assets is indeed a vaguer term, it is also a 
Nevertheless, as the quotation from Klausner points out; network theory does predict that once a new standard emerges it will be adopted very rapidly-that is the essence of the "tipping" concern. Given the specificity of the terms, rapid adoption of a standard alone provides weak evidence in support of interpretive effects: high inherent value would be enough to attract firms to adopt such terms. Suppose, however, that the RJR transaction did in fact awaken the inarket-or more precisely, the muestment banking community-to the possibilities for a new (or at least revised) product that could be sold to both investors and management as protection against a common enemy. To us, this would seem to reflect a standard competitive dynamic and, perhaps, bounded rationality on the part of investors in evaluating bonds prior to 1988 . Kahan and Klausner look at the event from a different perspective, arguing that press reports of the decline in RJR bond values created an expectation that future debt issues would include event-risk covenants and that " an expectation of widespread use may have increased confidence among early-adopting firms, and early bond purchasers, that the covenant would be priced in the secondary market if bonds with the covenant were sold several years later." ${ }^{446}$ They believe this expectation would have made earlier investors more amenable to lower interest rates, thus lowering issuers' costs of capital. ${ }^{477}$

In terms of Klausner's model, this argument rests primarily on marketing. effects, which are in essence learning economies among investors. As with learning economies associated with service providers, we would expect these economies to be infrainarginal-only a relatively modest fraction of all investors need familiarize themselves with such terms in order to provide liquidity in secondary trading. Past the point at which liquidity may be maintained, additional investors do not confer value on earlier investors by familiarizing themselves with the terms. Moreover, because the unique aspects of event-risk covenants were relatively specific, there is no reason to expect learning costs to have been very high. Investor-learning economies would therefore likely peak very early indeed. This factor may also explain why the covenants fell out of use so quickly: if the perceived rise in inherent value were triggered by investors' perceptions of the risk of highly-leveraged takeover activity, a fall in that risk would diminish the perceived inherent value of the covenants. The high ratio of inherent to possible network value seems better able to explain both the rise and fall of event-risk

term included in the American Bar Foundation Model Debenture Indenture (\$ 8-1) and therefore cannot be considered to have any effects unique to event-risk covenants. What value it had would be more properly characterized as inherent, obtained through incorporation of terms that draw on precedent from model debenturcs and from asset-sale provisions such as Del. Gen. Corp. L. § 271.

446. Kahan \& Klausner, Standardization, supra note 60, at 746.

447. See id. 
covenants than does a theory resting on network effects. Event-risk bonds therefore provide weak evidence for a finding that network effects caused suboptimal contracts to be formed. ${ }^{448}$

We find further support for this view in Kahan and Klausner's contention that event-risk covenants were affected by switching costs. Their findings are based on "intra-company consistency," Ineaning that, once a firm had issued debt including event-risk covenants, it was unlikely to change its formulation regardless of innovations in such covenants elsewhere in the market: "[O]nce a company adopted an event-risk covenant, in essentially all cases it declined to adopt any subsequent improvements." Kahan and Klausner view this as "strong support for the hypothesis that switching costs were present" and thus "indirect evidence for the presence of learning or network benefits." While such behavior is consistent with an explanation based upon intrafirm learning curves and the high inherent benefits of such terms, it is inconsistent with network theory, which predicts that, as standards become established, firms will gravitate to them in order to obtain the benefits of standardization. If the ratio of inherent to network benefits is such that firms are content to adhere to terms once adopted, then there is considerable reason to question whether a "standard" term in the market should be considered a standard for purposes of network theory.

We thus return to the problem of isolating the causal forces behind the observed behavior. Kahan and Klausner characterize the effects in the alternative-as showing "the presence of learning or network benefits." ${ }^{251}$ Standard network theory suggests that the former effects are likely at work here (which would be consistent with a finding of high inherent value), but that the latter are not. ${ }^{452}$ For these reasons, we

448. Kahan and Klausner note that the major bond rating agencies began to rate the protective qualities of event risk covenants once significant numbers of the covenants began to appear, noting that "[ $t]$ he rating agencies could presumably justify doing this only if a critical mass of bonds with these covenants were issued." Id, at 746 n.73. As with investors themselves, there is little reason to believe that the scale necessary to amortize the agencies' costs of familiarizing themselves with event-risk covenants was sufficiently large to suggest the presence of a network effect.

449. Id. at 752.

450. Id. Kahan and Klausner discount the possible explanation that each firm had adopted uniquely suitable covenants on the ground that each firm retained its covenants in the face of materially improved alternatives. See id. at n.83. We have no reason to disagree with this conclusion and would not find it surprising for a firm simply to continue with prior issues it had successfully sold until the market would no longer buy them at an acceptable (if not optimal) price.

451. Id., at 752.

452. Kahan and Klausner go on to describe the switching costs effects they find as "[i]nternal learning and network benefits." Id. at 753. The concept of network effects within a firm is more likely a concept related to productive efficiency than to positive utility payoffs among users of a network good. Indeed, as noted above, the problem of network formation for strong network goods such as fax machines was originally solved by internalization within large firms. We would disagree, however, with the idea that intra-firm contracting patterns that ran counter to market standards could be considered a network effect. 
disagree with Kahan and Klausner's conjecture that " $[t]$ he presence of such internal learning and network benefits may in turn be suggestive of similar (albeit lower) external learning and network benefits." ${ }^{453}$ To the extent firms adhere to their own forms because of intra-firm learning curves, which is what Kahan and Klausner's data imply, such adherence will tend to produce heterogeneous terms, not networks.

\section{Implications for Corporate Governance}

As noted above, the inferences for corporate law that Klausner draws from network theory are not sweeping. Klausner advocates a reconceptualization of the contractarian paradigm because, in his view, the presence of network externalities undermines the a priori case for presuming that contracts actually formed in the market are optinnal. For the reasons set.forth above, we see little reason to conclude that the econormic influences Klausner identifies as network effects create systematic deviations warranting modification of the contractarian presuinption. Klausner's principal recommendation for corporate law involves reconceptualizing the contractarian paradigm, gravitating away froin the notion of corporate statutes as unitary products of a hypothetical bargaining process and toward a notion of statutes as the product of a standard-setting process. Klausner thus suggests drafting corporate statutes to include menus of possible terms rather than a single inajoritarian (or plurality) default term. ${ }^{454}$

Our analysis in the preceding Sections suggests that whatever network effects exist in corporate governance or contract terms are inframarginal, with the exception of interpretive effects, which are of ambiguous strength and indeterminate implication. We thus see no reason to suppose that network theory compels the conclusion that corporate contracting is systematically suboptimal or that menus are necessary to enhance the value of corporate contracts. ${ }^{455}$ By the same token, however, we see no reason actively to oppose the menu concept. ${ }^{456}$ The only

453. Id.

454. See Klausner, supra note 5, at 839-40.

455. Klausner states that "for terms with significant network externalities, the difference between default and mandatory terms is more one of degree than one of kind." Id. at 837 n.242. As we do not read Klausner to conclude that any of the effects lie identifies are in fact significant with respect to any particular term, there seems relatively little reason to question whether statutory defaults are more mandates than options.

456. Some existing statutes include menu-like provisions, such as section 204 of the California corporation law, CAL. CORP. CODE $\$ 204$ (West 1990), which provides for optional provisions in articles of incorporation (as opposed to the provisions required by section 202, CAL. CORP. CODE $\S 202$ (West 1990)) and lists several options. We read Klausner's proposal, however, to be more substantive and to provide more explicit choices than are reflected in section 204. Cf. Robert Rasmussen, Debtor's Choice: A Menu Approach to Corporate Bankruptcy, 71 TEx. L. REV. 51 (1992) (proposing menu options for corporate bankruptcy). 
real downside risk would appear to be that the availability of various items on the menu would induce too much diversity where uniformity would be preferable, or increase marginal transaction costs more than marginal benefits. If we are right to suspect that network effects im this area are weak, this risk seems slight. Indeed, our analysis suggests that, given the likely inframarginal nature of service network effects, competition among lawyers and bankers, and the often decisive role they play in choosing terms, there is no clear reason why law firms and imvestment banks would not already offer a variety of alternatives were it efficient to do so. With respect to terms material to firms, the varieties of instruments and terms trading in financial markets suggests that this is in fact occurring.

Klausner also examines the question of corporate federalism in light of network economics. He suggests that network effects may explain why Delaware remams the jurisdiction of choice for large firms when so many other states mimic Delaware's law. ${ }^{457}$ Couching the question as one of the costs of remaining incorporated in Delaware or reincorporating elsewhere, ${ }^{488}$ the networks argument adds to the debate interpretive effects (the opportunity costs of future clarification of governance terms) and legal service effects. ${ }^{459}$ For the reasons explained above, we doubt legal service effects create efficiencies sufficient to distort contracting; to the extent laws of other states mimic Delaware's, the marginal cost of learning such laws will be minimal and, given competition among firms and the inframarginal nature of such effects, likely internalized. ${ }^{460}$ The desire to avoid such costs is therefore unlikely to play much of a role in maintaining Delaware's lead.

The role of opportunity costs from interpretive effects is more difficult to judge. The first problem is agam the relative strength of inherent and network effects. Because the existing case law is an inherent benefit of a Delaware charter, ${ }^{461}$ firms have a strong incentive to

457. See Klausner, supra note 5 , at 842 .

458. Professor Black argues that reincorporation costs are low, Bernard S. Black, Is Corporate Law Trivial?: A Political and Economic Analysis, 84 Nw. U.L. REv. 542, 558 (1990), while professor Romano believes they are material, see Roberta Romano, The Genus of American Corporate LAw 34-35 (1993).

459. See Klausner, supra note 5, at 843-44.

460. The possibility remains, lowever, that the parochial interests of the Delaware bar play an important role in ensuring that Delaware remains responsive to the needs of managers who clioose a firm's state of incorporation. See Jonathan R. Macey \& Geoffrey P. Miller, Toward an Interest-Group Theory of Delaware Corporate Law, 65 TEx. L. Rev. 469 (1987).

461. As Klausner states,

[T] he network benefits associated with a contract term consist of future judicial interpretations. Existing case law is an inherent benefit and can, at least in theory, be incorporated into a contract term explicitly or by reference. Delaware's current stock of precedents is thus an inherent benefit of the Delaware charter, not a network benefit. The network benefit of the Delaware charter is the present value of future judicial interpretations and depends directly on the number of firms incorporated in Delaware. 
incorporate in Delaware on that basis alone. Moreover, as noted above, it is unrealistic to expect that firms will price the value of future Delaware precedents (network benefits) without significant reference to the past behavior of Delaware courts (inherent benefits) as an indicator of that value. Klausner is right to contend that if interpretive network benefits exist they will extend through most if not all firms adopting such charters, and thus that the large number of firms presently incorporated in Delaware may represent a benefit other states cannot replicate merely by mimicking Delaware law. ${ }^{462}$ But given the difficulty of distinguishing between decisions based on extant precedent and those based on interpretive network effects, our intuition that firms themselves do not draw such a distinction, and the degree to which corporate attorneys influence a firm's choice of its state of incorporation and may do so for their own parochial reasons, there is no reliable way to conclude that firms would alter their incorporation choices if interpretive network benefits were absent.

\section{Conclusion}

The application of network theory to corporate law is a good example of scholarly use of emerging economic concepts to test the viability of an ascendant legal paradigm, in this case contractarianism. Corporate law provides an environment where network theory can be tested in a relatively weak form, at least when compared to telephony or operating system software. Application of the theory in this environment shows the importance of separating inherent from network benefits and identifying the relative weight of such benefits when asking whether network theory is likely to inform us about market behavior the law may seek to regulate. Such application also demonstrates the difficulty of this task as one moves farther away from actual networks, the potential difficulty of imterpreting market data using network principles, and the indeterminate nature of network theory with respect to many legal questions. The models developed by Klausner and Kahan provide potential aid in analysis of the pervasive problem of third-party effects from contracting, though we believe the data to date do not establish that network effects produce systemically suboptimal contracting.

\section{G. Contract Terms}

As the discussion in the previous Section makes clear, the analysis of network theory with respect to corporate law-at least within the contractarian paradigm-overlaps in significant part with the analysis of contract law. Theories of standardized terms in corporate contracts are

Klausner, supra note 5, at 844 n.263.

462. See id. at 845 . 
largely generalizable to other sorts of contracts; so too are the limitations of these theories. However, for purposes of network theory, we will distinguish between form agreements and negotiated agreements. As Avery Katz has pointed out, form agreements may be conceptualized as an input into any given exchange that lowers the costs of transacting by avoiding the cost of negotiating over recurring terms. ${ }^{463}$ The savings are particularly large among repeat players. Form agreenents might exhibit the sort of interpretive network effects discussed above with respect to corporate charter terms. The adoption of the Uniform Commercial Code, albeit with inaterial inodifications by various states, reflects a recognition of potential positive interpretive network effects.

As discussed above, however, ${ }^{464}$ from a lock-in perspective, there is little reason to expect strong network effects in negotiated contract terms. From a cost perspective, a firm inay value certainty that all contracts of a particular class have the same terms, even if in the abstract those terms are marginally inferior to newly developed terms. Specific terms will have high inherent value that can gain little from additional interpretations of the contract. More open-ended terms inay gam some clarity through adjudication, but such clarity will be constrained by the mcreased number of variables introduced by broader terms and the relatively few number of cases that yield reported decisions. For example, consider one of the most standardized (indeed, mandatory) "default" rules in contract law-the implied covenant of good faith and fair dealimg. ${ }^{465}$ The inplied covenant is an open-ended term that effectively establishes a totality of the circumstances test, which by definition produces different outcomes in different circumstances. Indeed, despite abundant litigation on this single contract "term," few would argue that its meaning is certain today. Even the nature of the circumstances that are relevant varies from case to case. What is fair conduct for dealing in durable goods may not be fair conduct for goods with shorter hives, and the standard imposed on vendors in certain industries (e.g., insurance) may be stricter than the general standard. ${ }^{466}$ Fact-specificity is a significant limit on the "certainty" supplied by common contract terms; ask any contract litigator. ${ }^{467}$

463. See Avery W. Katz, Standard Form Contracts, in The New Palsgrave Dictionary of LAW AND ECONOMICs (forthcoming 1998); see also HinL, supra note 375, at 2 (asserting that "[o]ver time, the form [contract] evolves, mostly for the better"; but noting the persistence of bad contract language).

464. See supra notes $420-421$ and accompanying text.

465. See, e.g., U.C.C. \$ 1-203 (1995).

466. Similarly, from a governance perspective, conduct that might satisfy a fiduciary duty to corporate shareholders (or creditors, in the case of insolvency) might not satisfy such a duty in the case of a limited partnership, with its different taxation structure and different doctrinal traditions.

467. Kahan and Klausner do not suggest otherwise. See Kahan \& Klausner, Path Dependence, supra note 358. 
Furthermore, firms may adopt certain standard terms for a variety of reasons, none of which necessarily imply the existence of network effects. Financial contracts, for example, are negotiated as a whole, and parties seeking agreement on an important point may not want to expend negotiating capital to revise relatively unimportant terms. ${ }^{468}$ If a standard term imposes an opportunity cost on one party, that cost may be recouped through other terms more favorable to the party. It would then be difficult to conclude that the contract as a whole was suboptimal. ${ }^{469} \mathrm{~A}$ similar cost/benefit analysis will apply to most negotiated contract terms.

Both within corporate and contract law, courts must confront the question of how to facilitate formation of efficient contracts at the lowest cost. As noted above, there is little reason to expect adherence to suboptimal terms, as measured by the marginal costs and benefits of change, at least for relatively large transactions in which firms are advised by sophisticated intermediaries. If we consider securities as simply one form of contract, the market for such contract terms is a highly dynamic one in which new products such as derivatives are coinmonly introduced to compete both with one another and with more traditional investments. ${ }^{470}$ Again, it is not clear that network effects have much to offer in this market. In the presence of weak network effects, one would expect intermediaries such as investment bankers to have a variety of alternatives to offer, each of which enjoyed some degree of "network" value. In the presence of strong effects, one would expect menus of alternative terms to be superfluous. As with corporate law generally, we would expect, at most, modest network effects subject to significant constraints, so that alternative menu-based systems would have little discernible effect on the contracts actually drafted in the inarket.

Contracts of adhesion-those drafted entirely by one party and offered on a take-it-or-leave-it basis-deserve separate treatment. If one party cannot bargain over contract terms, adhesion contracts will likely standardize around terms favorable to the drafting party. ${ }^{471}$ Indeed, since

468. See HILL, supra note 375.

469. We can attest from anecdotal evidence that parties will sometimes insist on the inclusion of language accepted by reputable investment banking institutions in previous deals because such language is marginally beneficial to a party and its prior acceptance by a reputable intermediary provides a credible negotiating position. The other party to the transaction may have other deal points it considers more important, and therefore may choose not to fight over the "standard" provision in order to obtain its preferred language in some other portion of the agreement. This type of logrolling over individual contract terms may potentially perpetuate standard language in certain instances, but does not necessarily rcflect suboptimal contracting.

470. See Henry T.C. Hu, Hedging Expectations: "Derivative Reality" and the Law and Finance of the Corporate Objective, 73 TEX. L REv. 985, 988 (1995).

471. Rubin cites as an example self-help terms imposed by vendors and lenders. The existence of strong cost barriers to litigating such terms helps perpetuate them, even in circumstances where they would probably be unenforceable if taken to court. See Rubin, supra note 402 , at 125-31. 
the only means of "bargaining" available to non-drafting parties is the threat to go to a competitor offering better terms, drafting parties may have a strong incentive to standardize their terms to squelch competition. Rob Merges has referred to such uniform, cartel-like teruns within an industry as "private legislation." "network effect" of a sort-those who draft contracts of adhesion with one-sided terms benefit if their competitors adopt the same one-sided terms. ${ }^{43}$ Unless the term itself is so important to the other side that they are willing to forego any transaction in the market, they will be stuck with the uniform term.

In this model, standardization becomes the desirable outcome for the drafting parties, but not necessarily the optimal outcome for society. Where private standardization eliminates competition over contract terms, mandatory (or at least stricter) statutory default rules may serve as a viable alternative. Statutory defaults would lead to more socially optimal contracts if (but only if) they include contract terms with higher social value than those selected through private standardization. Although we have not undertaken a comprehensive study, we suspect there will be at least a few cases in which this would be the likely outcome. The modern legislative trend, however, appears to be in the opposite direction. Draft UCC Article $2 \mathrm{~B},{ }^{474}$ dealing broadly with transactions in "information," including intellectual property, would adopt virtually no mandatory rules and would make it much easier to change default rules through contracts of adhesion (or even without the express agreement of the other party). ${ }^{475}$

Contract law also figures into debates over network theory in another way-as a potential remedy to problems caused by network effects. Contracts underlie virtually all of modern cominerce, including cominerce in network markets. As the Supreme Court's Kodak opinion points out, when antitrust aficionados express confidence that "the market will fix" some anticompetitive problem, they are implicitly in-

472. See Robert P. Merges, Intellectual Property and the Costs of Commercial Exchange: $A$ Review Essay, 93 Mrch. L. Rev. 1570, $1611-12$ (1995); see also Friedrich Kessler, Contracts of Adhesion-Some Thoughts About Freedom of Contract, 43 CoLum. L. REv. 629, 640 (1943); Mark A. Lemley, Shrinkwraps in Cyberspace, 35 JuRIMETRics J. 311, 319-20 (1995).

473. In fact, however, this effect most resembles a traditional cartel in which all participants have individual incentives to cheat and a collective incentive not to cheat. The benefits to cartel participation do in fact depend on how many other existing members of the industry join the cartel. On the other hand, a cartel is unlike a network in that expanding the number of participants in the market is a bad thing rather than a good thing for existing firms.

474. The April 1998 draft (the most recent one) is available from the University of Houston Web server Uniform Commercial Code Article $2 B$ Revision Home Page (visited Apr. 24, 1998) shttp://www.law.uh.edu/ucc2b/s.

475. See U.C.C. art. 2B §§ 2B-112, 208 (April 1998 draft); see also David A. Rice, Digital Information as Property and Product: U.C.C. Article 2B, 22 U. DAYTON L. REv. 621, 643-45 (1997) (criticizing this aspect of the draft). 
voking the operation of contract law, and thus the problems inherent in the process of contracting. ${ }^{476}$ Thus, the mechanism of contract implements many economic strategies relating to networks. For example, firms that seek to predate in order to acquire market share often do so through agreements. Additionally, firms may seek to draft intellectual property licenses that indirectly contribute to their market sharewitness Microsoft's former practice of charging a license for its operating system to hardware manufacturers based on the number of hardware units sold, regardless of whether Microsoft's software was installed. ${ }^{477}$

One might attempt to resolve these problems within contract doctrine itself, rather than intervening with antitrust law or changing intellectual property rules. Various contract doctrines-and certainly contract's normative principles-might prove the best way to address some of the problems present in network markets. For example, as noted above, network markets are particularly susceptible to consumer expectations. Because consumers prefer to own the standard product, an announcement by the standard-setting firm might cause consumers to forego purchases of other products in anticipation of the new standard. If the announcement turns out to fall into the category of "vaporware," an announcement of a product might induce reliance that, with proper analysis and limitation, could lead to a cognizable claim under contractbased theories. ${ }^{478}$ Firms that announce open architecture in order to induce the production of complementary goods that help the firm establish itself as a standard could be estopped from "closing" future iterations of their software in the event third parties invested capital and brought value to the network as a whole through the creation of complementary goods. ${ }^{49}$

We hasten to say that these are merely illustrations. Each requires much further analysis and, with the exception of the examples we discuss below, that analysis is beyond the scope of this Article. The point remaims, however, that one cannot speak intelligently about remedies to problems of network theories without considering contract law. We will return to this point in Part III.

\section{H. Conclusions}

We offer these detailed exainples of network effects in legal theory in large part to deinonstrate their diversity. Network effects can range from extremely strong, as in the Internet and telephony examples, to

476. See Eastman Kodak Co. v. Image Technical Servs., 504 U.S. 451, 479 (1992).

477. See supra notes 71-77 and accompanying text (discussing challenges to this practice).

478. Cf. supra notes $91-95$ and accompanying text (treating such claims under antitrust law).

479. One of the authors has previously argued for such a result in the context of the Dasa General case. See McGowan, supra note 11, at 836-841. 
relatively weak, as in the corporations and contract law examples. The effects inay be of different types: compare the "true" network of telephony with the "virtual" networks of certain software markets. And the goals of the law are often different. Network effects may have more significance where the law attempts to determine, regulate, or police the structure of the market (as it does in antitrust and telephony) than where its goals are wholly or partially independent, as in corporate law and (to a lesser extent) intellectual property law. In these cases, what network effects exist may simply be tangential to the legal rules that surround them.

These difficulties make it problematic to talk about "the role" of network economic effects in legal argument. There are-and should be-many different roles. That doesn't mean that economic theory can offer no gnidance to the law, however. In Part III, we begin the development of a structured way of thinking about the legal implications of network economic effects.

\section{III}

Deriving Principles for Judicial Treatment OF NETWORK EFFECTS

A nnifying theme in these cases is disunity. As we observed in Part II, "network effects" do not constitute a single phenomenon. Rather, different types of network effects exist, and they vary in strength. Courts and legislatures faced with claims of network effects must have some mechanism for distinguishing "good" from "bad" arguments (in the positive sense of identifying whether a network effect really exists), and for distinguishing "good" from "bad" effects (in the normative sense of deciding whether a particular network effect is beneficial or harmful, and what if anything should be done about it).

In this Part, we suggest factors courts might use to evaluate a claim that a market (or the law itself) is characterized by network effects. It is of course impossible to offer anything like a full taxonomy of network effects claims. The recent nature of network economic arguments and the continuing debates among economists about their implications show that the economics of networks is itself still under construction. Further, we do not purport to have identified all or even most of the potential roles network effects may play in legal argument. Nonetheless, in the pages that follow, we offer a uumber of yardsticks courts might use to measure such claims. 


\section{A. Nature and Strength of the Effects}

A court presented with an argument based in network theory must scrutinize the claimed effect closely. As we have seen, a wide variety of different network economic effects can be lumped under the label "network externality." Even before analyzing evidence of market factors, a court confronted with a network effect argument must determine the type of network effect at issue. An actual network, such as the interconnection effects associated with telephone networks, is much stronger than a virtual network or a general positive feedback relationship. This difference in strength manifests itself in various ways. First, actual networks are much more likely than virtual networks or positive feedback markets to converge on a single standard, and that standard is more likely to be universal. Network effects are not always absolute; sometimes multiple products can each build a core of users with its own partial network effect. For example, despite the dominance of the Microsoft operating systems, there remains a core group of dedicated Macintosh users who are locked in to their own (losing) network standard. Similarly, Betamax owners kept Beta-coinpatible videos in stores long after it was clear that Beta would not be the dominant VCR standard. But this sort of coexistence is less and less likely as the strength of the network effect grows. Economic factors may incline consumers to choose the Web browser that most others are choosing, but they can also resist that inclination if they have a good enough reason. They are much less likely to be able (or willing) to buck the trend toward a universal telephone network by joining an incompatible rival network.

Second, a court must also focus on the strength of the network effect. The benefits associated with being in the winning network generally increase with the strength of the network effect. Existing users of the telephone network receive more benefit from the addition of a million people to that network than existing users of Web browser software would receive from the proportional addition of more users of the software. The ratio of inherent to network benefits is relevant here: the higher the inherent benefit, the less power network theory will have to predict consumer behavior. For both of these reasons, strong networks have a stronger lock-in effect, are more durable, and take greater force to displace than weak ones.

With respect to actual or virtual networks, these facts alone do not unambiguously imply any particular legal conclusion. A strong network effect can be either good or bad, depending on the nature of the standard, the difficulty of transitioning to alternative standards, and, from a legal perspective, the effect the standard has on the goals of the principal fields of law with which it intersects. Strong networks can even be both good and bad, as where a destructive standards competition is re- 
solved in favor of a suboptimal product that nonetheless gives consumers the benefits of the network effect.

Nonetheless, we can draw some tentative conclusions about the strength of network effects. Because strong network effects tend to produce more uniform standards with more durable effects, the law should be more concerned with attempts to control or exclude others from participating in a standard if the standard is part of an actual or strong virtual network than if the battle is merely over convenience effects. At the same time, courts should be less willing to interfere with the operation of the strong standard itself, since adoption of strong network standards generally has large positive network effects.

We believe that courts should substantially discount network claims based only on evidence of positive returns to a certain level of scale. For example, we are unaware of any compelling evidence that suggests that the law should be revised to take care of the problems faced by the only owner of an exotic car in a sinall town. ${ }^{480}$

Courts should be particularly cautious in cases in which the network does not involve the standard consumer goods on which most of the economic literature has been based. One may draw analogies between telephone networks and contract terms or corporate statutes. Such analogies are not complete, however, and, as Klausner has noted, they require further study before confident conclusions can be drawn. If an analytical approach leads to a finding of intra-firm network effects, for example, it is likely that some other economic force related to productive efficiency is actually at work. To take another example, many markets subject to network effects involve the combination of distinct vertically-related products, such as VCRs or software, to satisfy consumer needs. Corporate governance terms themselves, however, are the products of vertical relationships among contract terms, firms, and intermediaries, with potential network effects operating at each level. These and the numerous other variables discussed above suggest that courts and legislatures should tread especially lightly in adapting network theory to fields in which the relevant payoff relationships are not well understood.

480. If I am the only person who owns a Range Rover in a town, it may not make any sense for a mechanic to open a garage devoted to servicing Range Rovers. The cost of opening the garage and training a mechanic will not be covered by the minimal business I am likely to generate. On the other hand, if 100 people in the town own Range Rovers, specializing in Range Rovers may make economic sense. One might think of this as a "network effect"- the other 99 people who bought Range Rovers collectively conferred a benefit on existing Range Rover owners (i.e., me). But this is not a network effect, precisely because it is tied directly to the economies of providing service, and docs not extend over the range of market demand. The marginal customer who warrants the addition of a garage has benefited all the existing customers, but other marginal added Range Rover customers do not necessarily confer any such benefit. Indeed, customers beyond 100 may have a negative effect on existing owners, causing the garage to be too busy. 


\section{B. Evidence Supporting Network Effects}

Evaluating a claiin of network effects involves not only an inquiry into the type of network effect at issue, but also a factual determination of whether such a network effect actually exists. In part, this determination does not differ from the evaluation of any legal claim: the factfinder must review the evidence to determine whether the assertion that a network effect exists is real or illusory. This evidence will undoubtedly be economic in nature, and proffered evidence may in fact consist of economic expert testimony, or even anecdotes. Courts have dealt with such economic evidence in other contexts, and the same general principles apply here. However, economic evidence contains traps for the unwary. The recent challenges to the once widely-accepted QWERTY story ${ }^{481}$ offer some reason for caution: economic explanations for historical events do not come free from doubt, and there is always a danger that particular circumstances will be misinterpreted as involving network effects. In addition, there are some more general pitfalls associated with factual claims that a market is characterized by network effects. Many economic phenomena may resemble network effects at first glance. In this Section, we identify four such phenomena that should not be mistaken for network effects.

First, general positive externalities often resemble network effects. In economic terms, a positive externality exists whenever a private action confers uncoinpensated benefits on third parties. Education exhibits certain positive externalities; while the student obtams some benefit from her education, the full social benefit of her education is more diffuse, including the effects of her productivity, information she passes on to others, the fact that she is less likely to commit crimes, and so on. Because she cannot capture or charge for these benefits, the student's private return to education is less than the social return, and she will not "consume" enough education unless soine steps are taken to compensate for this externality. Education is not a network effect, however. Whatever social benefits one's education confers are not a function of the number of other people being educated.

Some general positive externalities may at first glance appear to be network effects. For example, building an attractive destination store in

481. One of the paradigmatic examples of the pernicious effects of networks was the QWERTY typewriter keyboard. According to the classic story, the inferior QWERTY keyboard layout has dominated the market for over a century because of network-related lock-in: no one wants to be the first to switch to an alternate keyboard. See, e.g., Paul A. David, Clio and the Economics of QWERTY, 75:2 AM. EcoN REv. 332 (1985). In several articles, Liebowitz \& Margolis have cast doubt on the historical basis of the claim that the alternate Dvorak keyboard is in fact better. See S.J. Liebowitz \& Stephen E. Margolis, The Fable of the Keys, 33 J.L. \& EcoN 1 (1990); Liebowitz \& Margolis, Uncommon Tragedy, supra note 5, at 133. For efforts to rehabilitate the Dvorak story, see Jared Diamond, The Curse of QWERTY, DISCOVER, Apr. 1997, at 34. 
a shopping mall confers benefits on other stores in that mall because it brings more customers in to shop. This is a positive externality, but not a network effect. While shop owners would all benefit from increased quality stores in the mall up to a certain point, the benefit does not extend across the entire range of market demand. Stores im competition with the new ones may lose rather than gain. To the extent the mall is fixed in size, new stores may displace, rather than coexist with, existing stores. Even assuming no external constraint on mall size, the mall may have a maximum efficient size-a mall which is too big for consumers to handle easily will not confer benefits on its members.

This leads us to a second, related economic phenomenon sometimes confused for network effects: economies of scale. Econormes of scale exist when the cost of production per unit declines as the number of units produced increases. ${ }^{482}$ Economies of scale frequently occur in industries characterized by high fixed costs. ${ }^{483}$ If it costs $\$ 100$ million to build a new steel factory, its owner will want to use that factory for more than producing a single steel bar. The average total cost of producing each new bar may decline up to a certain point, as fixed costs are amortized. Economies of scale resemble network effects because both phenomena exhibit increasing returns over significant portions of the demand curve. The key difference lies in the source of the returns. In actual network markets, each additional consumer adds value to the network either by increasing the number of people who can be reached through the network or by mcreasing the convenience associated with using the standard. For industries displaying economies of scale, by contrast, the effect is on the supply rather than the demand side. The increased value comes from the increased productivity of capital investments, regardless of the manner $m$ which consumers use the good in question.

These scale economies are distinct from network effects. Microsoft enjoys very large economies of scale im producing its software because its fixed costs are quite high and its variable costs quite low. ${ }^{484}$ If Microsoft's products could be used only by imdividual consumers for individual purposes - if they did not interoperate either with like goods or with compatible goods-Microsoft would still enjoy significant economies of scale simply by virtue of this cost structure. The interop-

482. See PINDYCK \& Rubinfeld, supra note 10 , at 217.

483. See generally BlaIR \& KASERMAN, supra note 88, at 94-95. But cf. HovenKamp, supra note 52, § 6.3, at 247 (1994) (courts can't effectively determine when scale economies exist).

484. The "marginal cost" of a new copy of Microsoft Windows is the cost of the disk (a few cents), the labor required to copy it (essentially none), and the cost of the manuals, packaging, and distribution of the box itself to consumers (by far the largest portion). Software distributed on the Internet has essentially no marginal cost, as it can be downloaded by consumers on their own time, albeit with some commitment of computer resources by the supplier. 
erable nature of its products adds value in part made possible by the same consumer demand that facilitates scale economies-both the ability to share files and the size of an aftermarket of application programs will mcrease with demand-but the value created by the network benefits of interoperability is distinct from the value created by declining marginal costs of production. To distinguish a genuine network phenomenon from traditional economies of scale, a court should seek to ascertain the portion of a firm's returns generated by the cost structure of the industry in which it operates-economies that end at the point the product is shipped-and the portion generated by the manner in which consumers use or seek to use the product-returns generated by the consumers themselves or perhaps by other firms making complementary goods, and which begin only after the product is shipped.

Classical economic theory presumes that economies of scale at some point become diseconomies of scale, producing the classic U-shaped cost curve. ${ }^{485}$ This assumption will not always hold true, however. Classical theory treats markets in which returns increase (marginal costs fall) over the entire range of market demand as instances of natural monopoly, in which efficiency dictates that a single firm serve the entire industry. In such cases, additional consumers in the industry benefit existing consumers by amortizing a greater share of the fixed cost. ${ }^{486}$ Some of these "natural monopolies" do indeed show up in the areas we have been discussing, such as telephony. ${ }^{487}$ But the scale economies in telephony are distinguishable from the network effects. It may be efficient for a single firm to build the local telephone distribution network for a city, ${ }^{488}$ but that firm will not necessarily be the most efficient supplier of telephone wiring worldwide. Further, once the wire is installed, many different companies might compete in providing telephone switching services in the city. And different cities may efficiently hire different firms to provide their telephone wiring and switching. If economies of scale were all there was to the telephone industry, we would expect to see numerous competitors (and no government regulation). But because of network effects, each of these competitors must link to the same global telephone network in order for consumers to maximize the value they get from the network. Different companies can

485. See Walter Nicholson intermediate Mrcroeconomics AND its APLLICATIONS 244 (3d ed. 1983).

486. On this phenomenon, see Lemley, Internet Standardization, supra note 46, at 1054-55.

487. See supra notes 288-307 and accompanying text.

488. Even this assumption has been challenged of late, as new technologies such as cable and wireless service seek to compete with the existing twisted-pair telephone wire. See generally Thomas J Duesterberg \& Kenneth Gordon, Competition and Deregulation in TELECOMMUNICATIONS (1997). 
build the network-economies of scale do not prevent that-but they cannot build different networks.

The distinction between economies of scale and network effects may have a significant effect on market structure. In part, it is important because network effects are significantly more limited than economies of scale. Those who are unclear on the distinction occasionally suggest that network effects are or will be ubiquitous, even in standard products markets. ${ }^{489}$

Third, certain aspects of "path dependence" resemble network effects. Path dependence refers to the inherent tendency of history to influence present decision-making. Mark Roe cites as a paradigmatic example the construction of a road that is not straight for reasons that were once important but are today irrelevant. As the road develops over time, the history of the road influences (albeit unconsciously) decisions about how and where to construct new buildings. ${ }^{490}$ Path dependence may take the form of rational economic decision-making-it costs less now to repave the existing road than to move it altogether-or of a failure to uuderstand sunk costs. In the latter case, society may not take a rational action because it feels bound by the past. ${ }^{491}$

The concepts of network effects and path dependence obviously overlap. Path dependence resembles network theory because both tell stories about "lock-in" to existing standards. Networks will virtually always take shape over time; indeed the term "installed base" is inherently temporal. The types of externalities potentially created by networks-such as tipping or lock-in externalities-also will generally appear only over time. Nonetheless, courts should distinguish between purely historical lock-in effects that exist without regard to adoption decisions, other than the instant consumer's earlier choices, and lock-in effects which stem from the demand function of others. One way to do this is to ask what would happen if there were no history in a market, so that historical factors were rendered irrelevant. The road driven by path

489. The most notable example is Kevin Kelly, New Rules for the New Economy, WIRED, Sept. 1997, at 140, 143.

In the future, cotton shirts, bottles of vitamins, chain saws, and the rest of the industrial objects in the world will also obey the law of plenitude as the cost of producing an additional copy of them falls steeply, while the value of the network that invents, manufactures, and distributes them increases.

Kelly is wrong. In the first place, we doubt that a "network" of manufacturers in this sense is a meaningful economic concept. Even if it were, chain saws simply do not exhibit demand-side economies of scale. We would be quite suprised to see chain saws given away in the near future by companies hoping to somehow reap an advantage from having more free chain saws loose in the world. $C$. id. at 188 ("the extension of this logic says that the most valuable things of all should be those that are given away").

490. See Mark J. Roe, Chaos and Evolution in Law and Economics, 109 HARv. L. Rev. 641, 64344 (1996).

491. See id. at $651-52$. 
dependence might not end up in the same place, but telephone networks would still tend to converge on a single standard. ${ }^{492}$

Nor should network theory be confused with other models of collective behavior. David Hirshleifer describes behavioral "payoff interactions" in terms analogous to network effects and includes the payoff interaction model as one of a group of behavioral models that includes social norm theory and herd behavior. ${ }^{493}$ Hirshleifer rightly distinguishes among the theories, noting, for example, that theories of herd behavior are based on informational interactions among consumers while what we here call network theory is based on positive utility payoffs. The differences are important: at least where only a small amount of information is available, herd behavior models predict rapid consumer adoption of products or behaviors in faddish bnt brittle "cascades" that may be broken through the introduction of new information, as opposed to the lock-in concern traditionally associated with the payoff interactions of network theory ${ }_{4} 94$

Finally, one might wrongly assume that exclnsionary groups necessarily exhibit network effects. Certainly various non-network groups derive value from membership that increases with the number of members-political and social organizations, for example. ${ }^{495}$ However, not all such groups truly exhibit network effects. Economic literature suggests that a relatively sinall group of committed people may be more effective in politics than a larger group of less committed people. ${ }^{496}$ Further, at least some snch groups obtain value precisely from limiting membership, either to preserve their presumed exclusivity or to distinguish themselves from "everyone else." A political party with 100 million members is more powerful than one with 100 members, but a political "party" whose members include everyone in the conntry has no power at all in an important sense. Groups that derive value from excluding rather than including others are not good examples of network effects. Indeed, they are in some sense the opposite of a true network.

492. Path dependence-rather than network effects-may explain the persistence of inartful language in standard form contracts that Hill observes. HILL, supra note 375 , at 3.

493. David Hirshleifer, The Blind Leading the Blind: Social Influence, Fads, and Informational Cascades, in Mariano Tammasi \& Kathryn Ierulli, The New Economics of Human BeHAvior 192 (1995) ("A second class of theories is based on payoff interactions, in which one person's action directly increases the benefit to someone else of doing the same thing.").

494. See id. at 191-93.

495. Cartels are another. Cartel members benefit from the participation of their competitors in the cartel, since the greater the percentage of competitors who participate, the less vulnerable the cartel will be to cheating. However, this is not a pure network effect, since cartel members do not actually benefit from the addition of new competitors to the market, and indeed would prefer to limit the total number of competitors.

496. See, e.g., Mancur Olson, The Logic of Collective Action (1971); McGowan \& Lemley, supra note 161, at 324-25. 
Of course, for some purposes, a court may not care whether a claimed economic effect really is a network effect or not. If the court seeks to internalize a positive externality, it might choose to do so regardless of whether the externality is a network effect. But we think it important to distinguish these classes of economic phenomena. In some mstances, the law treats network economics in a strikingly different manner from related effects, like economies of scale. Courts should at a minimum strive accurately to identify the issues confronting them before taking (or abstaining from) legal action on the basis of a claimed economic effect.

\section{Ameliorative Effects}

Courts evaluating claims based on network effects should also be cognizant of three factors that serve to temper the strength of network effects: nonexclusivity, open standards, and the presence of intermediaries to facilitate transition between standards. Certain network markets are less vulnerable to lock-in than others. In particular, nonexclusive standards may allow consumers to gain the benefits of widespread adoption without foregoing the benefits of either competition or improved technical standards. For example, ATM networks are largely nonexclusive. There is no technical reason why a bank cannot link its ATMs to every ATM network, ${ }^{497}$ giving the bank's consumers the maximum network benefit and (not incidentally) making it possible for network providers to compete with each other over the long term. ${ }^{498}$ Nonexclusivity partially counteracts the potential lock-in effects of even a strong network, simce consumers do not have to give up one standard to embrace another. They do have to embrace the leading standard, however, meaning that the owner of that standard has potential market power.

For similar reasons, the open nature of a network standard may ameliorat costs attributable to the strength of that standard. ${ }^{499}$ Even if network effects force all consumers to migrate to a single product stan-

497. Indeed, most banks are linked to multiple ATM networks, although not to all of them.

498. Where consumers can belong to multiple overlapping networks, the switching costs of moving to a new network approach zero. This has significant implications for the behavior of the networks themselves. If networks are to attract members, they must competc on some ground other than simply the number of members. A network that had the most members, but which offered unattractive terms compared to other networks, could easily find itself replaced as consumers signed up en masse with its more attractive competitor, and then found that they no longer needed the first network.

499. Open standards can exist for a variety of reasons: because the market drives "owners" of standards to open them up, as was the case with the IBM PC and the VHS VCR; because it is not techincally possible to prevent others from adopting the standard (think of the two-prong electric plug or the design of cars optimized for driving on the right side of the road); or because the law explicitly allows access to a standard. 
dard, they (and society) will benefit if numerous companies compete to provide products compatible with that standard. Not only will the price of the product standard fall, and the adoptions of the standard correspondingly rise toward the optimal level, ${ }^{500}$ but competition within a standard should spur technological innovation toward improved standards, and particularly toward improvements that can be reached by migration, rather than by throwing out the old standard entirely. Similarly, intermediaries may facilitate transition among standards, as in the case of investment banks and event-risk debt. The same dynamic may diminish the significance of network effects in other markets as well. Some early software programs, for example, were explicitly designed to serve as bridges between incompatible application programs, translating files between the two.

These ameliorative effects have two important implications for courts considering a network effects claim. First, both nonexclusivity and open standards reduce the lock-in effects otherwise exhibited by strong networks. Further, open standards generally reduce the economic distortions associated with monopoly ownership of standards. The presence of one or more of these factors therefore lessens the need for judicial action to "correct" or alter the effect of the network inarket. In contrast, markets with exclusive or closed standards, or inarkets in which intermediaries cannot facilitate transitions for soine reason, are inore likely to require judicial intervention. In effect, these teinpering factors combine with the nature of the claimed network effect to produce a more nuanced view of the "strength" of the network effect. 501

Second, courts should evaluate clains for judicial relief in part based on the effect they have on the openness of network standards. Particularly with respect to strong network effects, courts should favor legal solutions that open standards to competition, either through nonexclusivity or through group participation in a single standard. Such solutions may not always be appropriate, nor should they always be judicially compelled. Courts should remain cognizant of the legal environment in which they operate: for example, a court's declaration that network standards can never be "owned" as intellectual property rights would likely have significant negative effects on incentives to invent,

500. In a network market, each new consumer benefits all existing consumers. This benefit takes the form of an uncompensated positive externality-there is generally no effective way for existing consumers to pay back the additional value they receive. Thus, at the marginal private cost to the supplier, not enough new consumers will enter the market absent a coordinating mechanism. For at least a portion of the extent of strong networks, the socially optimal price for new consumers will likely be below the marginal cost of serving them, reflecting the benefits their entry confers upon others.

501. See McGowan, supra note 11, at 847-48 (suggesting that network effects should not be cause for antitrust concern in circumstances where competitors have legal access to the standard). 
and perhaps on intellectual property doctrine in general. Nonetheless, courts and legislatures should take account of these ameliorative effects in appropriate cases when setting legal policy within this broader framework.

\section{Significance of the Network Effect in the Industry}

Even once a court has established that a network effect operates in a market, determined its nature and strength, and evaluated any ameliorative effects, it should also assess the significance of the network effect in the context of the market in which it occurs. Consumers make purchasing decisions within markets that have product-space, geographicspace, and temporal boundaries. Networks exert their strongest effects when they coincide with or are broader than consumer markets. This is the case with telephones, for example. Consumers buy both local and long-distance telephone service. Regardless of where they live, however, or what kind of telephone service they seek, they want their telephones connected to the single worldwide telephone network. The network effect in this market encompasses the consuiner market (and indeed a number of different geographic markets linked together by the network itself).

By contrast, not all network effects fill the product-space of a consumer's market choice. Consider automobile fuel doors. Automotive designers cannot seem to agree where they belong. In different model cars, the fuel door might be on the driver's side, the passenger's side, or the back of the car. Drivers of borrowed or rental cars must either invest time in learning the location of their fuel door, or end up parking on the wrong side of a gas station island. One can make a plausible argument that this is a convenience-related network effect and that the market exhibits suboptimal heterogeneity (foregone efficiencies) of gasdoor location. Even if this constitutes a network effect, though, it does not drive the market to standardization for the simple reason , that it is extremely unlikely ever to influence a purchasing decision in a real market. Consumers do not buy fuel doors; they buy cars, and the fuel door contributes only trivially if at all to that purchasing decision. A similar effect may render networks of contract terms insignificant-a relatively unimportant single term in a form contract will not affect the decisions of the contracting parties to adopt the form. Network effects may exist in these component markets, but they are unlikely to be significant from an overall market perspective.

Of course, numerous network effects will fall between these two extremes. Networks may occupy only certain product market segments, or only certain geographic areas. As a general rule, the significance of network effects positively correlates with their size in relation to product 
and geographic markets. Even a "strong" network effect involving automobile fuel doors is unlikely to be terribly important because it won't affect purchasing decisions at the full product level and therefore will not determine market structure. By contrast, $\mathrm{m}$ industries in which the network defines the market, even weaker, convenience-related effects can play a significant role in determining market structure.

\section{E. Importance of Existing Legal Rules}

Network effects (strong or weak, big or small) do not occur in a vacuum. They are the product of economic, physical, and legal constraints that make up the market environment. ${ }^{502}$ Courts evaluating legal claims of network effects should place particular emphasis on one of those sets of constraints-the legal rules that contribute to network effects. Where the law contributes to, or indeed causes, the market conditions that create network economic effects, courts should pay special attention to the policies behind such legal rules.

In many cases, of course, law is unrelated to or at most entirely incidental to network effects. Even if one accepts the story of the QWERTY keyboard, for example, the standardization of that keyboard occurred entirely without the intervention of the law. No law required people to use the QWERTY keyboard, or even the same keyboard everyone else used. Nor did any legal rule (such as an intellectual property right) restrain the production of keyboard formats by any private company. The law does not bind courts either to accept these alleged effects or attempt to change them. We characterize this as a regime in which the legal constraints on judicial action are low, but the power of courts to act may be low as well.

Law may play a more significant role in network effects involving Klausner's networks of contracts. ${ }^{503}$ In theory, judicial decisions may increase the value of corporate goveruance terms by clarifying their meaning, and thus reducing the risk associated with using the term. To the generally modest extent that interpretive network effects may exist, courts function as the principal interpreters, and possess a unique power to affect the strength of the network. At the same time, legal constraints in the realm of contract exceed those in the QWERTY context: judicial action regarding standard contract terms influences the development of contract law in general and is subject to the general limits of statutory authorization (or at least the threat of later legislative repudiation). ${ }^{504}$ To

502. On this interrelationship, see Lessig, Constitution in Cyberspace, supra note 316, at 870.

503. See Klausner, supra note 5, at 764-65; supra notes $463-479$ and accompanying text for a detailed discussion.

504. The Delaware Supreme Court's decision in Smith v. Van Gorkum, 488 A.2d 858 (Del.

1985), for example, prompted the Delaware legislature to supplement the protections from liability 
maximize clarity, courts should adhere to precedent to the extent possible and fully articulate the reasons for their decisions, especially when they modify the law. ${ }^{505}$ In interpreting tests such as "reasonable in relation to the threat posed," courts should do their best to identify both the variables they deem important to a given decision and limitations on their rulings. Klausner's regime is thus one of moderate judicial power, but moderate constraint as well. 506

Intellectual property law demonstrates an even greater relationship between legal doctrine and network effects. In a fundamental sense, the structure of intellectual property law determines the strength of network effects in a number of markets. Certainly, proprietary ownership of de facto standards in the computer industry is an artifact of imtellectual property law. Without intellectual property law, Microsoft would not have a monopoly on PC operating systems, because every program they released would be rapidly and widely copied. This would solve many of the problems associated with network effects: competition to sell the program would drive the price toward marginal cost (near \$0), expanding the number of people who used the standard software toward the efficient level. Further, the ability of numerous competitors to improve on the Microsoft operating system with impunity would encourage migration within the standard to newer versions. Of course, there are good policy reasons to support continued intellectual property protection for software, even when it is a de facto standard. The existence of intellectual property protection is based on the concern that, without a means of appropriating at least some inarket power, no one will have an incentive to create new software. ${ }^{507}$ Intellectual property protection represents a considered judgment that, at least on average, the social value

available to corporate officers and directors. Forty-one other states soon followed suit. See GrLson \& BLACK, supra note 407, at 1057.

505. Kahan and Klausner also suggest that courts should adopt uniform interpretation of boilerplate terms and give weight to the "legislative history" of the contractual equivalent of standard-setting organizations, such as the American Bar Foundation's Commentaries to its Model Debenture Indenture. See Kahan \& Klausner, Standardization, supra note 60, at 762-66. These points have been recognized by several courts, and we agree with them. See, e.g., Leverso v. Southtrust Bank of Al., Nat'l Assoc., 18 F.3d 1527, 1534 (11th Cir. 1994) ("The mcaning of boilerplate provisions is a matter of law and must be given a consistent, uniform interpretation ...."); Sharon Steel Corp. v. Chase Manhattan Bank, 691 F.2d 1039, 1048 (2d Cir. 1982) (holding boilerplate provision, as distinct from contractual provisions, "must be given a consistent, uniform interpretation").

506. Network theory does highlight the importance of judicial consideration of potential differences in the economic world in which different firms operate, and the differing market forces they face. Such an evaluation, we hope, would avoid transforming a general term that might otherwise provide room for tailoring into a majoritarian default simply by virtue of judicial opinions that fail to account for differences among firms.

507. See Lemley \& O'Brien, supra note 36, at 830-31; McGowan, supra note 11, at 775-77; Pamela Samuelson et al., A Manifesto Concerning the Legal Protection of Computer Programs, 94 Colum. L. Rev. 2308 (1994). 
contributed by innovation, spurred by the incentive of intellectual property, outweighs the competitive harm caused by proprietary ownership of those innovations.

That Microsoft's proprietary network standard depends on intellectual property law ineans that the law has more power over the network effects in this regime. Of course, significant legal constraints operate here as well. Intellectual property law is a creature of statute, and the statutes do not generally permit the courts to withdraw intellectual property protection on an as-needed basis. Further, some recent "takings" cases suggest that the Constitution may limit judicial discretion to withdraw intellectual property protection. ${ }^{508}$ Nonetheless, intellectual property law does retain judicial flexibility in a number of areas, notably where the scope of intellectual property rights has not been settled or where copyright's fair use doctrine allows tailoring of protection to the circumstances. This flexibility means that courts can sometimes act within the confines of the law to counter negative network effects, for example by favoring open standards or coinpelling interoperability. Thus, we would characterize the intellectual property regime as one of high power and moderate constraint.

Finally, legal rules themselves sometines compel the choice of a standard. One example is the U.S. rule that autos must drive on the right side of the road. This standard results directly from legal action and enforcement. ${ }^{509}$ Other examples include those limited cases in which the government itself mandates a choice between competing private network standards, as in the case of high-definition television. ${ }^{510}$ Here, the law wields a high degree of power over the standard; whether a product may be sold at all may depend on what the law says. However, the legal con-

508. See, e.g., Ruckelshaus v. Monsanto Co., 467 U.S. 986, 1016 (1984) (government statute compelling disclosure of corporation's product ingredients was a taking that required compensation). The Supreme Court's 1996 decision in Seminole Tribe stripped Congress of the power to hold states liable for patent and copyright infringement under the Commerce Clause. See Seminole Tribe v. Florida, 116 S. C. 1114, 1127 (1996). However, in the wake of Seminole Tribe, some courts have held that patents and copyrights are "property" within the meaning of the Fourteenth Amendment, and thus that Congress has the power to legislate regarding them in a way that is binding on states. See, e.g., Genentech, Inc. v. Regents of the Univ. of Cal., 939 F. Supp. 639, 643 (S.D. Ind. 1996); College Sav. Bank v. Forida Prepaid Postsecondary Educ. Expense Bd., 948 F. Supp. 400, 422-23 (D.N.J. 1996). If this approach is upheld, it may logically open the door to the argument that any government interference with intellectual property rights is a "taking" of that property. For discussions of Seminole Tribe that focus on intellectual property, see Christina Bohannon \& Thomas F. Cotter, When the State Steals Ideas: Is the Abrogation of State Sovereign Immunity from Federal Infringement Claims Constitutional in Light of Seminole Tribe? (Working Paper 1998); Paul J. Heald \& Michael L. Wells, MISAPPROPRIATION OF INTELECTUAL PROPERTY BY STATE AND MUNICIPAL GOVERNMENTS: REMEDIES AND IMMUNITES (Working Paper, 1998).

509. Of course, the standard might have arisen anyway as a result of market forces.

5I0. See supra notes 272-275 and accompanying text (discussing government standard setting in HDTV). 
straints on judicial action are normally also high, unless the legal rule has been established by or delegated to the judiciary.

Judicial power over network effects, like the size and significance of those effects, is merely one factor affecting the propriety of legal action to deal with network effects. In some circumstances, like the elimination of intellectual property rights, judicial action, though possible, may not be appropriate for policy reasons. In others, judicial action may be a part of the effect itself. This insight merely reinforces the importance of clarity in thinking through cases and drafting opinions. In addition to their ability to act and the likely efficacy of their action, courts must also consider the nature of the legal action that must be taken. We consider this problem in the next Section.

\section{F. Nature of the Relief Sought}

Finally, the nature of the judicial relief sought as a result of network effects will play a significant role in how courts evaluate and treat such effects. The judiciary should fashion relief in light of the following considerations.

First, the mere existence of network effects is not outcomedeterminative, as their presence could be offered either to excuse conduct or to penalize it. ${ }^{511}$ As a general matter, network-effects-as-excuse arguments require less intrusive judicial action than those that would attempt to punish or undo network effects. Excuse-based arguments do not require courts to attempt to alter or counteract existing economic effects, merely to acknowledge their existence. ${ }^{512}$ In at least one sense, therefore, excuse-based arguments raise fewer problems than arguments requiring courts to take more affirmative action. Even here, though, the problem of remedy poses complex questions, because the same network argument may be used to seek an array of different remedies. While courts might (and likely should) consider network effects a good reason not to attempt to fragment a standard (one level of exculpation), the sheer presence of such effects will not necessarily weigh against the use of alternative legal rules to open the standard or, from a legislative perspective, to regulate the prices that may be charged for its use. Ultimately, none of these alternatives may be desirable, ${ }^{513}$ but the manner and degree to which network theory serves as an excuse will differ with respect to each of them.

511. See, for example, the arguments in the antitnust context. See supra notes $68-189$ and accompanying text.

512. Of course, excuse-based arguments may require greater alteration of legal rules in any given case, depending on the way in which those rules are written.

513. And we can safely say that calls are made for such remedies more often than they are actually warranted. 
Second, even where the totality of circumstances requires some affirmative action, the nature of the relationship between the network effects and existing legal rules may hamper, or at least complicate, that action. In certain cases, where the network effects result from existing governmental support, withdrawing or conditioning that support may alter those effects. Intellectual property presents such a (comparatively) "easy" case. Even if withdrawing intellectual property entitlements to network standards proves impossible or undesirable, ${ }^{514}$ courts may effectively condition those entitlemeuts (for example, by permitting reverse engineering or requiring group standards to remain open) im a way that ameliorates their negative effects. By contrast, a court will encounter much more difficulty attempting to "undo" network effects established by economic forces, as with some proposed antitrust solutions to network-based problems. ${ }^{515}$ Such a remedy, where a court attempts to remake a market, not only necessarily requires more factspecific and potentially ongoing judicial involvement, but raises the potential for unintended consequences as well. ${ }^{516}$ We do not suggest that such remedial measures are never appropriate, but their intrusive nature certainly recommeuds caution.

Third, courts must consider how easily the claimed relief fits within the existing body of legal doctrine at issue. This is, in part, a matter of judicial experience in taking economic circumstances into account. Antitrust law has more thoroughly integrated economic theory and evidence most other fields. ${ }^{517}$ Antitrust precedeut therefore provides courts with a relatively better foundation for integrating economic variables into the law. Similarly, legal arguments based on network effects will fare better if they can point to analogous use of uetwork-based arguments in related fields.

Courts inust also consider the flexibility of particular legal doctrines. Network effects often represent exceptional cases in the law, and accommodating them in all disciplines may have a distorting effect on the legal rule in "normal" cases. This is particularly true where the law adopts an intentionally inflexible rule in an effort to reduce uncertainty ${ }^{518}$ In certain circumstances, taking a long-term view of a particu-

514. See supra notes 232-235 and accompanying text (discussing the problems with such an approach).

515. See supra notes 192-218 and 247-267 and accompanying text (discussing such approaches).

516. Strict antitrust limitations on horizontal and vertical mergers in the 1950s and 1960s, for example, may have contributed to the conglomerate merger phenomenon, and thus the inefficiencies likely associated with such firms. See GILsoN \& BLACK, supra note 407, at 329, 339-46.

517. See Herbert Hovenkamp, The Areeda-Tumer Treatise in Antitrust Analysis, 41 ANTITRUST Bull. 815, 821 (1996) (describing antitrust as "an extreme case of 'applied' economics").

518. See id. (arguing that economic analysis in antitrust should sacrifice some accuracy for the sake of simplicity, because "the more accurate measure is likely to invite complexity and, as a result, error"). 
lar body of law may cause courts to ignore network effects that operate in only a few cases in order to avoid opening the floodgates to a variety of frivolous claims. ${ }^{519}$ This argument can be taken too far: legal rules so inflexible that they do not reflect reality are generally undesirable. Bnt, as a general matter, the less a particular legal doctrine must adapt to take account of network effects, the better for all concerned.

This point brings up a final, related one: the desirability of minimizing distortion applies among legal disciplines as well as within them. Courts should, where possible, eliminate a pernicious network effect by applying an existing legal doctrine, or fashioning a narrowly focused holding, rather than making wholesale adaptations to a different legal discipline. We refer to this as the principle of "minimal invasiveness." This principle has important implications for judicial choice of remedy once a problematic network effect has been identified. Generally, courts dealing with a network-related problem on a narrow, fact-specific basis will create fewer distortions in cases not involving network effects. ${ }^{520}$

For example, the claim that something must be done about Microsoft's economic power may potentially implicate antitrust, copyright, or contract law. If a court concluded that Microsoft had obtained its position as the standard operating system by announcing an open architecture in order to induce other firms to produce complementary software and then closed the standard, a court would then have to select the best legal tools to address the problein. Antitrust, which is keyed to economic facts such as market share, provides relatively blunt remedies. Copyright, which has the analytical tools that more closely fit the economic facts behind Microsoft's success, would provide a relatively narrower approach, and would avoid potential unintended consequences from an opinion keyed simply to market share. Even within copyright, as the First Circuit's opinion in Lotus v. Borland demonstrates, a court could choose either to address the copyrightability of a type of software, or to attempt to fashion more particularized remedies under the fair use doctrine..$^{221}$

519. Various commentators have made such arguments in antitrust law, contending that legal conclusions such as the essential facilities doctrine or the intrabrand market acknowledged in Eastman Kodak Co. v. Image Technical Servs., 504 U.S. 451, 501 (1992), even if technically correct, lead to enormous numbers of unsupported claims. See, e.g., Areeda, supra note 173, at 841; McGowan, supra note 11, at 80406; Carl Shapiro, Aftermarkets and Consumer Welfare: Making Sense of Kodak, 63 ANTITRUST L. J. 483, 485 (1995).

520. Judge Easterbrook has argued that in a complex field like antitrust, legislative rules are more likely than judicial decisions to get it right. See Frank Easterbrook, Ignorance and Antitrust, in Thomas M. Jorde \& David J. TeECe, Antitrust, Innovation and Competitiveness 119, 12329 (1992). We are not entirely persuaded. Cetainly, legislative rules might sometimes be tailored enough to be thought "minimally invasive"-consider Klausner's menus of contracts, for example. But by and large, legislative solutions are both more difficult and more general than judicial decisions.

521. See Lotus Dev. Corp. v. Borland Int'1, Inc. 49 F.3d 807, 821-22 (1st Cir. 1995), aff'd 516 U.S. 233 (1996), (Boudin, J., concurring) (exploring some of these choices); Lemley, supra note 200, 
Still, although one could conceive of a fair use opinion tied in some way to the original pronouncement that created the problem in the first place, it is a bit of a stretch. A court might instead look to contract law or estoppel, seeking to key the legal obligations imposed by the court to the original pronouncements that induced third-party investment in compatible goods. Of the available approaches, this last one would avoid potential negative consequences associated with a broad antitrust ruling limiting intellectual property rights, avoid problems associated with excluding certain portions of a product from copyright protection, and allow firms to choose ex ante the level of ongoing obligations they would assume. Such a rule might also have a beneficial information-forcing function: if a firm producing a computer operating system secretly imtended to leave its architecture open only long enough to develop the critical mass of application programs necessary to help it win the standards competition for operating systems, then it would have to reserve the right to close its architecture in the future, potentially prompting third-party firms to bargain for rights they might not otherwise think they needed. ${ }^{522}$

Thus, we suggest that, in particular cases, existing doctrines of contract law or equitable estoppel may serve as a better mechanism to compel open access to a standard-setting organization than the essential facilities doctrine in antitrust; ${ }^{523}$ that tailored applications of the fair use doctrine in copyright are a better way to alleviate problems caused by private ownership of network standards than revocation of the copyright itself; ${ }^{524}$ and that compelling equal access to a network standard on nondiscriminatory terms is normally preferable to government standardsetting. ${ }^{525}$ Further, some network problems may correct themselves, either because the market itself will gravitate toward an open standard, or because the ability of consumers to use multiple standards will defeat attempts at exclusivity. ${ }^{526}$ In these latter cases, the "minimally invasive" alternative requires courts to do nothing at all, except ensure that no one deliberately impedes the market process.

at 1079-81 (suggesting that Lotus should have been decided on more narrow grounds than in fact it was); McGowan, supra note 11, at 848 n.310 (suggesting Judge Boudin's fair use approach was preferable to the majority's).

522. See McGowan, supra note 11 , at $836-41$ (elaborating on this approach). We also discuss it further in Lemley \& McGowan, supra note 105.

523. Such doctrines will not work in all cases, however. For some reasons why, see Lemley, Intemet Standardization, supra note 46, at 1090-92.

524. See supra notes 230-246 and accompanying text (discussing these alternatives).

525. See supra notes 274-285 and accompanying text (discussing these alternatives).

526. Matutes and Regibeau demonstrate that under certain market conditions, notably those involving consumer assembly of systems from component products, the equilibrium state involves full compatibility. See Carmen Matutes \& Pierre Regibeau, "Mix and Match": Product Compatibility without Network Externalities, 19 RAND J. Econ. 221 (1988). To the extent this is true, legal efforts to force compatibility in such markets may prove unnecessary. 


\section{CONCLUSION}

Network effects theory provides an important example of the process by which the law learns from and adapts to theories from other disciplines. Network theories are potentially important to many legal fields and, because in some circumstances they challenge the classical economic presumption of declining returns to scale, may have far-reaching consequences for the development of the law. The process of adaptation will be difficult, however, because of the variety of arguments network theory can support and the differing, indeed opposing, conclusions to which such arguments lead. Courts confronted with arguments based on network theories should first ascertain the nature of the claim asserted. We believe network arguments can best be categorized along a continuum, with actual networks-in effect communications systems-the strongest, and virtual networks-frequently mvolving interfaces between vertically related goods-providing a range of examples of differing strength. At the other end of the continuum are a variety of phenomena in which provision of a good or service positively relates to some level of scale, but im which the scale economies themselves create the value rather than interactions among users of the good.

After assessing the nature of the claim, courts should examine the market evidence advanced in support of the claim. In doing so, courts must be careful not to infer the presence of network effects solely from a coincidence of a large number of consumers of a particular good and significant economies of scale. Courts should focus on whether factors usually associated with scale economies, most particularly declining average costs, or interactions among users of the good, which provides stronger evidence of a potential network effect, generate the returns at issue. They should also look for indications that the network effect does (or does not) play a significant role in purchasing decisions, and identify what if any probleuns this causes.

If the network effects are real, significant, and appear to diminish social welfare, and if they cannot be solved within the market, courts should then consider which legal doctrines offer the appropriate remedy. To the extent precedent permits, they should seek remedies from within the field of law that best takes into account both the nature of the conduct complained of and whatever level of network effects exist. Within that field, courts should seek to pursne the course that provides an adequate remedy with the least possible disruption to other legal doctrines.

This analysis is complex and fact-specific. Some find this a flaw, suggesting that courts require simple rules rather than complex stan- 
dards to guide their decision-making. ${ }^{527}$ We see it rather as a virtue. Whatever the value of bright-line rules in circumstances in which courts know (or think they know) how to characterize conduct, the error costs of such categorization in network markets today are simply too great. We do not know nearly as much as we would like about how networks work and what they mean for market structure; what we do know suggests that network "effects" may have either positive or negative ramifications depending on a whole host of factors. It is sometimes efficient to give up accuracy for certainty and ease of administration. But here, the accuracy we will lose will be significant, and the gain in administrative efficiency uncertain. ${ }^{528}$

More generally, the example of network effects suggests some things about the role that economic theory (and by extension, other theories external to law) plays in the judicial enterprise. All law is purposive. Decision-makers craft the statutory and common law with some end in mind. Economic theory can generate predictions about how different legal rules will affect the state of the world and, to that extent, provide important information to the legal decision-making process. If the law wishes to induce the production of intellectual property, for example, rate of return analysis should play an important role in any sensible intellectual property regime. However, economic theory remains, or at least should remain, generally aguostic on normative matters: it cannot tell us whether encouraging the production of intellectual property is something we should wish to do. There is a difference between law and economics, an estimable discipline, and law as economics, an unrealistic construct.

527. See, e.g. Gregory Scott Crespi, Exploring the Complicationist Gambit: An Austrian Approach to the Economic Analysis of Law, 73 Notre DaMe L. Rev. 315 (1998); Gregory S. Crespi, Does the Chicago School Need to Expand Its Curriculum?, 22 L. \& Soc. INQUIRY 149, 154 (1997) (warning against the danger of overcomplicating economic analysis of law). But see Thomas S. Ulen, Professor Crespi on Chicago, 22 L. \& Soc. INQuiRY 191, 197-98 (1997) (criticizing this approach). The literature on what might he called the "rules vs. standards" debate is voluminous. See generally Isaac Ehrlich \& Richard A. Posner, An Economic Analysis of Legal Rulemaking, 3 J. LEGaL STUD. 257 (1974); Louis Kaplow, Rules versus Standards: An Economic Analysis, 42 Duke L.J. 557 (1992). Besides the obvious parameters of administrative cost and accuracy of result, more recent scholarship has suggested that adopting ambiguous standards may actually have positive effects on bargaining. See, e.g., DAN L. BURK, MUdDY Rules FOR CyBerspace (Working Paper, 1997); Ian Ayres \& Eric Talley, Solomonic Bargaining: Dividing a Legal Entitlement to Facilitate Coasean Trade, 104 Yale L.J. 1027 (1995); Jason Scott Johnston, Bargaining under Rules versus Standards, 11 JL. ECON. \& ORG. 256 (1995). cf. Gillian K. Hadfield, Judicial Competence and the Interpretation of Incomplete Contracts, 23 J. LEGAL STUD. 159, 162 (1994).

528. This approach finds support from a surprising source: law and economics icon Friedrich Hayek, who wrote that "I prefer true but imperfect knowledge... [S]eemingly simple but false theories may have grave consequences." Friedrich Hayek, The Pretense of Knowledge, in THE ESSENCE OF HAYEK 266, 272 (Chiaki Nishiyama \& Kurt Leube eds., 1984); see also Arthur Allen Leff, Economic Analysis of Law: Some Realism about Nominalism, 60 VA. L. Rev. 451, 477 (1974) ("[T] unnel vision is the priee we pay for avoiding total blindness."). 
That said, courts and legislatures should obtain the best information available, and for many fields of law, economic theory and data will prove useful. To the degree the courts themselves may have inherent expertise in the legal field influenced by economic theory, such as judicial procedure, the process of adaptation is relatively safe, and even relatively new economic theories may be adapted quite successfully. The courts themselves possess the expertise to evaluate the process of adaptation and its potential consequences.

As we move into fields of substantive law, however, the picture becomes murkier. In general, legal disciplines inherently economic in character, such as antitrust, absorb new theories more easily than other fields. Assuming the purpose of the law is reasonably settled, and that the courts have properly examined claims based on network effects, courts and legislatures should have a better idea whether to accept or reject an argument based on network theory than in fields in which economic theory has played a smaller role.

In short, these are not easy questions, and there are no categorical or easy answers. Network economic theories promise to help courts refine legal rules to take account of market structures that do not fit the classical model. But to take advantage of these theories, courts must not blindly accept any argument made under the rubric of "network externality." Rather, they must become adept at separating the wheat from the chaff. We have tried to offer some first steps in that evaluative process. 
CALIFORNIA LAW REVIEW 